WEBER BERINGUI FEITOSA

Proteína quinase C (PKC) e proteína quinase dependente de cálcio/calmodulina (CaMK II) na ativação de oócitos bovinos 


\section{Proteína quinase C (PKC) e proteína quinase dependente de cálcio/calmodulina (CaMK II) na ativação de oócitos bovinos}

Tese apresentada ao Programa de Pós-

Graduação em Reprodução Animal da Faculdade de Medicina Veterinária e Zootecnia da Universidade de São Paulo para obtenção do título de Doutor em Ciências

\section{Departamento:}

Reprodução Animal

Área de Concentração:

Reprodução Animal

Orientadora:

Prof $^{\mathrm{a}}$. Dr ${ }^{\mathrm{a}}$. Mayra Elena Ortiz D’Ávila

Assumpção 
Autorizo a reprodução parcial ou total desta obra, para fins acadêmicos, desde que citada a fonte.

\section{DADOS INTERNACIONAIS DE CATALOGAÇÃO-NA-PUBLICAÇÃO}

(Biblioteca Virginie Buff D’Ápice da Faculdade de Medicina Veterinária e Zootecnia da Universidade de São Paulo)

Feitosa, Weber Beringui

Proteina quinase $\mathrm{C}$ (PKC) e proteina quinase dependente de cálcio/calmodulina

FMVZ (CaMK II) na ativação de oócitos bovinos / Weber Beringui Feitosa. - 2009.

$86 \mathrm{f}$. : il.

Tese (Doutorado) - Universidade de São Paulo. Faculdade de Medicina Veterinária e Zootecnia. Departamento de Reprodução Animal, São Paulo, 2009.

Programa de Pós-Graduação: Reprodução Animal.

Área de concentração: Reprodução Animal.

Orientador: Profa. Dra. Mayra Elena Ortiz D’Ávila Assumpção.

1. PKC. 2. CaMKII. 3. Retículo endoplasmático. 4. Oócito. 5. Bovinos. I. Título. 
FEITOSA, W. B. Proteína quinase C (PKC) e proteína quinase dependente de cálcio/calmodulina (CaMK II) na ativação de oócitos bovinos. [Protein kinase $C$ (PKC) and Calcium/calmodulin-dependent protein kinase II (CaMKII) in bovine oocyte activation]. 2010. 87 f. Tese (Doutorado em Ciências) - Faculdade de Medicina Veterinária e Zootecnia, Universidade de São Paulo, São Paulo, 2010.

$\begin{array}{ccccc}\text { Página } & \text { Parágrafo } & \text { Linha } & \text { Onde se lê } & \text { Leia-se } \\ \text { Resumo } & 1 \underline{\underline{a}} & 4 \underline{\underline{a}} & 87 \mathrm{f} . & 86 \mathrm{f} .\end{array}$




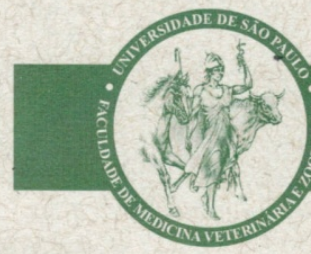

UNIVERSIDADE DE SĀO PAULO

FACULDADE DE MEDICINA VETERINÁRIA E ZOOTECNIA

\section{Comissão de Ética no uso de animais}

\section{CERTIFICADO}

Certificamos que o Projeto intitulado: "Proteína quinase $C(\mathrm{PKC})$ e proteína quinase dependente de cálcio/calmodulina (CaMK II) na ativação de oócitos bovinos", protocolado sob o $\mathrm{n}^{\circ} 1042 / 2007$, utilizando número indefinido de ovário de bovinos (peças de matadouro/ovários), sob a responsabilidade da Profa. Dra. Mayra Elena Ortiz D'Avila Assumpção, está de acordo com os princípios éticos de experimentação animal da "Comissão de Ética no uso de animais" da Faculdade de Medicina Veterinária e Zootecnia da Universidade de São Paulo e foi aprovado em reunião de 07/02/07.

We certify that the Research "Protein kinase C (PKC) and Calcium/calmodulindependent protein kinase II (CaMKII) in bovine oocyte activation", protocol number . 1042/2007, under the responsibility Profa. Dra. Mayra Elena Ortiz D'Avila Assumpção, agree with Ethical Principles in Animal Research adopted by "Ethic Committee in the use of animals" of the School of Veterinary Medicine and Animal Science of University of São Paulo and was approved in the meeting of day $07 / 02 / 07$.

São Paulo, 17 de março de 2010

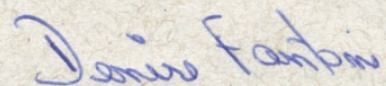

Profa Dra Denise Tabacchi Fantoni

Presidente 


\section{FOLHA DE AVALIAÇÃO}

Nome: FEITOSA, Weber Beringui

Título: Proteína quinase $\mathrm{C}(\mathrm{PKC})$ e proteína quinase dependente de cálcio/calmodulina (CaMK II) na ativação de oócitos bovinos

Tese apresentada ao Programa de Pós-Graduação em Reprodução Animal da Faculdade de Medicina Veterinária e Zootecnia da Universidade de São Paulo para obtenção do título de Doutor em Ciências

Data:

\section{Banca Examinadora}

Prof. Dr. Instituição:

Assinatura: Julgamento:

Prof. Dr. Instituição:

Assinatura: Julgamento:

Prof. Dr. Instituição:

Assinatura: Julgamento:

Prof. Dr. Instituição:

Assinatura: Julgamento:

Prof. Dr. Instituição:

Assinatura: Julgamento: 
Com os pais que tenho

Com o irmão que tenho

Com a família que tenho

Com os amigos que tenho

Com a orientadora que tenho

Com tudo que tenho

Só posso dedicar esta tese à vida

Pela sorte que tenho 
Mayra Elena Ortiz D’Ávila Assumpção Camilla Mota Mendes Pai Marcela Pecora Milazzotto Marcílio Nichi Fabiola Paula Lopes Renata Simões Jose Antonio Visintin Mãe Rafael Fissore FAPESP Camila Infantosi Vanuchi Francesco Silvestre Mariana Groque Marques Chang Li He Marcelo Demarchi Goissis Maria Angélica Peres Pedro Henrique Bugallo Risolio José Sérgio Arruda Gonçalves Mariana Ianello Giassetti Fernanda Sevciuc Maria Everton Lopes Melissa Coney IRMÃO Harumi Doi Shiraishi FMVZ Paulo Varoni Cavalcanti CAPES Dona Sívia Marcia de Almeida Monteiro Melo Ferraz USP Thais Soto Longarço Mariana Ramos Queiroz Takuya Wakai Maíra Bianchi Rodrigues Alves Luís FELIPE ORTIZ Assumpção Padovese Chris Malcuit Julia Maria Baldrighi Adriano Felipe Perez Siqueira Avital Sagalyn Banyoon Cheon Reginaldo da Silva Fontes Vó Claudia Lima Verde Leal Flavia Regina Oliveira de Barros Enrico Sala de Andrade Veerle Vanderheyden Departament o de Reprodução Ani mal Giana Carla Pimentel Saurin Hoi Chang Lee Adaris Matinez Rodrigo Amaral Laura Mota de Oliveira Ana Rita de Sousa Coutinho Sook-Young Yoon Alessandra Coralo Nicacio Maria Alice de Oliveira Samir Saldanha Nicolau Jessíca Espada Rafaela Sabchez Lima 


\section{O velho e o moço}

Deixo tudo assim não me importo em ver

a idade em mim ouço o que convém eu gosto é do gasto

sei do incômodo e ela tem razão quando vem dizer que eu preciso sim de todo o cuidado

e se eu fosse o primeiro a voltar pra mudar o que eu fiz quem então agora eu seria

tanto faz e o que não foi não é eu sei que ainda vou voltar mas eu quem será?

deixo tudo assim não me acanho em ver vaidade em mim eu digo o que condiz eu gosto é do estrago

sei do escândalo e eles tem razão quando vem dizer que eu não sei medir nem tempo e nem medo

e se eu for o primeiro a prever e poder desistir do que for dar errado

olha se não sou eu quem mais vai decidir o que é bom pra mim dispenso a previsão

se o que eu sou é também o que eu escolhi ser aceito a condição

vou levando assim que o acaso é amigo do meu coração quando falo comigo quando eu sei ouvir 


\section{RESUMO}

FEITOSA, W. B. Proteína quinase C (PKC) e proteína quinase dependente de cálcio/calmodulina (CaMK II) na ativação de oócitos bovinos. [Protein kinase $\mathrm{C}$ (PKC) and Calcium/calmodulin-dependent protein kinase II (CaMKII) in bovine oocyte activation]. 2010. 87 f. Tese (Doutorado em Ciências) - Faculdade de Medicina Veterinária e Zootecnia, Universidade de São Paulo, São Paulo, 2010.

A fecundação resulta no aumento intracelular de cálcio que é necessário para a transição do oócito até o estádio de zigoto. Os eventos que ocorrem durante esta transição são caracterizados como ativação, sendo estes dependentes de cálcio. Entretanto, os eventos bioquímicos que ocorrem durante a ativação ainda não estão completamente elucidados. A proteína quinase $\mathrm{C}(\mathrm{PKC})$ e a proteína quinase dependente de cálcio/calmodulina (CaMKII), por apresentarem atividade durante a fecundação e por serem ativadas por cálcio são implicadas na regulação dos eventos da ativação. Entretanto, existem muitas dúvidas sobre o real papel destas proteínas na ativação do oócito. Deste modo, o objetivo do presente trabalho foi avaliar o papel da PKC e da CaMKII na ativação de oócitos bovinos. Para tal, oócitos bovinos maturados in vitro foram ativados partenogeneticamente (AP) com cálcio ionóforo A23187 $(5 \mu \mathrm{M})$ por 5 minutos, sendo a retomada da meiose, a organização do citoesqueleto e do retículo endoplasmático (RE) avaliada 1 hora após a ativação. No experimento 1 foi avaliado o papel da CaMKII nestes eventos. Os oócitos foram AP na presença ou ausência de $100 \mu \mathrm{M}$ do inibidor de CaMKII (Autocamtide-2 Related Inhibitory Peptide, Myristoylated). A inibição da CaMKII não afetou a retomada da meiose e nem a distribuição dos RE, após a AP. Entretanto, não ocorreu a rotação do fuso meiótico no estádio de telófase II quando a CaMKII foi inibidada. Estes resultados demonstram que embora a CaMKII não tenha efeito na retomada da meiose, esta proteína participa na progressão do ciclo celular de oócitos bovinos, após a AP. No experimento 2 foi avaliado o papel da PKC em oócitos bovinos AP. Os oócitos foram ativados partenogeneticamente na presença ou ausência de $10 \mu \mathrm{M}$ do inibidor de PKC (Bisindolymaleimide I). A inibição da PKC não afetou a retomada da meiose e nem a progressão pelo ciclo celular até o estádio de telófase II. Entretanto, a organização do RE foi afetada pela inibição da PKC. Resultado semelhante foi obtido quando os oócitos foram ativados na presença de citocalasina $\mathrm{C}$, um despolimerizador de filamentos de actina. $\mathrm{O}$ presente experimento demonstra a participação da via PKC-actina na organização do RE na ativação de oócitos bovinos.

Palavras-Chave: PKC. CaMK II. Retículo endoplasmático. Oócito. Bovinos. 


\begin{abstract}
FEITOSA, W. B. Protein kinase C (PKC) and Calcium/calmodulin-dependent protein kinase II (CaMKII) in bovine oocyte activation. [Proteína quinase C (PKC) e proteína quinase dependente de cálcio/calmodulina (CaMK II) na ativação de oócitos bovinos]. 2010. 87 f. Tese (Doutorado em Ciências) - Faculdade de Medicina Veterinária e Zootecnia, Universidade de São Paulo, São Paulo, 2010.
\end{abstract}

The intracellular calcium increase resulting from fertilization is necessary for oocyte transition to zygote. The events that occur during this transition are characterized as "activation", which are dependent on calcium. However the biochemical events that occur during this activation are still not fully elucidated. The protein kinase $\mathrm{C}$ (PKC) and the calcium/calmodulin-dependent protein kinase II (CaMKII), are involved in regulating the events of activation, since these proteins have activity during fertilization and are activated by calcium. However there are many doubts about the real role of these proteins in the oocyte activation. Thus, the objective of this study was to evaluate the role of PKC and CaMKII in bovine oocyte activation. For this purpose, in vitro matured bovines oocytes were parthenogenetically activated (PA) by using calcium ionophore A23187 $(5 \mu \mathrm{M})$ for five minutes, and the resumption of meiosis, the cytoskeleton organization and the endoplasmic reticulum (ER) organization were evaluated 1 hour post-activation. In experiment 1 , were evaluated the role of CaMKII in these events. The oocytes were PA in the presence or absence of $100 \mu \mathrm{M}$ of CaMKII inhibitor (Autocamtide-2 Related Inhibitory Peptide, Myristoylated). The inhibition of CaMKII did not affect the meiosis resumption and the ER after the PA. However, there was no spindle rotation at telophase II stage when the CaMKII was inhibited. These results showed that although the CamKII has no effect on resumption of meiosis, it participates in the regulation of cell cycle progression after PA of bovine oocytes. In experiment 2, was evaluated the role of PKC on PA bovine oocytes. The oocytes were parthenogenetically activated in the presence or absence of $10 \mu \mathrm{M}$ of PKC inhibitor (Bisindolymaleimide I). The PKC inhibition did not affected the resumption of meiosis and the progression through the cell cycle until the stage of telophase II. However, the ER organization was affected by PKC inhibition. A similar result was obtained when the oocytes were activated in the presence of cytochalasin $\mathrm{C}$, which promotes the depolymerization of the actin filaments. The current experiment showed the participation of the PKC-actin pathway at the ER organization in the bovine oocytes activation.

Key words: PKC. CaMKII. Endoplasmic reticulum. Oocyte. Bovine. 


\section{LISTA DE FIGURAS}

Figura $1-$

Figura $2-$

Figura 3 -

Figura 4 -

Figura $5-$

Figura $6-$

Figura $7-$

Figura 8 -

Figura $9-$

Figura $10-$

Figura $11-$

Figura $12-$
Modelo hipotético gráfico das possíveis vias da ativação do oócito.

Representação esquemática das estruturas e da classificação das isoformas.

Distribuição dos filamentos de actina em oócitos no estádio de MII e após a ativação partenogenética com ou sem o inibidor de CaMKII (AIP).

Retomada da meiose após a ativação partenogenética com cálcio ionóforo e efeito do inibidor de CaMKII (AIP) sobre a rotação do fuso meiótico.

Distribuição do RE em oócitos no estádio de MII e após a ativação partenogenética com ou sem o inibidor de CaMKII (AIP).

Modelo hipotético gráfico da participação da CaMKII na ativação partenogenética de oócitos bovinos

Organização e distribuição dos microtúbulos nos oócitos em MII e após a ativação partenogenética induzida pelo cálcio ionóforo, tratados ou não com o inibidor de PKC (BIM).

Distribuição dos filamentos de actina em oócito no estádio de metáfase II e após a ativação partenogenética na presença ou ausência do inibidor de PKC (BIM).

Distribuição do RE em oócitos no estádio de MII e após a ativação partenogenética com ou sem o inibidor de PKC (BIM). 57

Efeito da despolimerização dos filamentos de actina na organização do RE

Modelo hipotético gráfico da participação da PKC na ativação partenogenética de oócitos bovinos. 


\section{LISTA DE ABREVIATURAS}

$\mu \mathrm{g}$ - Micrograma;

$\mu \mathrm{L}$ - Microlitro;

AIP - Autocamtide-2 Related Inhibitory Peptide, Myristoylated

BIM - Bisindolylmaleimide I

BSA - Albumina Sérica Bovina

$\mathrm{Ca}^{2+}-$ Cálcio

$\left[\mathrm{Ca}^{2+}\right] \mathrm{i}-$ Cálcio intracelular

CaMK II - Proteína quinase dependente de Calmodulina

CIV - Cultivo in vitro;

$\mathrm{CO}_{2}$ - Dióxido de carbono;

CSF - Fator citostático;

DAG - Diacil glicerol

DNA - Ácido desoxirribonucléico

Emi2 - Inibidor meiótico endógeno

ERM - Esrina, Radixina e Miosina

ERP - Proteína relacionada a Emi2/Emi1

FITC - Isotiocianato de fluoresceína

FE - Fator Espermático

FSH - Hormônio Folículo Estimulante

IP - Fosfolipídio de inositol

$\mathrm{IP}_{3}$ - Inositol trifosfato

LH - Hormônio Luteinizante;

MAPK - Proteína quinase ativada por mitógenos

MARCKS - Substrato de quinase $\mathrm{C}$ rico em alanina miristolada

MIV - Maturação in vitro

$\mathrm{mL}$ - Mililitro

MPF - Fator Promotor da Maturação

MII - Metáfase II

PBS - Tampão fosfato salino

$\mathrm{PIP}_{2}$ - Fosfatidilinositol bifosfato

PLC $\zeta$ - Fosfolipase zeta; 
Plx - Polo quinase

PKC - Proteína quinase C

PVA - Álcool polivinílico

RE - Retículo Endoplasmático

SFB - Soro Fetal Bovino;

SOF - Fluido de oviduto sintético

TCM-199 - Meio de cultura de tecidos 199

VG - Vesícula Germinativa 


\section{SUMÁRIO}

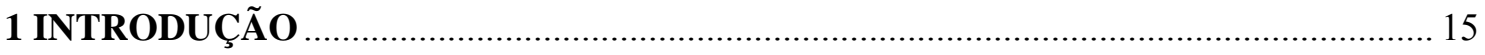

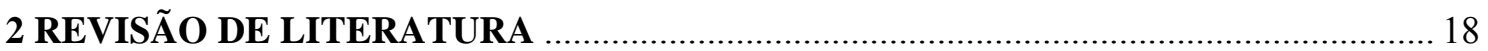

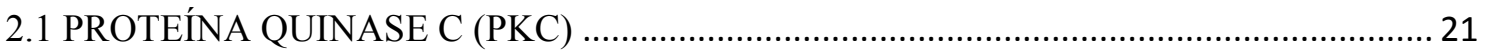

2.2 PROTEÍNA QUINASE DEPENDENTE DE CALMODULINA CaMKII ............................ 24

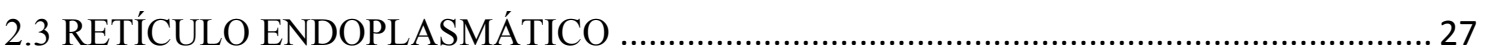

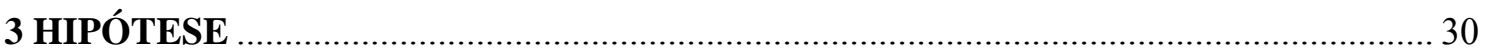

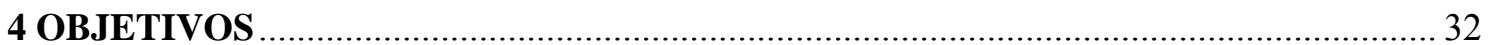

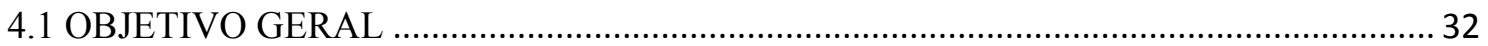

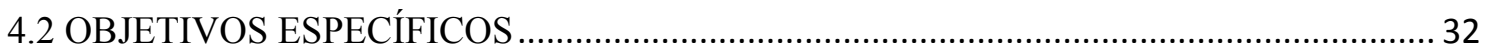

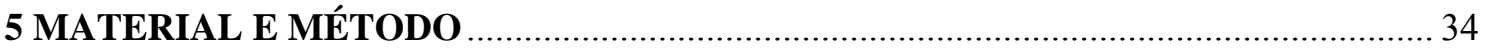

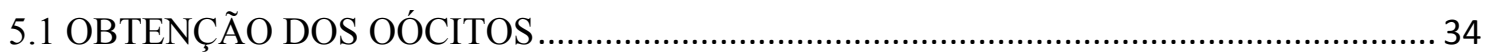

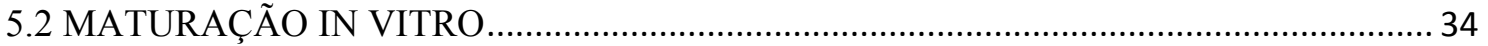

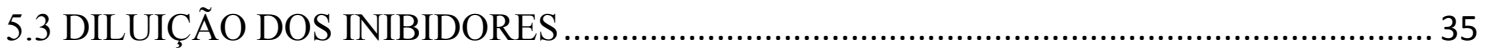

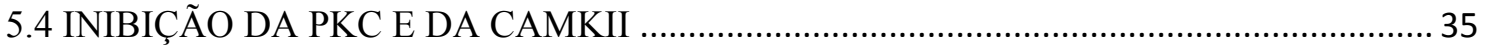

5.5 DESPOLIMERIZAÇÃO DOS MICROFILAMENTOS DE ACTINA ……............................. 35

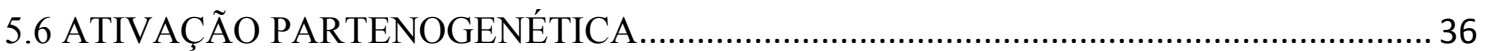

5.7 FIXAÇÃO E PERMEABILIZAÇÃO DOS OÓCITOS E ZIGOTOS …….............................. 36

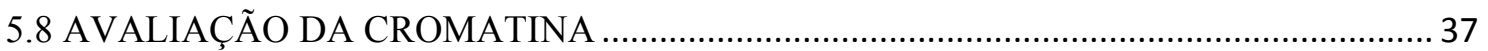

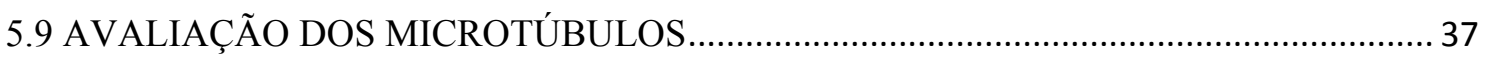

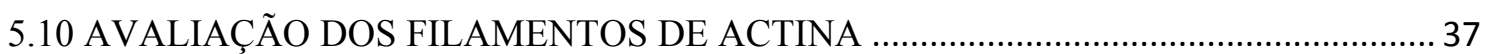

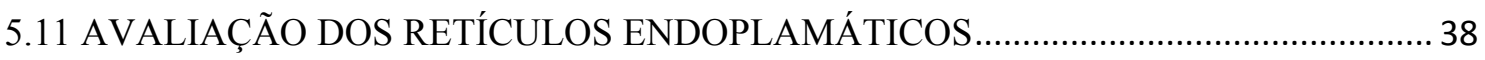

5.12 MONTAGEM DAS LÂMINAS E AVALIAÇÃO DOS OÓCITOS E ZIGOTOS .............. 38

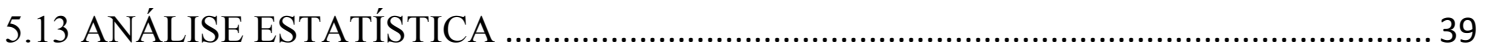

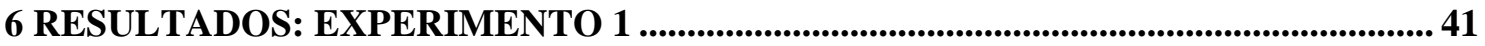

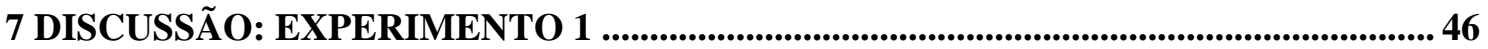

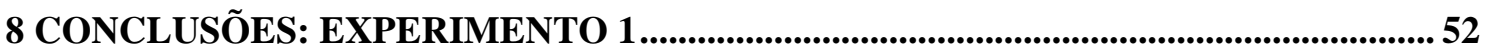

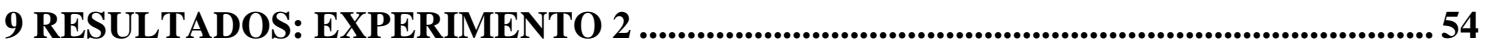

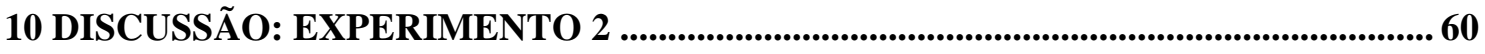

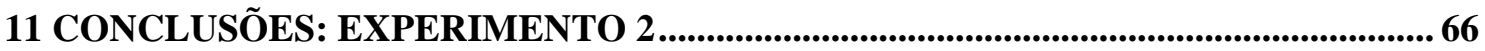

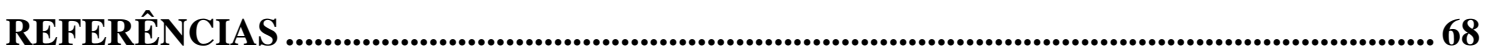

ANEXOS 


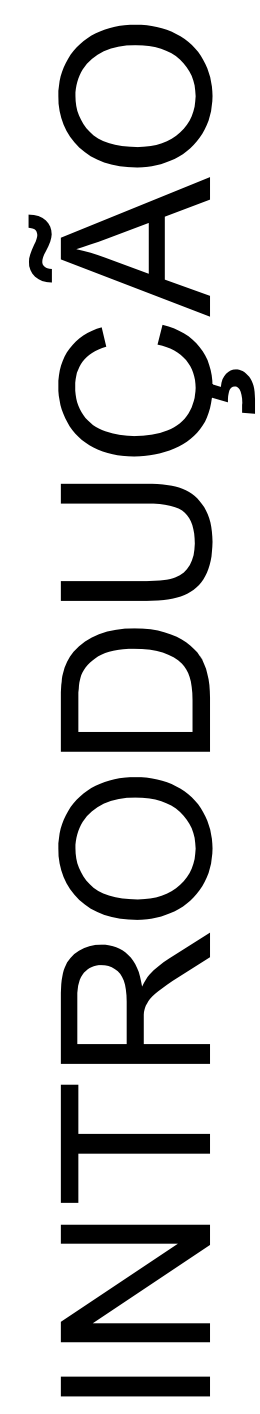




\section{INTRODUÇÃO}

Durante a fecundação ocorre a liberação intracitoplasmática de $\mathrm{Ca}^{2+}$. Uma vez liberado, o $\mathrm{Ca}^{2+}$ inicia um processo de transdução de sinais que desencadeia a ativação do oócito. $\mathrm{O} \mathrm{Ca}^{2+}$ desempenha um papel pivô na fecundação desencadeando todos os eventos da ativação oocitária e o correto padrão de oscilação $\mathrm{Ca}^{2+}$ é fundamental para uma perfeita transição oócito-zigoto-embrião (JONES, 2007).

Os eventos da ativação iniciados em resposta ao aumento da concentração de $\mathrm{Ca}^{2+}$ intracelular $\left[\mathrm{Ca}^{2+}\right]_{\mathrm{i}}$ na fecundação são classificados em eventos iniciais ou tardios da ativação (SCHULTZ; KOPF, 1995). Os eventos iniciais incluem a retomada da meiose e a exocitose dos grânulos corticais. O processo de exocitose é seguido por alterações das glicoproteínas da zona pelúcida e membrana plasmática, estabelecendo deste modo o bloqueio da poliespermia (RAZ; BEN-YOSEF; SHALGI, 1998). Os eventos tardios da ativação incluem a extrusão do segundo corpúsculo polar, a descondensação do núcleo espermático, o recrutamento de RNA materno, a formação de pronúcleo, o início da síntese de DNA e a clivagem (XU et al., 1994; SCHULTS; KOPF, 1995). Entretanto, o efeito destas oscilações de $\mathrm{Ca}^{2+}$ em proteínas específicas e como essas proteínas regulam vários eventos da ativação ainda não está completamente elucidado. Algumas proteínas quinase como a PKC e a CaMKII, por serem ativadas pelo $\mathrm{Ca}^{2+}$, tem sido implicadas na regulação dos eventos da ativação oocitária.

Há evidências de que a PKC participa de importantes eventos da ativação do oócito como a exocitose de grânulos corticais, a saída da metáfase II, a extrusão do corpúsculo polar, a formação do pró-núcleo, a reorganização do citoesqueleto e a formação do fuso meiótico. Contudo, estes mesmos eventos também tem sido descritos como regulados pela CaMKII (DUCIBELA; FISSORE, 2008).

Estas contradições em relação ao exato papel de cada proteína (PKC e CaMKII) pode ser devido aos diferentes agentes ativadores e inibidores utilizados em cada estudo, aos diferentes métodos de ativação partenogenética e também devido às particularidades inerentes a cada espécie animal estudada. Embora exista contradição quanto ao papel que cada uma destas proteínas exerce durante a ativação do oócito, o que se sabe é que tanto a PKC quanto a CaMKII são ativadas durante a fecundação em conseqüência do aumento da concentração de $\left[\mathrm{Ca}^{2+}\right] \mathrm{i}$ (HALET et al., 2004; MADGWICK, 2005). 
$\mathrm{Na}$ tentativa de trazer um pouco mais de conhecimento sobre o papel da PKC e da CaMKII na ativação do oócito em bovinos, surgiu a idéia de se delinear e realizar este trabalho. 


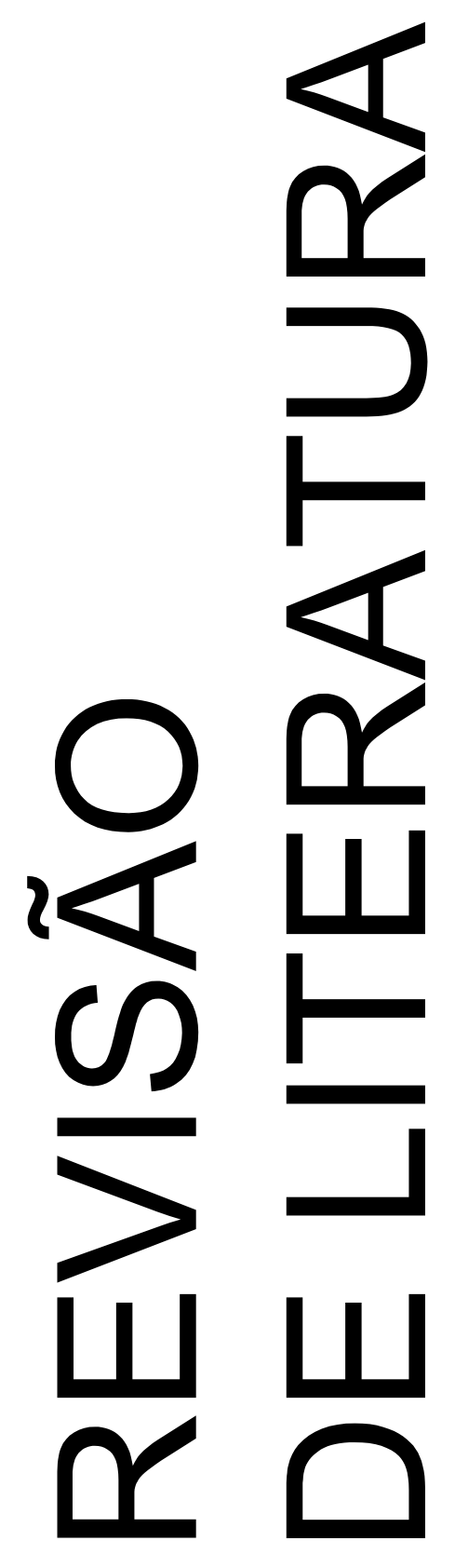




\section{REVISÃO DE LITERATURA}

Oócitos da maioria dos mamíferos são ovulados em metáfase II (MII) e permanecem neste estágio até a fecundação, quando retomam a meiose. A primeira série de eventos que ocorre no oócito é chamada de ativação e inclui a retomada da meiose, a extrusão do segundo corpúsculo polar, a replicação do DNA e a primeira clivagem mitótica (SCHULTZ; KOPF, 1995). O aumento na concentração intracelular de cálcio $\left(\mathrm{Ca}^{2+}\right)$ é o sinal universal responsável pela ativação do oócito, entretanto existem várias hipóteses sobre como ocorre este aumento de $\mathrm{Ca}^{2+}$ na ativação do oócito pelo espermatozóide. Atualmente, a mais aceita é da presença de um fator espermático (FE) (RUNFT et al., 2002), que é introduzido junto com o núcleo do espermatozóide no citoplasma do oócito, sendo este fator o responsável pelas oscilações de $\mathrm{Ca}^{2+}$, após a fecundação.

Experimentos que realizam a microinjeção do extrato espermático contendo o FE, verificaram que este promove a ativação dos oócitos, promovendo oscilações de cálcio semelhante às que ocorrem durante a fecundação em oócitos de camundongos (SWANN, 1996), de bovinos (KNOTT et al., 2002), de suínos (MACHATY et al., 2000) e de eqüinos (BEDFORD et al., 2003). Recentes estudos demonstram que uma nova fosfolipase C (PLC),

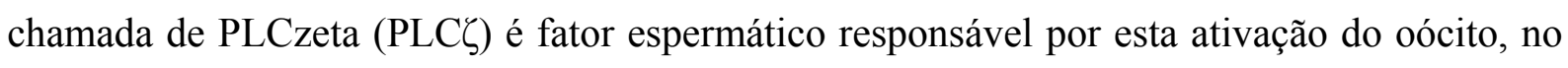
qual a microinjeção da PLCל ou respectivo mRNA provoca oscilações de cálcio semelhantes às que ocorre durante a fecundação (SAUNDERS et al., 2002; KOUCH et al., 2004; KNOTT et al., 2005).

A fosfolipase $\mathrm{C}$ atua no fosfolipídio de inositol (IP) de membrana, catalisando a hidrólise do fosfatidil 4,5-bifosfato $\left(\mathrm{PIP}_{2}\right)$ gerando duas moléculas mensageiras distintas. Há liberação da parte hidrofílica do fosfolipídio e a produção do inositol 1,4,5-trifosfato $\left(\mathrm{IP}_{3}\right)$, enquanto que a cauda do lipídio, o diacilglicerol (DAG), permanece inserido na membrana plasmática. $\mathrm{O} \mathrm{IP}_{3}$ deixa a membrana plasmática e se difunde pelo citoplasma. Quando chega ao retículo endoplasmático, o $\mathrm{IP}_{3}$ se liga a receptores específicos $\left(\mathrm{IP}_{3} \mathrm{R}\right)$, abrindo os canais de $\mathrm{Ca}^{2+}$ do retículo endoplasmático, liberando estes íons para o citoplasma. Uma vez livre no citoplasma há duas possíveis vias pelas quais o $\mathrm{Ca}^{2+}$ atua na ativação do oócito (Figura 1). 


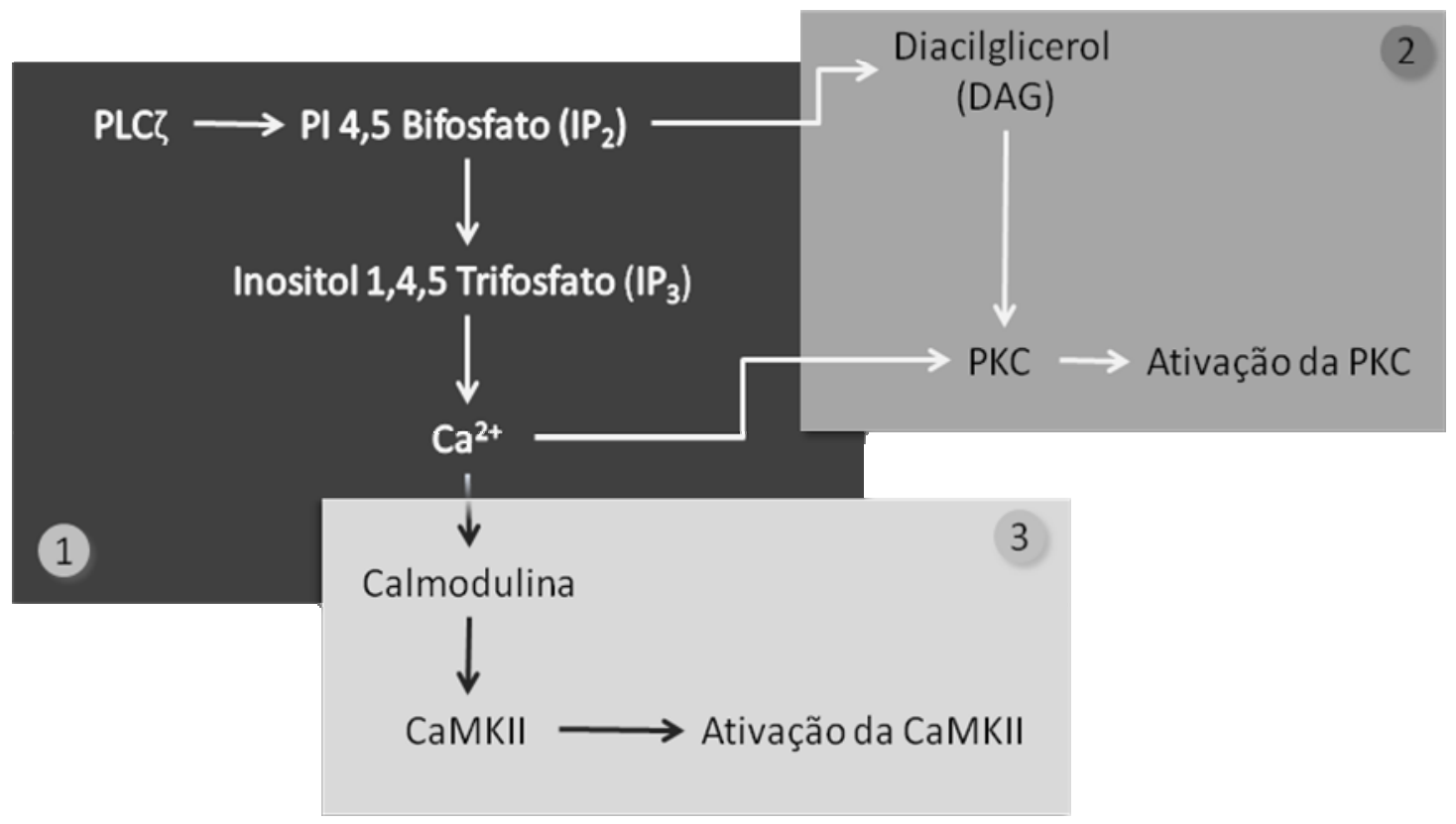

Figura 1 - Modelo hipotético gráfico das possíveis vias da ativação do oócito. 1) Na fecundação, o espermatozóide libera dentro do oócito o fator espermático (FE) contendo a PLC $\zeta$ que causa hidrólise do fosfolipídio de inositol produzindo duas moléculas mensageiras ( $\mathrm{IP}_{3}$ e DAG). O IP $\mathrm{IP}_{3}$ se difunde pelo citosol, se liga aos receptores de $\mathrm{IP}_{3}$, liberando $\mathrm{Ca}^{2+}$ do retículo endoplasmático e o DAG que permanece na membrana plasmática. 2) O DAG juntamente com o $\mathrm{Ca}^{2+}$ ativam a enzima proteína quinase $\mathrm{C}$, que é recrutada do citosol para a face citosólica da membrana plasmática. 3) $\mathrm{O}$ $\mathrm{IP}_{3}$ libera $\mathrm{Ca}^{2+}$ do retículo endoplasmático que modifica a estabilidade conformacional da calmodulina, fazendo com que esta se ligue a CaMKII tornando-a ativa

Durante a fecundação, os oócitos bloqueados no estádio de MII retomam a meiose. Embora seja conhecido que o aumento da $[\mathrm{Ca} 2+] \mathrm{i}$ é necessário para induzir a retomada da meiose, apenas recentemente os mecanismos que regulam este processo têm sido elucidados, sendo descrito o envolvimento do fator promotor de maturação (MPF). O MPF é um heterodímero composto por uma quinase catalítica (p34 $4^{\text {cdc2 }}$ ou CDK1) e uma subunidade de ciclina B regulatória. A atividade de MPF é alta em oócitos no estádio de MII e diminui rapidamente na fecundação (DOREE; HUNT, 2002; JONES, 2004). A diminuição da atividade do MPF durante a fecundação é mediada pelo complexo promotor de anáfase (APC), no qual a atividade é essencial para a retomada da meiose (PETERS, 2006).

Recentemente, uma proteína inibidora do APC chamada de proteína relacionada à Emi2/Emi1 (Erp1), específica para oócitos foi identificada como alvo do aumento do [Ca2+]i, A Erp1 é necessária para prevenir a atividade prematura do APC e, portanto, a retomada da meiose. A Emi2 na fecundação é fosforilada e degradada, sendo este evento promovido pela CaMKII. A atividade da CaMKII aumenta na fecundação em resposta ao aumento da 
concentração de [Ca2+]i (MARKOULAKI et al., 2003; MARKOULAKI; MATSON; DUCIBELLA, 2004), induzindo a degradação da ciclina B1, a inativação da MPF e a retomada da meiose (MADGWICK; LEVASSEUR; JONES, 2005). Deste modo, a via de transdução de sinal básica, que atua na fecundação é conhecida por ser a ativação da APC, pela degradação da Emi2, estimulada pela CaMKII. A ativação da APC induz à degradação da ciclina $\mathrm{B} 1$ e consequentemente à perda da atividade de MPF, levando à retomada da meiose.

Após a fecundação ou a ativação partenogenética de oócitos de camundongos (MOOS et al., 1995), de bovinos (LIU et al., 1998) e de suínos (YAMAUCHI et al., 1998), a atividade do Fator Promotor da Maturação (MPF) diminui rapidamente, enquanto que um longo período é necessário para a diminuição da atividade da Proteína Quinase Ativada por Mitógeno (MAPK). A diminuição da atividade do MPF está envolvida com o início da ativação do oócito (saída da MII) e a diminuição da MAPK está relacionada com a formação dos prónúcleos, evidenciando que a inativação de ambos ocorre por processos independentes (LIU et al., 1998).

As funções celulares da inativação tardia da MAPK não estão muito claras. Já o MPF é inativado rapidamente pela via da degradação dependente do Complexo Promotor de Anáfase (APC), sendo que esta inativação é pré-requisito para a transição da metáfase para a anáfase. Entretanto, o nível de fosforilação e a quantidade da MAPK permanecem estáveis após a ativação do oócito até a formação dos pró-núcleos.

As vias de transdução responsáveis pela ativação do oócito em mamíferos não são completamente entendidas, e perguntas sobre "Qual é o sinal de transdução responsável pela ativação do oócito?" “Como esse mecanismo é regulado?" "Qual o real papel do cálcio?” "Há possibilidade de participação de novos fatores?" ainda não foram respondidas. A literatura é confrontante sobre qual via de sinalização é utilizada pelo oócito após a fecundação, para retomar o ciclo celular. Atualmente a PKC e/ou CaMKII são as proteínas mais cotadas, entretanto o verdadeiro papel destas quinases na ativação do oócito e na diminuição da atividade de MPF e conseqüentemente na retomada da meiose precisa ser melhor estudada. 


\subsection{PROTEÍNA QUINASE C (PKC)}

A PKC foi originalmente identificada como uma proteína quinase dependente de cálcio e fosfolipídio. Entretanto, no mínimo 11 isotipos de PKC foram identificados em mamíferos e classificados em 3 grupos de acordo com a estrutura e característica de ativação: O primeiro grupo foi constituído pela PKCs convencionais (PKC $\alpha, \mathrm{PKC} \beta \mathrm{I}, \mathrm{PKC} \beta \mathrm{II}$ e PKC $\gamma$ ) que são dependentes de cálcio e ativadas pela fosfatidilserina ou pelo diacilglicerol. $\mathrm{O}$ segundo grupo é constituído por PKCs denominadas de "novas" (PKC $\sigma, \mathrm{PKC} \delta, \mathrm{PKC} \varepsilon, \mathrm{PKC} \eta$ e PKC $\theta$ ) que são independente de cálcio, mas também reguladas pela fosfatidilserina ou pelo diacilglicerol; e constituindo o terceiro grupo estão as $\mathrm{PKC}$ denominadas de atípicas (PKC $\zeta$ e $\operatorname{PKC} \lambda)$ que são independente de cálcio e não necessitam de fosfatidilserina nem do diacilglicerol para a ativação (MACKAY; TWELVES, 2007).

$\mathrm{O}$ domínio regulatório da $\mathrm{PKC}$ contém dois módulos conservados; o domínio $\mathrm{C} 1$ e o C2. Diferente das PKCs convencionais, o domínio C2 das PKCs "novas" não possui aminoácidos para a ligação de cálcio, enquanto que as PKCs atípicas não contêm o domínio C2 inteiro e possuem apenas um anel rico em cisteína no domínio C1 (Figura 2) (NISHIZUKA, 1992; NEWTON, 1995; SCHENK; SNAAR-JAGALSKA, 1999; SHIRAI; SAITO, 2002).

O processo de fecundação em mamíferos desencadeia oscilações de $\left[\mathrm{Ca}^{2+}\right] \mathrm{i}$ e a produção de diacilglicerol. Tanto o cálcio quanto o DAG são também ativadores da PKC. Por este motivo a PKC tem sido implicada na regulação dos principais eventos da ativação oocitária relacionados à estrutura desta célula desde a metáfase II (MII) até a formação do zigoto (GALLICANO et al., 1995; YU et al., 2008). 


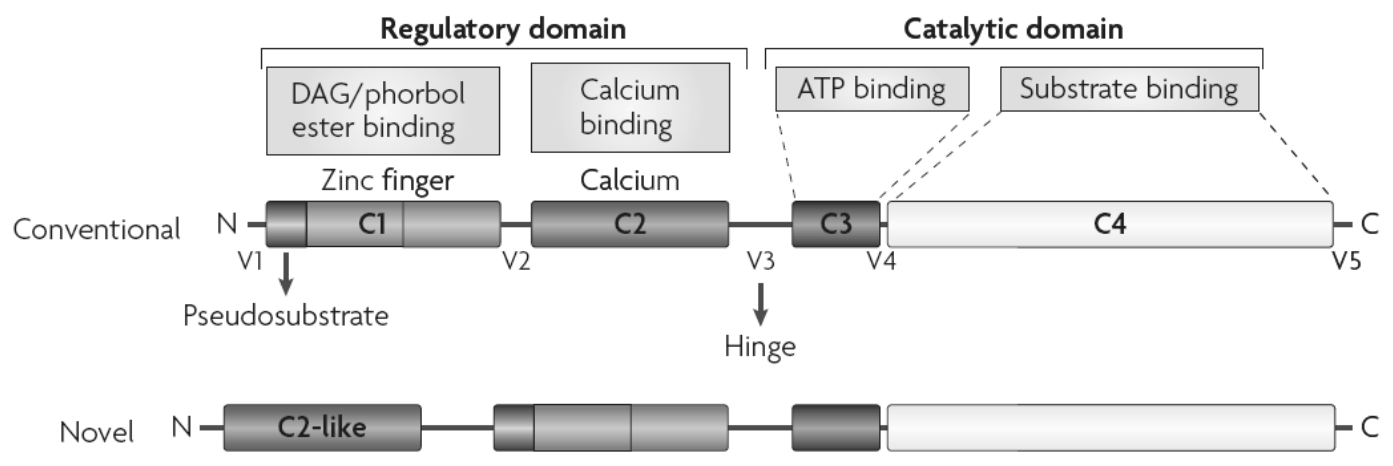

Atypical $N$ C2-like

Fonte: MACKAY; TWELVES, 2007

Figura 2 - Representação esquemática das estruturas e da classificação das isoformas da PKC. A PKC possui 4 domínios conservados (C1-4): $\mathrm{C} 1$ contém 1 ou 2 motifis que formam o sítio de ligação do diacilglicerol e do éster de forbol. C2 contém o sítio para ligação de ácidos lipídicos e de ligação de cálcio. C3 e C4 formam o sítio de ligação de ATP e de substrato da unidade catalítica. O domínio C2 das PKCs novas não possui aminoácidos para a ligação de cálcio. As PKCs atípicas têm somente um motifi rico em cisteína e o sítio de ligação do éster de forbol não foi detectado

Tem sido demonstrado que a atividade da PKC aumenta drasticamente em conseqüência da elevação da concentração de $\mathrm{Ca}^{2+}$ após a fecundação em camundongos (LURIA et al., 2000) e em suínos (FAN et al., 2002). Para que a PKC seja ativada, esta deverá migrar até a membrana plasmática, local onde os domínios $\mathrm{C} 1$ e $\mathrm{C} 2$, desta proteína, interagem, respectivamente, com o DAG e os lipídeos de membrana (OANCEA; MEYER, 1998). A migração da PKC para a membrana plasmática foi descrita na ativação de oócitos de camundongos (GALLICANO; MCGAUGHEY; CAPCO, 1997; LURIA et al., 2000), de ratos (ELIYAHU; SHALGI, 2002) e de suínos (FAN et al., 2002), sendo correlacionada com as oscilações de $\left[\mathrm{Ca}^{2+}\right] \mathrm{i}$ (HALET et al., 2004).

A PKC está associada com vários componentes do citoesqueleto (INAGAKI et al., 1987). Há evidência de haver interação da sinalização citoplasmática com dois dos três componentes principais do citoesqueleto nos oócitos, os microtúbulos e os microfilamentos (CAPCO, 2001), não interagindo com os filamentos intermediários.

Os filamentos de actina têm sido propostos como sendo reguladores da exocitose. Evidências observadas em outros tipos celulares sugerem que estes filamentos de actina associados à membrana plasmática, atuam como uma barreira para a exocitose pela exclusão de vesículas secretórias (BURGOYNE et al., 1989; VITALE et al., 1991; TRIFARO et al., Weber Beringui Feitosa 
1992), sendo que a despolimerização é a primeira etapa na translocação destas para a membrana plasmática (LELKES et al., 1986; SONTAG et al., 1988; MUALLEM et al., 1995).

Os filamentos de actina desempenham importante papel durante a fecundação. São responsáveis pela incorporação do espermatozóide, pela exocitose dos grânulos corticais, pela movimentação do fuso e pela extrusão do corpúsculo polar (CAPCO; TUTNICK; BEMENT, 1992; GALLICANO; MCGAUGHEY; CAPCO, 1992; GALLICANO; MCGAUGHEY; CAPCO, 1995; TERADA; SIMERLY; SCHATTEN, 2000; WANG et al., 2000). Devido ao fato destes microfilamentos possuírem importante papel na dinâmica da fecundação, e de que a PKC promove a reorganização dos filamentos de actina, com conseqüente exocitose de vesículas, nas células somáticas (MUALLEM et al., 1995 TAKASHI 1997; WANG et al., 2000), atribuiu-se a essa proteína quinase a regulação do tráfico de vesículas pelos filamentos de actina durante a fecundação (ELIYAHU; SHALGI, 2002; ELIYAHU et al., 2005).

Como durante a fecundação, as PKCs convencionais migram até a membrana plasmática para se ligarem ao DAG, estas não são implicadas na regulação do microtúbulo na formação do fuso meiótico. Contudo, as PKCs "novas" e atípicas possuem importante papel no controle da dinâmica do fuso durante a ativação de oócitos de mamíferos (LEE et al., 2000; SUN et al., 2001). Em um estudo no qual se realizou imunoprecipitação, Baluch et al. (2004) demonstraram que a PKC $\zeta$ é fortemente associada com $\gamma$-tubulina e ambas encontravam-se associadas ao fuso meiótico. A inibição destas formas de PKC resultou na quebra do fuso (BALUCH et al., 2004). Já a PKC $\delta$ encontra-se associada ao fuso e ao núcleo em zigotos de camundongos (VIVEIROS et al., 2003), no qual a sua distribuição muda de difusa, em oócitos no estádio de MII, para localizada no fuso, após a fecundação (TATONE et al., 2003). Todavia, camundongos knockout para o gene da $\mathrm{PKC} \delta$ continuaram férteis (LEITGES et al., 2001), demonstrando que embora a PKC $\delta$ esteja presente no fuso meiótico na fecundação, sua atividade parece não ser fundamental na regulação deste.

A PKC também está envolvida em pelo menos uma das duas principais proteínas reguladoras do ciclo celular. A ativação farmacológica da PKC pela droga 1-oleoyl-2-acetylsn-glycerol (OAG) provoca a desfosforilação da MAPK e promove a formação de prónúcleos (FAN; SUN, 2004). Este efeito pode ser impedido pelo uso do inibidor de PKC o1oleoyl-2-acetyl (OA), na ativação partenogenética, sugerindo que a ativação da PKC pode induzir a formação pró-nuclear por uma cascata que desfosforila a MAPK em oócitos de camundongos e de ratos (FAN; SUN, 2004). Resultado semelhante também foi observado Weber Beringui Feitosa 
com o ativador de $\mathrm{PKC}$, o forbol 12-miriatae 13 acetato (PMA) na formação dos pró-núcleos em camundongos (SUN et al., 1999; HALET et al., 2004) e na diminuição da atividade da MAPK em camundongos (LU at el., 2002).

Recentemente, Ito et al. (2003) compararam o papel da onda de $\mathrm{Ca}^{2+}$ e da ativação da PKC com a diminuição da atividade do MPF e da MAPK durante a ativação partenogenética de oócitos de suínos. O emprego de concentrações elevadas do cálcio ionóforo diminuiu a atividade do MPF e da MAPK e induziu a formação pró-nuclear. A inibição da PKC com calfostin foi suficiente para inibir a inativação da MAPK e conseqüentemente a formação dos pró-núcleos, após a ativação partenogenética com cálcio ionóforo.

Por sua vez, a ativação da PKC com PMA, sem tratamento prévio com cálcio ionóforo, diminuiu a atividade de MAPK de maneira dose-dependente, mas sem reduzir a atividade do MPF em oócitos de suínos. Deste modo, a ativação partenogenética em oócitos de suínos foi mediada pela inativação do MPF via cálcio-dependente, seguida pela inativação da MAPK, via dependente de PKC. A ativação da PKC induz a exocitose de grânulos corticais, mas não há relatos na literatura de uma ligação direta entre a ativação da PKC e a retomada da meiose (RAZ et al., 1998; JONES, 1998). De fato, a microinjeção de mRNA para a forma constitutivamente ativa da PKC em oócitos de camundongo não foi suficiente para a retomada da meiose (MADGWICK et al., 2005).

\subsection{PROTEÍNA QUINASE DEPENDENTE DE CALMODULINA CaMKII}

Membros da família da proteína quinase dependente de calmodulina (CaMK) são classificados como Serina (ser) ou Threonina (thr) quinase no qual o substrato P (sítio de fosforilação) contém uma ser ou thr. Como diz o próprio nome, a ativação da CaMK é inicialmente dependente da ligação de $\mathrm{Ca}^{2+} /$ calmodulina. Entretanto, em alguns casos elas são capazes de se tornarem independente de $\mathrm{Ca}^{2+} /$ calmodulina após a ativação ou necessitam de modificação adicional como a fosforilação por outros reguladores para alcançarem uma ativação completa. A CaMK possui um domínio catalítico bi-lobado seguido por um domínio regulatório contendo tanto o domínio auto-inibitório quanto o domínio de ligação da calmodulina (GRIFFITH; 2004). 
A família da CaMK é dividida em duas classes: CaMK multifuncional (CaMKK, CaMKI, CaMKII e CaMKIV), na qual cada uma possui múltiplos alvos e; substrato específico (CaMKIII, Quinase fosforilase e MLCK) que possuem apenas um alvo específico. A CaMKII (Figura 3), por mediar diversas respostas fisiológicas em resposta ao aumento intracelular de $\mathrm{Ca}^{2+}$, tem sido implicada com a principal CaMK envolvida na ativação do oócito. Isto ocorre devido a sua capacidade de ativação por $\mathrm{Ca}^{2+} /$ calmodulina e por modular diversas funções como regulação de canais iônicos, da exocitose e do citoesqueleto (COLBRAN, 2004).

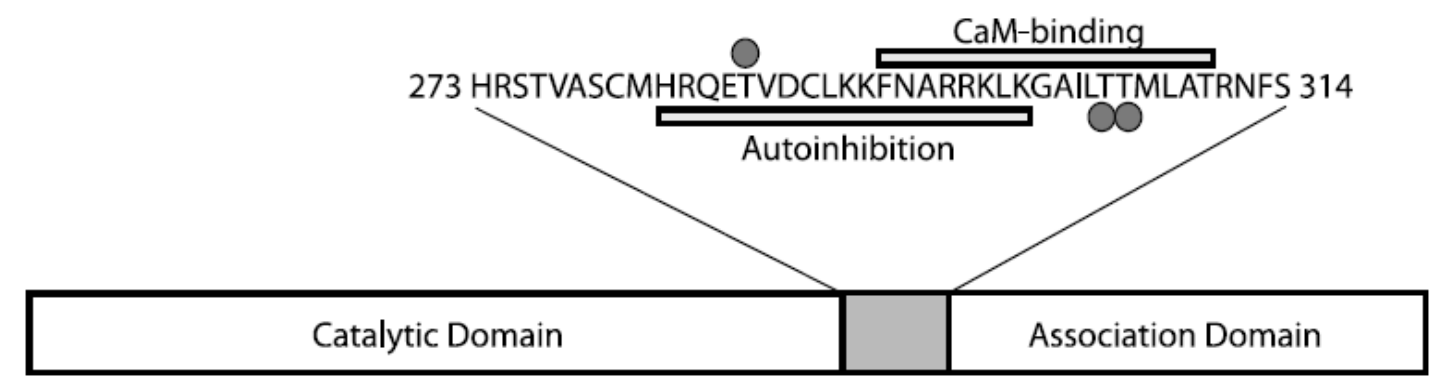

Fonte: GRIFFITH; 2004

Figura 3 - Esquema da estrutura da CaMKII. Todos os isotipos da CaMKII contém um domínio catalítico Nterminal, um domínio regulador interno, e um domínio C-terminal. O domínio regulatório, da seqüência, descrito na parte superior do diagrama é bipartido. A parte proximal do domínio (AA 282300) contém resíduos que interagem com o domínio catalítico para inibir a atividade de fosfotransferase (indicado pela barra abaixo da seqüência). A porção distal deste domínio (AA 293310) se liga ao $\mathrm{Ca}^{2+} /$ calmodulina (indicado pela barra acima da seqüência). Os sítios de fosforilação regulatório na $\mathrm{Thr}^{286}$, $\mathrm{Thr}^{305}$, e $\mathrm{Thr}^{306}$ estão indicados por círculos

Corroborando com o papel da CaMK na ativação do oócito está o fato de a CaMKII estar presente em oócitos de várias espécies (BAITINGER et al., 1990; LORCA et al., 1993; JOHNSON et al., 1998) e sua atividade aumentar durante a fecundação ou a ativação partenogenética (WINSTON; MARO, 1995; WINSTON et al., 1995; JOHNSON et al., 1998; TATONE et al., 2002; MARKOULAKI et al., 2003; MARKOULAKI; MATSON; DUCIBELLA, 2004) com pulsos de atividade em respostas às oscilações de $\left[\mathrm{Ca}^{2+}\right] \mathrm{i}$ (MARKOULAKI; MATSON; DUCIBELLA, 2004).

A inibição da CaMKII bloqueou a saída da Metáfase II em oócitos de camundongos ativados por cálcio (JOHNSON et al., 1998), etanol (WINSTON; MARO, 1995) ou pela fecundação (TATONE et al., 2002). Resultado semelhante foi observado em oócitos de suínos, após a ativação (FAN et al., 2003). Confirmando a participação da CaMKII na retomada da meiose, a microinjeção de CaMKII constitutivamente ativa em oócitos de Weber Beringui Feitosa 
Xenopus e do respectivo mRNA em oócitos de camundongos promoveu a retomada da meiose e a degradação da ciclina, mesmo na ausência de $\mathrm{Ca}^{2+}$ (LORCA et al., 1993; MADGWICK et al., 2005).

O fator promotor de maturação/mitose (MPF), um heterodímero composto por uma unidade catalítica chamada de $\mathrm{p} 34^{\mathrm{cdc} 2}$ e uma unidade reguladora chamada de ciclina B tornase ativo quando a ciclina $\mathrm{B}$ se liga à $\mathrm{p} 34^{\mathrm{cdc} 2}$, promovendo a desfosforilação e torna-se inativo quando ocorre a degradação da ciclina B. Em oócitos de camundongos e de suínos, durante a fecundação ou a ativação partenogenética há estímulo para a degradação da ciclina $\mathrm{B}$. A degradação da ciclina B é evitada pela inibição da CaMKII (WINSTON et al., 1995; JOHNSON et al., 1998; TATONE et al., 2002; FAN et al., 2003). O mesmo pode ser descrito em oócitos de Xenopus, no qual a onda de cálcio induzida durante a fecundação ativa a CaMquinase, que estimula a degradação da ciclina $\mathrm{B}$ pela via da ubiquitina, resultando na inativação da quinase $\mathrm{p} 34^{\mathrm{cdc} 2}$ (WATANABE et al., 1991).

De fato, o aumento da atividade de $\left[\mathrm{Ca}^{2+}\right]$ i promove a retomada da meiose durante a fecundação pela regulação da atividade de MPF (degradação da ciclina) mediada pelo complexo promotor de anáfase (APC) (NIXON et al., 2002). Recentemente, três grupos relataram que a inibição do (APC) pela Emi2 é sustentada pela CaMKII e pela Plx1 de maneira dose dependente (LIU; MALLER, 2005; RAUH et al., 2005; HANSEN et al., 2006). A CaMKII fosforila a Emi2, permitindo a ligação da Plx1, que por sua vez gera uma segunda fosforilação na Emi2. Esta segunda fosforilação promove a degradação da Emi2, reduzindo a inibição do APC, permitindo a retomada da meiose.

A CaMKII também participa da regulação do citoesqueleto na formação do fuso ou segregação do cromossomo (FAN et al., 2003) apresentando forte associação com o fuso meiótico, imediatamente após a ativação, passando a localizar-se nos microtúbulos entre a anáfase II e a telófase II (JOHNSON et al., 1998). Embora seja descrito que a CaMKII regule os filamentos de actina em células somáticas (XX), na fecundação, de acordo com os experimentos realizados por Knott et al. (2006) e por Gardner et al. (2007) essa proteína parece não exercer esse papel. Ao microinjetarem mRNA para CaMKII constitutivamente ativa em oócitos de camundongos não houve indução de migração dos grânulos corticais e nem bloqueio da poliespermia, Como se sabe que amigração dos grânulos corticais durante a fecundação é organizada pelos filamentos de actina (ELIYAHU et al., 2005), presume-se que há uma ausência da regulação dos filamentos de actina pela CaMKII durante esta etapa. 


\subsection{RETÍCULO ENDOPLASMÁTICO}

O retículo endoplasmático (RE) é uma organela multifuncional e altamente dinâmica que esta envolvida na síntese de lipídeos e proteínas e na regulação da homeostase do cálcio. Durante a maturação, o RE sofre reorganização, ou seja, no estádio de vesícula germinativa, o RE encontra-se na região medular do citoplasma em oócitos de camundongos (MEHLMANN et al., 1995; FITZHARRIS; MARANGOS; CARROLL, 2007) ou na região cortical em oócitos de hamster (SHIRAISHI et al., 1995). Na retomada da meiose, durante a quebra da vesícula germinativa, o RE forma um denso anel no centro do oócito ao redor do núcleo (MEHLMANN et al., 1995; SHIRAISHI et al., 1995; FITZHARRIS; MARANGOS; CARROLL, 2007). O RE continua se reorganizando durante a progressão da meiose, migrando junto com o fuso meiótico para a região cortical do oócito no estádio de metáfase II. Como o retículo endoplasmático (RE) é a principal fonte de $\mathrm{Ca}^{2+}$ em oócitos, esta reorganização parece ser essencial para o estabelecimento adequado das oscilações de $\left[\mathrm{Ca}^{2+}\right] \mathrm{i}$ durante a ativação (artigo em elaboração) ${ }^{1}$.

Dependendo da espécie, o RE também sofre profunda reorganização durante a fecundação. Em oócitos de ouriço do mar, a rede cortical do RE, logo após a entrada do espermatozóide (30 segundos) sofre alterações que resultam em fragmentação desta rede, que volta à conformação original (oócito não fecundado) depois 5 a 10 minutos (TERASAKI; JAFFE, 1991).

O mesmo fenômeno pode ser observado em oócitos de starfish (JAFFE; TERASKAI, 1994). Em oócitos de Xenopus também é observada uma rápida reorganização do RE durante a fecundação, porém sem fragmentação da rede de RE (TERASAKI; RUNFT; HAND, 2001). O que ocorre nesta espécie é a desagregação do "cluster" (agrupamento) de RE durante a fecundação, que diferentemente do que ocorre em ouriço do mar e no starfish, não retornam à posição original, encontrada em oócitos não fecundados (TERASAKI; RUNFT; HAND, 2001).

Diferentemente do que ocorre em oócitos de ouriço do mar, starfish e Xenopus, em camundongos não foi observada esta rápida reorganização do RE (MEHLMAN et al., 1995). Entretanto os "clusters" de RE desagregam aproximadamente entre 3 a 4 horas após a fecundação (FITZHARRIS; MARANGOS; CARROLL, 2003), aproximadamente 2 horas

\footnotetext{
${ }^{1}$ FEITOSA, W.B. Reorganização do RE na maturação de oócitos de camundongos. Em elaboração Weber Beringui Feitosa
} 
antes do término das oscilações de $\left[\mathrm{Ca}^{2+}\right]$ i (JONES et al., 1995). Após a desagregação, o RE perde a capacidade de se agregar durante a progressão do ciclo celular e o início da clivagem (FITZHARRIS; MARANGOS; CARROLL, 2003), sugerindo que a desagregação do RE e importante para o término das oscilações de $\left[\mathrm{Ca}^{2+}\right]$ i.

Em bovinos, a organização da proteína calreticulina (proteína do RE associada à liberação de cálcio) em oócitos em MII, encontra-se distribuída pelo citoplasma em forma de “cluster" (PAYNE; SCHATTEN, 2003). De forma semelhante ao zigoto de camundongo, o RE em oócitos de bovino, avaliado por sua proteína calreticulina não sofre reorganização após a fecundação (PAYNE; SCHATTEN, 2003). Entretanto, a proteína Sec 23 (proteína do RE associada à exocitose de vesículas), que se encontra distribuída pelo citoplasma em oócitos no estádio de metáfase II, sofre reorganização após a fecundação passando a se localizar na região cortical após a fecundação (PAYNE; SCHATTEN, 2003). O motivo da reorganização do RE assim como os mecanismos que a regulam não são muito claro.

Aparentemente, a reorganização e/ou fragmentação do RE pode facilitar a migração do pró-núcleo de maneira similar a quebra do envelope nuclear espermático (TERASKAI; JAFFE, 1991). Adicionalmente, a reorganização do RE parece estar associada ao padrão de oscilação de cálcio de cada espécie. Em oócitos de equinodermes, espécie que apresenta um único pico de $\left[\mathrm{Ca}^{2+}\right] \mathrm{i}$, o RE é reorganizado rapidamente após a fecundação. Por outro lado, em oócitos de mamíferos, que possuem picos repetitivos de $\left[\mathrm{Ca}^{2+}\right] \mathrm{i}$ (oscilações), na fecundação, o RE não sofre rápida reorganização. Isto sugere que o padrão do sinal de cálcio pode estar relacionado à estabilidade e/ou reorganização do RE (STRICKER, 1999; KLINE, 2000).

Todos os eventos envolvidos na ativação do oócito são um complexo mecanismo bioquímico, molecular e celular, que envolvem uma extensa rede de sinalização regulada por várias proteínas. As vias de transdução responsáveis pela ativação do oócito em mamíferos não são completamente entendidas. Muitas dúvidas sobre os sinais de transdução na ativação do oócito, mecanismos de regulação destas vias, mecanismo pelo qual o $\mathrm{Ca}^{2+}$ ativa o oócito e até a possível existência de novos fatores ainda existem. A literatura é confrontante sobre qual via de sinalização é utilizada pelo oócito após a fecundação, na regulação dos eventos da ativação e qual a real função de cada uma dessas vias. Atualmente a PKC ou a CaM-quinase são consideradas proteínas chave na regulação destes eventos, embora a literatura também seja confrontante em relação à participação destas proteínas na ativação oocitária. Desta forma o presente trabalho se propõe a estudar o papel destas proteínas na ativação de oócitos bovinos 


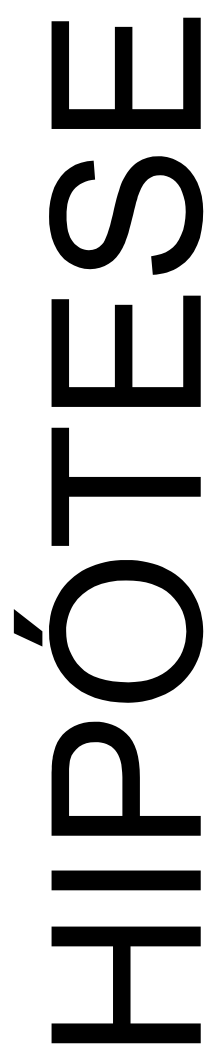




\section{HIPÓTESE}

A PKC e a CaMKII participam na regulação dos mecanismos de ativação de oócitos bovinos em diferentes vias de sinalização que regulam eventos distintos. 


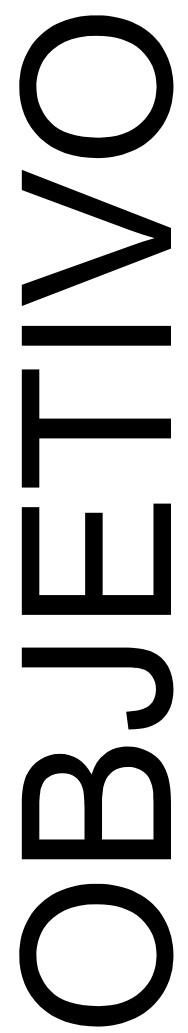




\section{OBJETIVOS}

Para confirmar a hipótese, os objetivos desta tese foram:

\subsection{OBJETIVO GERAL}

Avaliar a função da PKC e da CaMKII na ativação de oócitos bovinos

\subsection{OBJETIVOS ESPECÍFICOS}

- Avaliar a função da PKC e da CaMKII na retomada da meiose

- Avaliar a função da PKC e da CaMKII na regulação do citoesqueleto

- Avaliar a função da PKC e da CaMKII na organização do retículo endoplasmático 


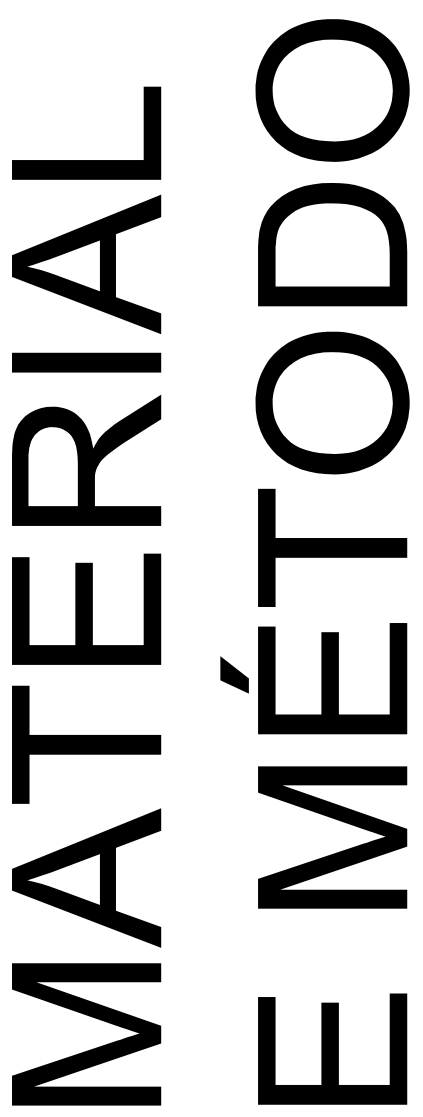




\section{MATERIAL E MÉTODO}

Para a realização deste trabalho, o material método está descrito nos itens a seguir.

\subsection{OBTENÇÃO DOS OÓCITOS}

Os ovários foram obtidos de fêmeas bovinas abatidas em frigorífico comercial e transportados em recipiente térmico contendo solução fisiológica, aquecida a $30^{\circ} \mathrm{C}$. No laboratório, os ovários foram lavados em solução fisiológica aquecida a $30^{\circ} \mathrm{C}$, acrescida de 50 $\mu \mathrm{g} / \mathrm{ml}$ gentamicina.

Os oócitos foram obtidos com auxílio de bisturi e pinça hemostática, em béquer de vidro contendo $50 \mathrm{~mL}$ de meio de fatiamento (TCM 199 Hepes suplementado com 1\% (v/v) de SFB e $50 \mu \mathrm{g} / \mathrm{ml}$ gentamicina - Anexo A). Para tanto, os folículos com diâmetro de 2 a 8 $\mathrm{mm}$ foram fixados com pinça hemostática e incisados com lâmina de bisturi, sendo o líquido folicular recolhido no bécker. Ao término das incisões de cada ovário, o mesmo foi agitado no meio de lavagem, para melhor recuperação do conteúdo folicular. O meio de lavagem contendo o líquido folicular de todos os ovários incisados foi transferido para um tubo de centrífuga de $50 \mathrm{~mL}$, que permaneceu em banho-maria à $37^{\circ} \mathrm{C}$ por 15 minutos para sedimentação dos complexos cumulus oophorus (CCOs). Após este período, o sedimento foi lavado em filtro de nylon de $100 \mu \mathrm{m}$ (BD) e o material retido foi transferido pra uma placa de petri de $100 \mathrm{~mm}$, para recuperação e posterior avaliação dos oócitos, sob estereomicroscópio.

\subsection{MATURAÇÃO IN VITRO}

Os oócitos classificados como graus I e II (contendo três ou mais camadas de células do cumulus oophorus e citoplasma uniforme) foram lavados três vezes em meio de lavagem (TCM 199 Hepes suplementado com 10\% (v/v) de SFB, $22 \mu \mathrm{g} / \mathrm{ml}$ de piruvato e $50 \mu \mathrm{g} / \mathrm{ml}$ gentamicina - Anexo A) seguido por três lavagens em meio de maturação (TCM 199 
suplementado com 10\% (v/v) de SFB, $0,5 \mu \mathrm{g} / \mathrm{ml}$ de FSH, $5 \mu \mathrm{g} / \mathrm{ml}$ de hCG, $1 \mu \mathrm{g} / \mathrm{ml}$ de E$_{2}$, $22 \mu \mathrm{g} / \mathrm{ml}$ de piruvato e $50 \mu \mathrm{g} / \mathrm{ml}$ de gentamicina - Anexo A). Após as lavagens, 20 a 30 oócitos foram colocados em gotas de $90 \mu \mathrm{L}$ de meio de maturação, sob óleo mineral e foram maturados in vitro por 24 horas a $38,5^{\circ} \mathrm{C}$ em atmosfera de $5 \%$ de $\mathrm{CO}_{2}$ em ar e alta umidade.

\subsection{DILUIÇÃO DOS INIBIDORES}

O inibidor de PKC "Bisindolylmaleimide I" (BIM) foi diluído em dimetilsulfóxido na concentração de $10 \mathrm{mM}$ (Anexo B). O inibidor da CaMKII "Autocamtide-2 Related Inhibitory Peptide, Myristoylated” (AIP) foi diluído em água ultrapura (Milli -Q) na concentração de $1 \mathrm{mM}$ (Anexo B). Após a diluição, os inibidores foram aliquotados em tubos de microcentrífuga e armazenados a $-20^{\circ} \mathrm{C}$.

\subsection{INIBIÇÃO DA PKC E DA CAMKII}

Ao término da maturação, as células do cúmulus foram removidas enzimaticamente com $0,1 \%(\mathrm{p} / \mathrm{v})$ de hialuronidase por 10 minutos e mecanicamente com auxílio de pipeta automática. Após a remoção das células do cúmulus, os oócitos, previamente à ativação partenogenética foram incubados por 30 minutos em meio SOFaa suplementado com $10 \mu \mathrm{M}$ do inibidor (BIM) ou sem inibidor (grupo controle), nos experimentos nos quais foi avaliada a função da PKC; ou na ausência (controle) ou suplementado com $100 \mu \mathrm{M}$ do inibidor AIP ou sem inibidor (grupo controle), nos experimentos nos quais foi estudada a função da CaMKII.

\subsection{DESPOLIMERIZAÇÃO DOS MICROFILAMENTOS DE ACTINA}

Ao término da maturação, as células do cúmulus foram removidas enzimaticamente com $0,1 \%(\mathrm{p} / \mathrm{v})$ de hialuronidase por 10 minutos e mecanicamente com auxílio de pipeta 
automática. Após a remoção das células do cúmulus, os oócitos, previamente à ativação partenogenética foram incubados por 30 minutos em meio SOFaa suplementado com citocalasina B $(5 \mu / \mathrm{mL})$. Após este período, os oócitos foram ativados partenogeneticamente e cultivados por 1 hora em SOFaa suplementado com citocalasina B $(5 \mu / \mathrm{mL})$.

\subsection{ATIVAÇÃO PARTENOGENÉTICA}

Após a incubação por 30 minutos com ou sem a suplementação dos inibidores BIM ou AIP, os oócitos foram ativados partenogeneticamente com cálcio ionóforo A23187 $(5 \mu \mathrm{M})$ por 5 minutos (Anexo C). Após a ativação, os oócitos foram lavados 3 vezes em meio SOFaa (Anexo C)e cultivados in vitro por 1 hora, no mesmo meio, suplementado com $10 \mu \mathrm{M}$ de BIM ou não (grupo controle), nos experimentos no qual foi avaliada a função da PKC ou por 1 hora com $100 \mu \mathrm{M}$ do inibidor AIP ou sem (grupo controle), nos experimentos no qual foi estudada a função da CaMKII.

\subsection{FIXAÇÃO E PERMEABILIZAÇÃO DOS OÓCITOS E ZIGOTOS}

Os oócitos no estádio de MII e os zigotos ativados com ou sem inibidores de PKC (BIM) ou de CaMKII (AIP) foram fixados em 3,7\% (v/v) de formaldeído por 30 minutos (Anexo D). Após a fixação, os oócitos foram lavados três vezes em PBS (tampão fosfato salina, livre de cálcio e magnésio), acrescido de $0,1 \%(\mathrm{p} / \mathrm{v})$ de PVA (álcool polivinílico) (Anexo D). Ao término das três lavagens, oócitos e zigotos foram permeabilizados por 5 minutos com $0,1 \%(\mathrm{v} / \mathrm{v})$ de triton X-100 diluído em PBS suplementado com $0,1 \%$ de PVA (Anexo D), sendo posteriormente lavados 3 vezes em PBS, acrescido de $0,1 \%(\mathrm{p} / \mathrm{v})$ de PVA. 


\subsection{AVALIAÇÃO DA CROMATINA}

Para a avaliação da configuração nuclear, os oócitos e zigotos foram incubados por 10 minutos em PBS acrescido de 0,1\% (p/v) de PVA, contendo $10 \mu \mathrm{g} / \mathrm{ml}$ de Hoechst 33342, diluído em glicerol (Anexo D). As estruturas foram avaliadas em lâminas que foram confeccionadas conforme descrito detalhadamente no item 5.12, sob microscopia de epifluorescência.

\subsection{AVALIAÇÃO DOS MICROTÚBULOS}

Os oócitos e os zigotos foram bloqueados em PBS sem cálcio e magnésio, suplementado com $5 \%$ de soro de cabra (v/v) por 30 minutos (Anexo D). Após o bloqueio, os oócitos e zigotos foram incubados por 1 hora com o anticorpo primário de camundongo antialfa-tubulina bovina (Invitrogen, Carlsbad, California, EUA - A11126). O anticorpo primário foi diluído $(1: 100 ; \mathrm{v} / \mathrm{v})$ em PBS sem cálcio e magnésio, suplementado com $5 \%$ de soro de cabra (v/v). Ao término da incubação, oócitos e zigotos foram lavados 3 vezes em PBS sem cálcio e magnésio, suplementado $5 \%$ de soro de cabra $(\mathrm{v} / \mathrm{v})$ e incubados por mais 1 hora com o anticorpo secundário de coelho anti-IgG de camundongo Alexa Fluor 568 (Invitrogen, Carlsbad, California, EUA - A11031), sendo este diluído1:200; v/v em PBS sem cálcio e magnésio, suplementado com $5 \%$ de soro de cabra $(\mathrm{v} / \mathrm{v})$. Após este período, as estruturas foram lavadas 3 vezes em PBS sem cálcio e magnésio suplementado com $5 \%$ de soro de cabra $(\mathrm{v} / \mathrm{v})$. As estruturas foram avaliadas em lâminas que foram confeccionadas conforme descrito detalhadamente no item 5.12., sob microscopia de epifluorescência.

\subsection{AVALIAÇÃO DOS FILAMENTOS DE ACTINA}

Para a avaliação dos filamentos de actina, oócitos e zigotos foram fixados e permeabiliazados e incubados com $120 \mu \mathrm{L}$ da toxina faloidina conjugada com alexa fluor 568 
(Invitrogen, Carlsbad, California, EUA - A12380), por 1 hora. Ao término da incubação, oócitos e zigotos foram lavados três vezes em PBS sem cálcio e magnésio suplementado com $5 \%$ de soro de cabra $(\mathrm{v} / \mathrm{v})$. As estruturas foram avaliadas em lâminas que foram confeccionadas conforme descrito detalhadamente no item 5.12., sob microscopia de epifluorescência.

\subsection{AVALIAÇÃO DOS RETÍCULOS ENDOPLAMÁTICOS}

Para avaliar o efeito da PKC e da CaMKII na distribuição do RE, os oócitos e os zigotos foram bloqueados com PBS sem cálcio e magnésio suplementado com 5\% de soro de cabra (v/v), por 30 minutos. Ao término da incubação, oócitos e zigotos foram incubados por 1 hora com o anticorpo primário de coelho anti-retículo (PDI) (abcam, Cambridge, Massachusetts, EUA - AB3672), utilizando a diluição 1:100 (v/v) em PBS sem cálcio e magnésio suplementado com 5\% de soro de cabra. Após a incubação, oócitos e zigotos foram lavados três vezes em PBS sem cálcio e magnésio suplementado com $5 \%$ de soro de cabra (v/v) e incubados com o anticorpo secundário de jumento anti-IgG de coelho (Santa Cruz Biotechnolohy, Santa Cruz, Califórnia, EUA - SC-2090). Para diluir o anticorpo secundário foi utilizado PBS sem cálcio e magnésio suplementado com 5\% de soro de cabra 1:200; v/v por 1 hora. Após este período, as estruturas foram lavadas três vezes em PBS sem cálcio e magnésio suplementado com $5 \%$ de soro de cabra (v/v). Os oócitos e os zigotos foram avaliados em lâminas que foram confeccionadas conforme descrito detalhadamente no item 5.12., sob microscopia de epifluorescência.

\subsection{MONTAGEM DAS LÂMINAS E AVALIAÇÃO DOS OÓCITOS E ZIGOTOS}

Após a imunofluorescência e/ou marcação com as sondas fluorescentes, os oócitos ou os zigotos foram agrupados $(\mathrm{n}=5)$ e colocados em $10 \mu \mathrm{L}$ de DABCO (Anexo D) sobre lâmina. A lamínula foi previamente marcada com parafina nas extremidades e as estruturas foram 
comprimidas entre lâmina e lamínula com uma leve pressão nas extremidades da lamínula, sendo então realizado vedação com esmalte de unha comum.

A avaliação da cromatina, dos microtúbulos, dos filamentos de actina e do RE foi realizada sob microscópio de epifluorescência, utilizando filtros com 355, 490 e 520nm de excitação e 465, 552 e 610nm de emissão, para as fluorescencias azul, vermelha e verde, respectivamente.

\subsection{ANÁLISE ESTATÍSTICA}

A avaliação da organização dos filamentos de actina, de tubulina e o retículo endoplasmático foi feita por microscopia de epifluorescência e a intensidade da fluorescência emitida pelos oócitos e zigotos foi quantificada pelo programa image J (Maryland, USA). Os dados de intensidade de fluorescência capturados pelo programa foram avaliados utilizando o procedimento PROC GLM do programa Statistical Analysis System, versão 9.1.3 (SAS, 1995), sendo posteriormente utilizado o teste t Student, com nível de significância de 5\%. Foram realizadas cinco replicatas por tratamento, com uma média de 20 oócitos por replicata ( $n=100$ oócitos). 


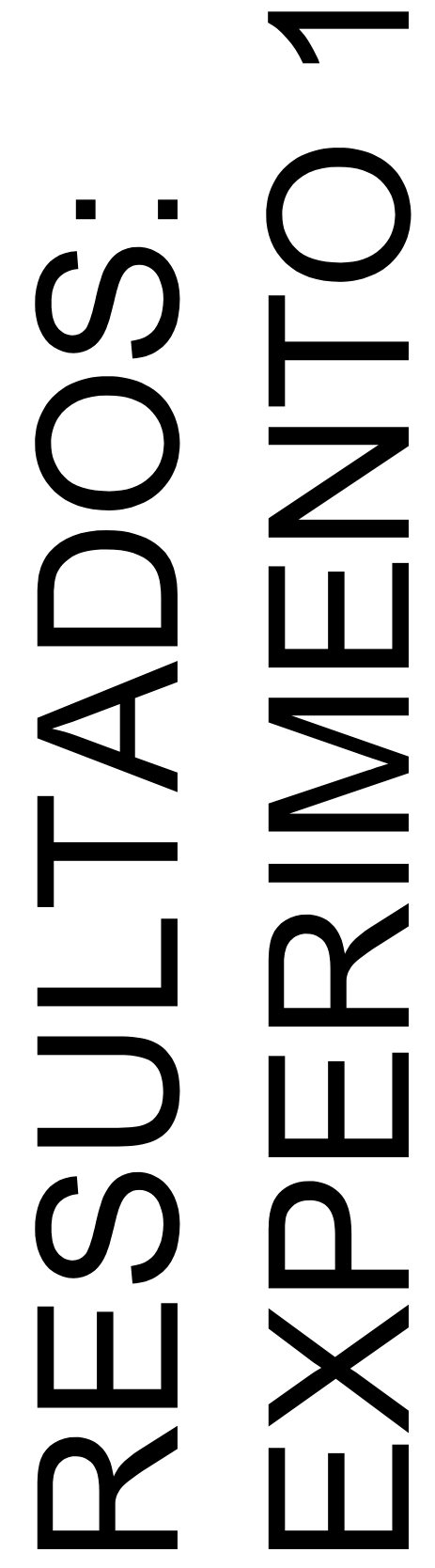




\section{RESULTADOS: EXPERIMENTO 1}

\section{A CAMKII REGULA A ROTAÇÃO DO FUSO MEIÓTICO APÓS A ATIVAÇÃO PARTENOGENÉTICA}

A distribuição e a organização dos filamentos de actina foram avaliadas por fluorescência, e estão apresentadas na figura 4. Os filamentos de actina encontravam-se distribuídos por todo o citoplasma nos oócitos em MII, com uma marcada concentração na membrana plasmática e especialmente na placa metafásica (Figura 4A-C). Após a ativação partenogenética foi observada uma diminuição na fluorescência dos filamentos de actina, quando comparada a dos oócitos em MII. A diminuição de intensidade de fluorescência pode representar uma despolimerização ou reorganização dos filamentos de actina. Esta redução da fluorescência dos filamentos de actina ocorreu tanto no citoplasma quanto na membrana plasmática.

Entretanto, a marcação fluorescente estava aumentada na região do fuso meiótico e no segundo corpúsculo polar, indicando aumento de filamentos de actina nestas estruturas (Figura 4D-F). Nos oócitos tratados com AIP, os filamentos de actina após a ativação partenogenética, se assemelhavam aos dos oócito em MII, distibuídos pelo citoplasma e com alta concentração na membrana plasmática. Porém, diferindo apenas pela forte organização ao redor do fuso meiótico (Figura 4G-I). 

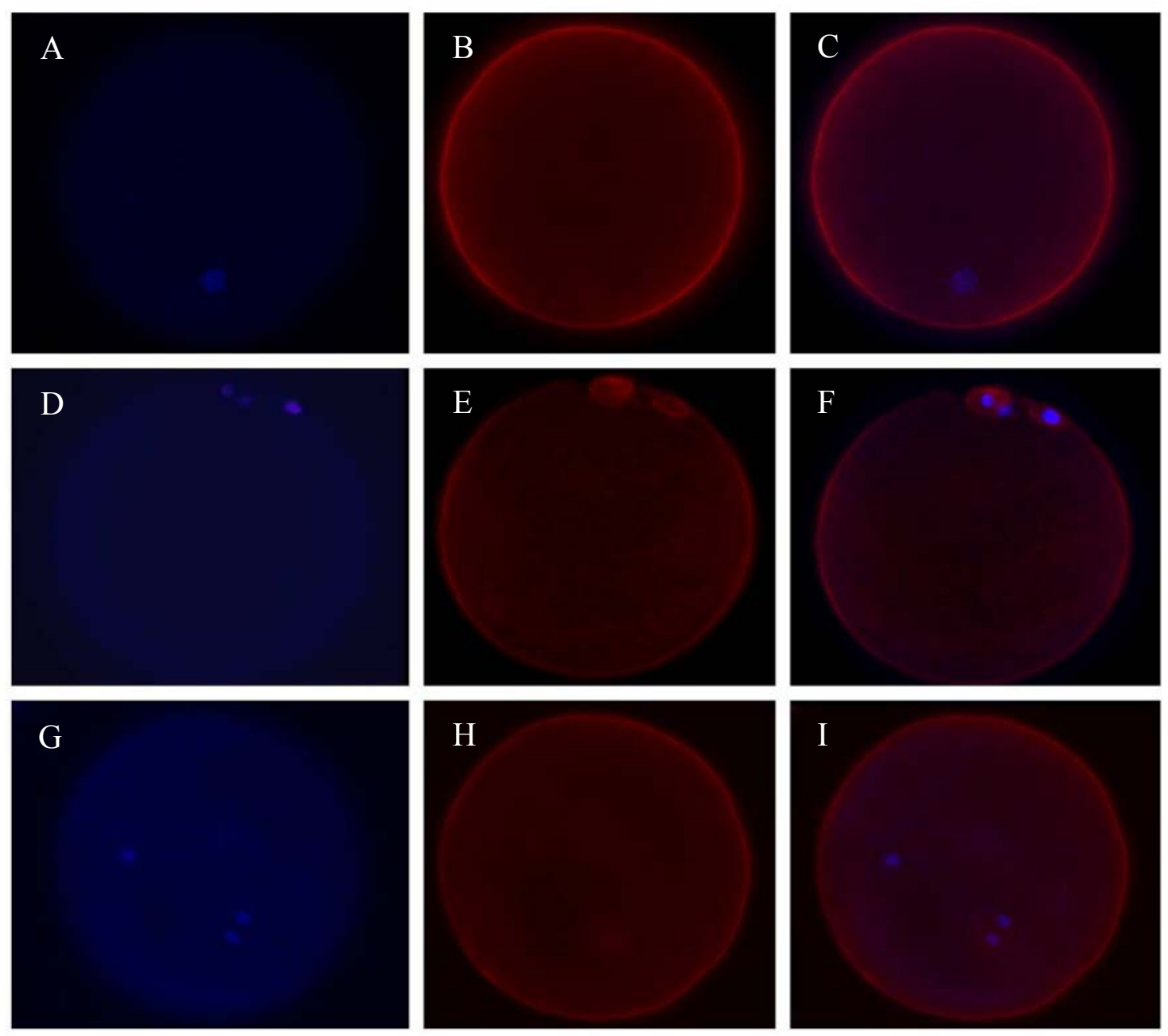

Figura 4 - Distribuição dos filamentos de actina em oócitos no estádio de MII e após a ativação partenogenética com ou sem o inibidor de CaMKII (AIP). Os filamentos de actina (vermelho) e a cromatina (azul) foram corados com faloidina e hoechst, respectivamente Os oócitos em MII apresentam os filamentos de actina distribuídos pelo citoplasma e com forte marcação na membrana plasmática (A-C). A ativação partenogenética induziu a despolimerização e/ou reorganização dos filamentos de actina (DF), que foi prevenida pela inibição da CaMKII (G-I)

A organização dos microtúbulos e a morfologia dos cromossomos estão apresentadas na figura 5. Nos oócitos em MII, os microtúbulos foram observados distribuídos por todo o citoplasma apresentando maior concentração no fuso meiótico (Figura. 5A-C). Após a ativação partenogenética, os oócitos retomaram a meiose progredindo pelo ciclo celular até a telófase II (92\%). As cromátides irmãs migraram para pólos opostos ao fuso ligeiramente alongado formado pelos microtúbulos. O fuso sofreu rotação, localizando-se verticalmente em relação à membrana plasmática (Figura 5D-F). A ativação dos oócitos tratados com $100 \mu \mathrm{M}$ de AIP não afetou a retomada da meiose ou a migração das cromátides irmãs para lados opostos ao fuso. O fuso apresentou morfologia ligeiramente alongada de forma semelhante Weber Beringui Feitosa 
aos oócitos ativados sem a presença do inibidor AIP. Entretanto, o tratamento com AIP inibiu a rotação do fuso meiótico (37\%), o qual, 1 hora após a ativação partenogenética continuavam se localizado paralelamente à membrana plasmática (Figura 5G-I)
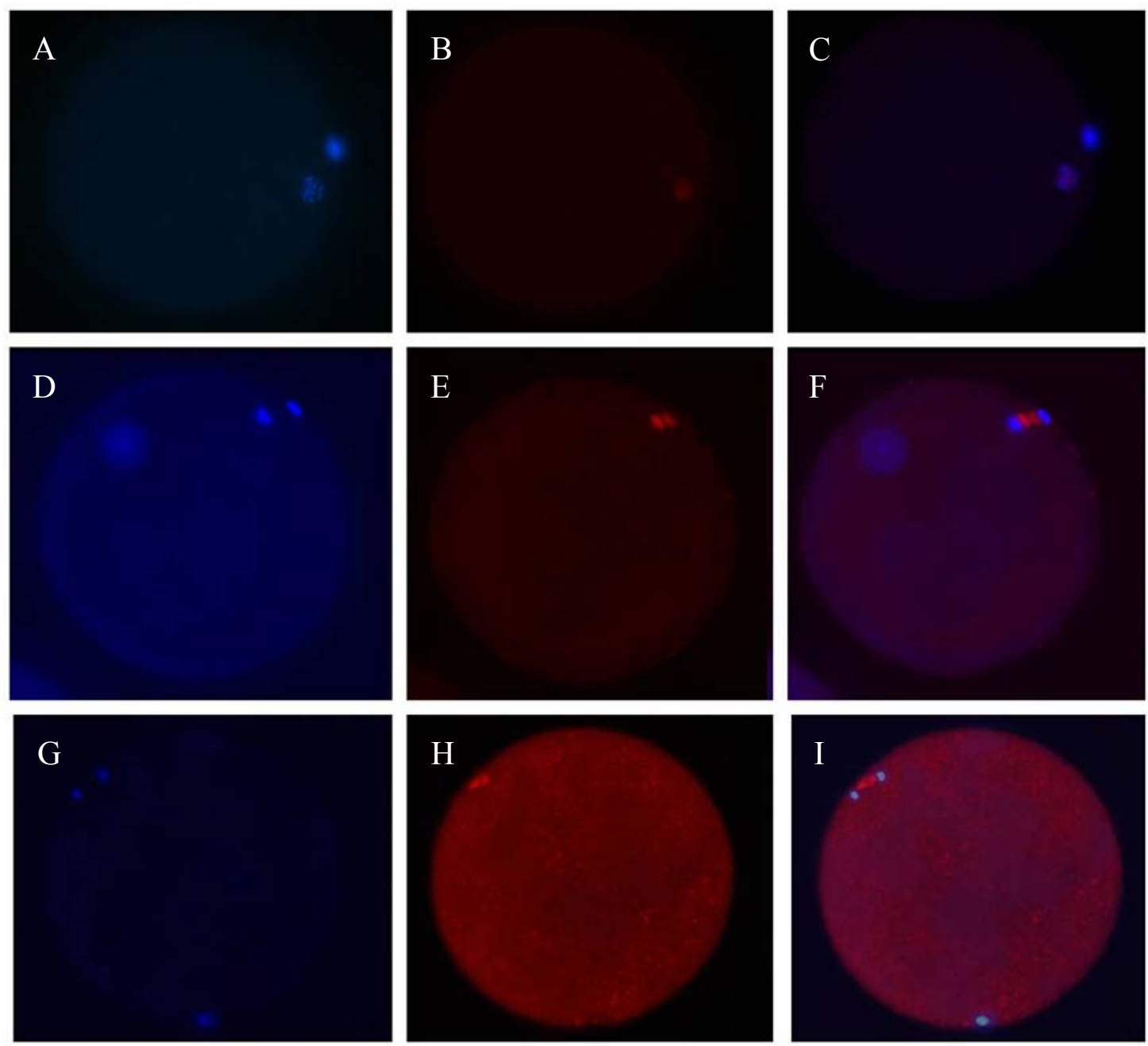

Figura 5 - Retomada da meiose após a ativação partenogenética com cálcio ionóforo e o efeito do inibidor de CaMKII (AIP) sobre a rotação do fuso meiótico. Os microtúbulos (vermelho) e a cromatina (azul) foram marcados com anticorpo anti- $\alpha$ tubulina e hoechst, respectivamente. Após 24 horas de maturação os oócitos alcançaram o estádio de MII e os microtúbuos estavam localizados em maior concentração no fuso meiótico (A-C). O cálcio ionóforo induziu a retomada da meiose e 1 hora após a ativação, o fuso não atingiu o estádio de telófase e apresentava orientação perpendicular à membrana plasmática e os cromossomos separados pelos microtúbulos em dois pólos (D-F). Nos oócitos nos quais a CaMKII foi inibida, o fuso não sofre rotação, após a ativação partenogenética (GI)

Como o inibidor de CaMKII afetou a organização dos filamentos de actina foi avaliado se esta alteração também poderia afetar a organização dos retículos endoplasmáticos (RE). Em oócitos no estádio de MII, o RE encontrava-se disperso pelo citoplasma, de maneira uniforme (Figura 6A).

Weber Beringui Feitosa 
Após a ativação partenogenética com cálcio ionóforo houve a migração dos RE para a região cortical (Figura 6B). Embora a fluorescência emitida pelo RE, disperso no citoplasma, tenha diminuído em relação aos oócito em MII, o mesmo continuou disperso pelo citoplasma com exceção da região ao redor do fuso (Figura 6C). A ativação partenogenética dos oóctitos tratados com AIP, não alterou a organização do RE em relação aos oócitos ativados partenogeneticamente, na ausência do AIP (Figura 6D).
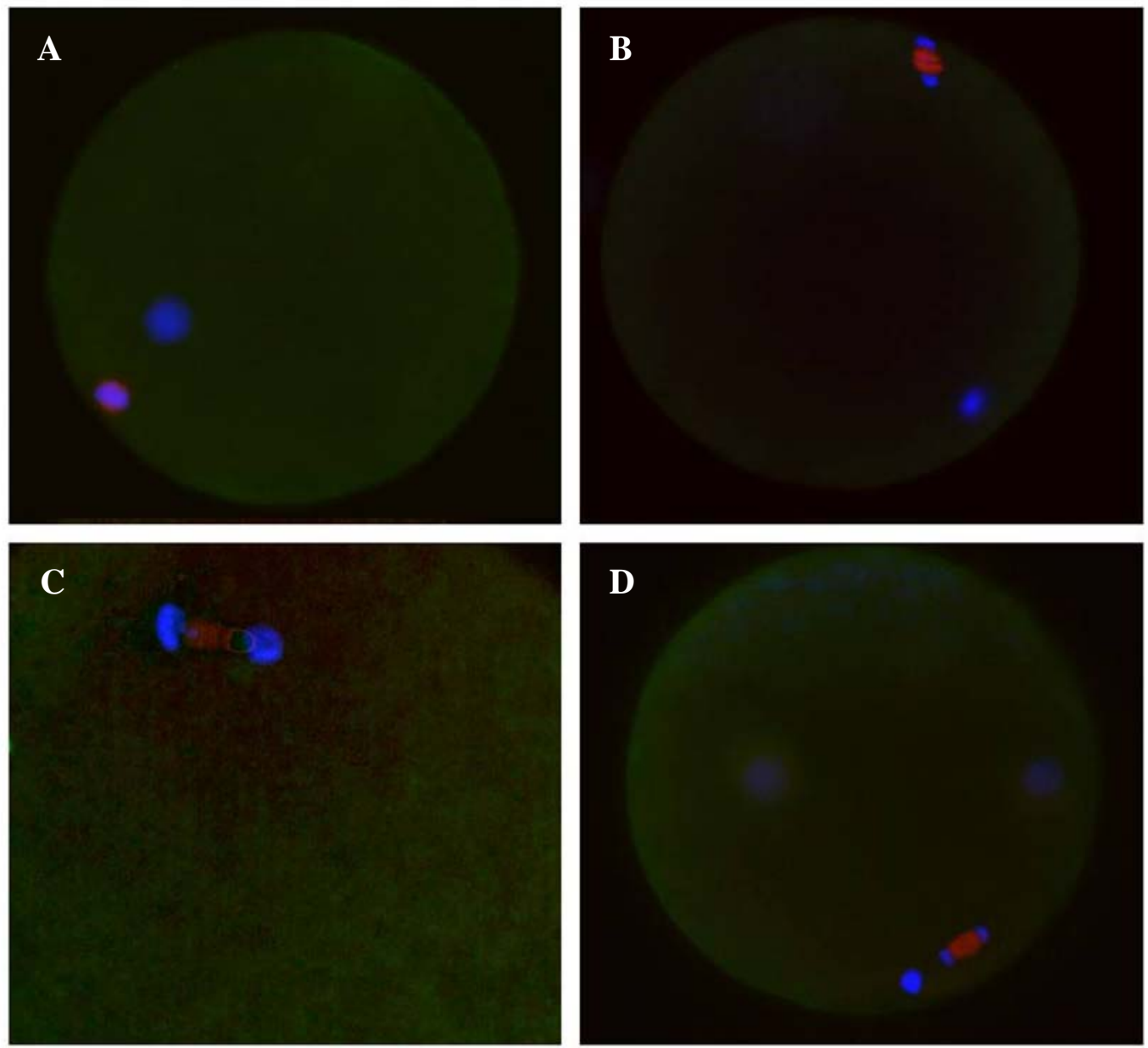

Figura 6 - Distribuição do RE em oócitos no estádio de MII e após a ativação partenogenética com ou sem o inibidor de CaMKII (AIP). O RE endoplasmático (verde), os microtúbulos (vermelho) e a cromatina (azul) foram corados com os anticorpos anti RE (PDI), anti-atubulina e com o hoechst, respectivamente. O RE se localiza de forma homogênea pelo citoplasma do oócito em MII (A). Após a ativação partenogenética ocorre a migração para a região cortical (B), embora uma menor quantidade permaneça distribuída pelo citoplasma, com exceção da região ao redor do fuso $(\mathrm{C})$. $\mathrm{O}$ uso o inibidor de CaMKII (AIP) não alterou o padrão de organização do RE, após a ativação partenogenética em relação aos oócitos ativados sem o uso do AIP (D) 


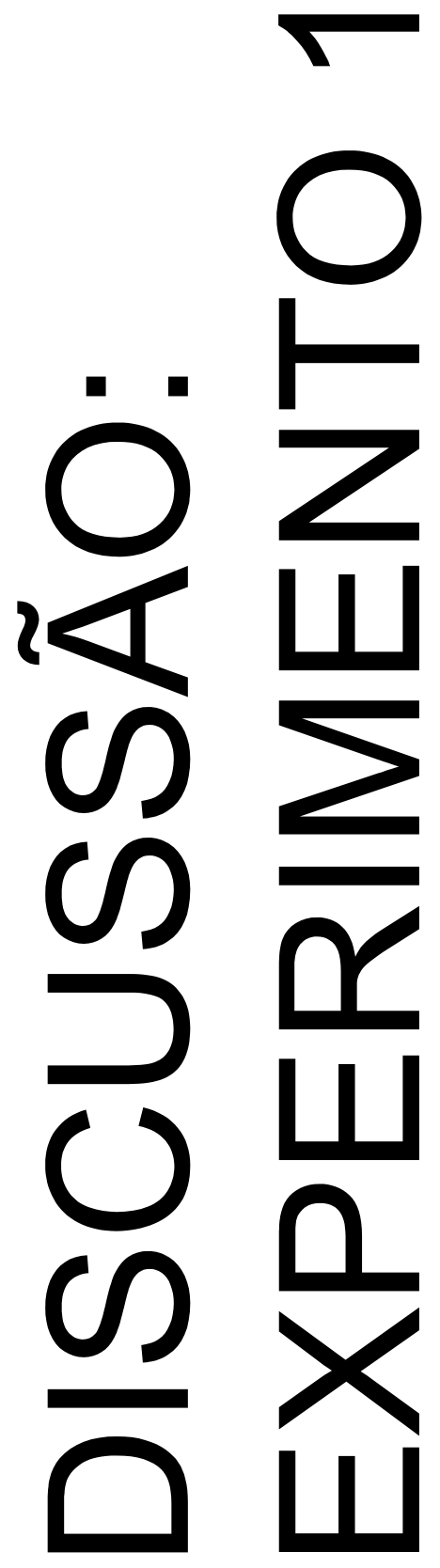




\section{DISCUSSÃO: EXPERIMENTO 1}

A proteína quinase dependente de calmodulina (CaMKII) está envolvida na regulação e na coordenação de vários processos celulares que ocorrem durante a ativação de oócitos de Xenopus (HANSEN et al., 2006), de camundongos (MADGWICK et al., 2005) e de suínos (FAN et al., 2003). Entretanto, não existem informações sobre a função da CaMKII na ativação de oócitos bovinos. Por este motivo, o papel da CaMKII na ativação de oócitos desta espécies foi estudada no presente trabalho.

Após a extrusão do corpúsculo polar, o oócito deve restabelecer o alto nível de atividade do MPF e deve permanecer bloqueado em MII até a fecundação. Na fecundação, a

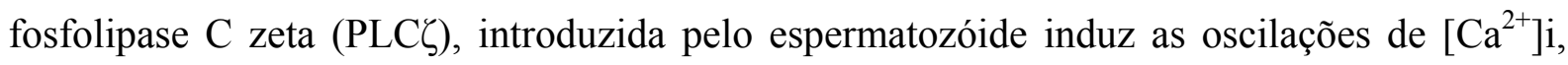
responsáveis pela ativação da CaMKII. Uma vez ativada, a CaMKII causa a degradação da Erp1/Emi2 ativando o complexo promotor de anáfase (APC), o que direciona pra a retomada da meiose.

A inibição da CaMKII bloqueia a progressão do ciclo celular em oócitos de rato (YOO; SMITH, 2007) e de suínos (FAN et al., 2003) ativados partenogeneticamente e também nos oócitos fecundados ou ativados partenogeneticamente de camundongos (JOHNSON et al., 1998; TATONE et al., 2002; MARKOULAKI; MATSON; DUCIBELLA, 2004). Resultado semelhante foi obtido com a microinjeção da sequência anti-sense do RNA para CaMKII, em oócitos de camundongos (CHANG et al., 2009) ou em camundongos knockout para CaMKII (BACKS et al., 2010). Por outro lado, a microinjeção de mRNA para a CaMKII constitutivamente ativa, induziu a retomada da meiose, mesmo na ausência de oscilações de $\left[\mathrm{Ca}^{2+}\right] \mathrm{i}$, reduzindo a atividade do MPF, da MAPK e a formação dos pró-núcleos (MADGWICK et al., 2005; CHANG et al., 2009).

Embora a CaMKII seja considerada a proteína alvo das oscilações de $\left[\mathrm{Ca}^{2+}\right] \mathrm{i}$, responsável pela retomada do ciclo celular, o tratamento com $100 \mu \mathrm{M}$ de AIP, utilizada no presente trabalho, não foi suficiente para manter os oócitos bloqueados em MII após a ativação partenogenética com cálcio ionóforo, já que $86 \%$ retomaram a meiose comparados aos $89 \%$ no grupo sem tratamento com AIP. Estes resultados sugerem que a CaMKII não participa da retomada da meiose na ativação dos oócitos em bovinos. 
Várias hipóteses podem explicar a diferença dos resultados do presente trabalho com os descritos na literatura em camundongos (TATONE et al., 2002; MARKOULAKI; MATSON; DUCIBELLA, 2004), suíno (FAN et al., 2003) e rato (YOO; SMITH, 2007). Uma delas poderia ser com relação a não eficiência do inibidor utilizado. Contudo, esta provavelmente não seja a explicação mais provável para o resultado aqui apresentado. O AIP tem ação no domínio auto-inibitório da CaMKII, no qual ocorre a substituição da alanina pela treonina. Isto confere ao AIP maior especificidade pela CamKII do que os outros inibidores comumente usados, como o KN-93 e KN-62, que marcam o domínio de ligação da CaM, podendo potencialmente inibir outras proteínas que também interagem por meio deste domínio (ISHIDA et al., 1995). Adicionalmente, o AIP tem sido usado com sucesso na inibição da atividade de CaMKII e por consequência, da retomada da meiose em oócitos de camundongos após a ativação (TATONE et al., 2002; MARKOULAKI; MATSON; DUCIBELLA, 2003, 2004)

Outra hipótese plausível pode ser o método de ativação utilizado. Neste trabalho, somente foi avaliado o envolvimento da CaMKII na ativação partenogenética em oócitos bovinos. No entanto, fisiologicamente esta ativação ocorre durante a fecundação. A atividade da CaMKII e o efeito dos respectivos inibidores são diferentes entre oócitos de camundongos fecundados ou ativados partenogeneticamente. Em oócitos de camundongos ativados partenogeneticamente com etanol foi observado um pico de atividade de CaMKII, 6,5 minutos após a ativação, caindo rapidamente depois. Contudo, em oócitos fecundados, a manutenção da atividade de CaMKII foi estimulada pelas oscilações de $\left[\mathrm{Ca}^{2+}\right]$ i (TATONE et al., 2002). Ao utilizarem o inibidor AIP, os autores relatam que a retomada da meiose foi bloqueada nos oócitos ativados partenogeneticamente, o que não ocorreu nos oócitos fecundados (TATONE et al., 2002).

Entretanto, Avaliar o papel da CaMKII em oócitos fecundados na espécie bovina é difícil e com resultados imprecisos. O tempo da penetração espermática, após a inseminação é assincrônico, variando de 6 a 10 horas pós-inseminação (MILAZZOTTO et al., 2008). Além disso, somente com a ativação partenogenética é possível se obter grande número de oócitos ativados simultaneamente e em um determinado tempo. Outro problema é a participação da CaMKII na motilidade espermática (MARÍN-BRIGGILER et al., 2005), o que dificulta a interpretação dos resultados. 
Se a CaMKII realmente participa da retomada da meiose em oócitos bovinos ativados partenogeneticamente, como participa em outras espécies, a hipótese mais provável da ausência de efeito na inibição da retomada nesta espécie poderia ser explicada pela concentração do inibidor utilizada neste experimento. Em oócitos de camundongo a concentração usada variou de $25 \mu \mathrm{M}$ (FAN et al., 2003) a $50 \mu \mathrm{M}$ (GARDNER et al., 2007). Neste experimento foi utilizado $100 \mu \mathrm{M}$ de AIP, concentração quatro vezes maior do que a dose mais baixa relatada para camundongos. Contudo, devido ao grande volume do oócito de bovinos, a concentração de AIP usada neste experimento pode não ter sido suficiente para inibir a retomada da meiose. Entretanto, Fan et al. (2003) relataram diminuição na formação de pró-núcleos em oócitos de suínos tratados com $20 \mu \mathrm{M}$ de AIP (86,67\% no grupo controle para 10,99\% no grupo tratado com $20 \mu \mathrm{M}$ de AIP). Como o oócito de suíno possui volume celular próximo ao de bovino, a inibição da retomada da meiose em suíno com uma dose de AIP 5 vezes menos concentrado ao do presente trabalho, praticamente exclui a hipótese de uma concentração inadequada de inibidor, para explicar a ausência do efeito na retomada da meiose em bovinos.

Excluindo a possível inespecificidade ou dose inadequada do inibidor, outra explicação da ausência de inibição do AIP é a não participação da CaMKII na retomada da meiose na espécie bovina. A ativação de oócitos bovinos tem se mostrado diferente das demais espécies. A injeção intracitoplasmática de espermatozóide (ICSI) em bovinos, falha em estabelecer índices normais de desenvolvimento embrionário e fetal, na ausência de algum estímulo exógeno de ativação como $\mathrm{Ca}^{2+}$ ou inibidores de ciclinas da fase-M (RHO et al., 1998, CHUNG et al., 2000; SUTTNER et al., 2000). Recentemente tem sido demonstrado, que o espermatozóide bovino submetido à ICSI não sofre dissolução da teca perinuclear (uma densa matriz de citoesqueleto adjacente ao núcleo) como ocorre durante a fecundação propriamente dita (SUTOVSKY et al., 2003). Adicionalmente, após a ICSI o espermatozóide bovino não tem a capacidade de iniciar as oscilações de $\left[\mathrm{Ca}^{2+}\right] \mathrm{i}$ em oócito bovino, mas consegue iniciá-las quando submetido à ICSI em oócitos de camundongo. Por outro lado, o espermatozóide de camundongo não tem a capacidade de iniciar as oscilações de $\left[\mathrm{Ca}^{2+}\right] \mathrm{i}$ em oócitos bovinos após a ICSI (KNOTT et al., 2003; MALCUIT et al., 2006). Estes experimentos indicam que a incapacidade da indução das oscilações de $\left[\mathrm{Ca}^{2+}\right] \mathrm{i}$ na espécie bovina talvez seja devido a uma combinação de fatores espermáticos e oócitários e que em bovinos o processo de ativação do oócito talvez seja diferente das demais espécies. 
As oscilações de $\left[\mathrm{Ca}^{2+}\right]$ i durante a fecundação são estimuladas pela liberação da PLC $\zeta$ do espermatozóide dentro do citoplasma do oócito. Em camundongos tem sido demonstrado que a PLC $\zeta$ migra do citoplasma para o pró-núcleo ao término das oscilações de $\left[\mathrm{Ca}^{2+}\right] \mathrm{i}$ (ITO

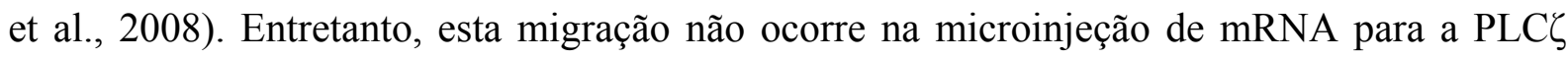
bovina em oócitos de bovinos e de camundongos. Entretanto, quando se microinjeta mRNA da PLCל murina em oócitos de bovinos, esta também migra para o pró-núcleo, como ocorre em oócitos de camundongos (No prelo) ${ }^{2}$. Como o oócito bovino apresenta grande particularidade em relação ao mecanismo de ativação e liberação de $\left[\mathrm{Ca}^{2+}\right] \mathrm{i}$ em comparação com as outras espécies, é plausível supor que as proteínas que respondem às oscilações de $\left[\mathrm{Ca}^{2+}\right] \mathrm{i}$ regulando os eventos da ativação, como a retomada da meiose também possam ser diferentes.

Deste modo, a hipótese mais provável para o resultado do presente trabalho é que a CaMKII não participa na retomada da meiose em oócitos bovino, no qual este é o primeiro trabalho a demonstrar isso.

De qualquer maneira, independente da explicação da ausência de efeito do AIP na retomada da meiose, o presente trabalho mostra pela primeira vez que a CaMKII regula a rotação do fuso meiótico no estádio de telófase II. Este fenômeno nunca foi observado em outras espécies na qual a CaMKII foi estudada devido ao fato desta proteína participar da retomada da meiose nestas espécies. Deste modo, a inibição da CaMKII nestes trabalhos, induz o bloqueio dos oócitos em MII após a ativação, impedindo a observação de qualquer efeito da CaMKII em eventos posteriores.

Em suínos, um nível básico da atividade de CaMKII é observada nos oócitos em MII. Esta atividade aumenta drasticamente atingindo atividade máxima 15 minutos após a ativação partenogenética por estimulação elétrica. Após este pico, a atividade de CaMKII diminui progressivamente voltando a aumentar e a atingir um novo pico no momento em que os oócitos entram em telófase II. Estes resultados demonstram que a CaMKII possui grande atividade em dois momentos da progressão do ciclo celular durante a ativação (FAN et al., 2003). Assim, embora neste experimento a inibição da CaMKII não tenha tido efeito na retomada da meiose, momento em que ocorre o primeiro pico de atividade desta quinase, a

\footnotetext{
${ }^{2}$ COONEY, M. A.; MALCUIT, C.; CHEON, B.; HOLLAND, M.K.; FISSORE, R.A.; D'CRUZ, N. T. Speciesspecific differences in activity and nuclear localization of murine and bovine phospholipase C, zeta 1. Biology of Reproduction. DOI:10.1095/biolreprod.109.079814
} 
inibição desta apresentou efeito na rotação do fuso meiótico ao iniciar a telófase, momento em que é descrito um segundo pico de atividade da CaMKII (FAN et al., 2003).

Em oócitos após a ativação, o fuso meiótico deve sofrer rotação do eixo antes da telófase, estágio no qual o $2^{\circ}$ corpúsculo polar será originado (LIU et al., 2000). O eixo de rotação muda de paralelo para perpendicular à membrana plasmática. Experimentos que utilizam a citocalasina D (despolimerizador de filamentos de actina) demonstram que os microfilamentos de actina estão envolvidos neste processo (ZHU et al., 2003; NAVARRO et al. 2005). Adicionalmente, a inibição da miosina (proteína reguladora de filamentos de actina) inibiu a rotação do fuso prevenindo a extrusão do $2^{\circ}$ corpúsculo polar (MATSON et al., 2006).

No presente trabalho, após a ativação partenogenética foi observado uma diminuição da fluorescência para os microfilamentos de actina na membrana plasmática. Entretanto, esta diminuição não foi observada quando a CaMKII foi inibida pelo AIP, demonstrando a regulação da organização de microfilamentos de actina pela CaMKII.

Como tem sido descrito, a organização do retículo endoplasmático (RE) é regulada pelos microfilamentos e não pelos microtúbulos (FITZHARRIS et al., 2007), o presente trabalho avaliou se a CaMKII, pelo fato de regular os microfilamentos na rotação do fuso meiótico, também regularia a organização do $\mathrm{RE}$, via microfilamento, na ativação partenogenética de oócitos bovinos.

Foi observado que o RE se distribui de forma homogênea pelo citoplasma do oócito em MII. Após a ativação partenogenética ocorreu a migração destes para a região cortical, sendo que uma pequena quantidade permaneceu distribuída pelo citoplasma. Padrão similar de distribuição foi descrito por Payne e Schatten (2003) em oócitos de bovinos, após a fecundação.

Ao ser inibida, a CaMKII não alterou a distribuição do RE após a ativação partenogenética. Embora o presente trabalho tenha demonstrado que a CaMKII regula a organização dos microfilamentos, o fato da inibição desta não alterar a organização do RE após a ativação partenogenética, demonstra que em oócitos bovinos a organização do RE não é regulada pelos microfilamentos ou que esta organização possivelmente seja regulada por outra proteína quinase. 


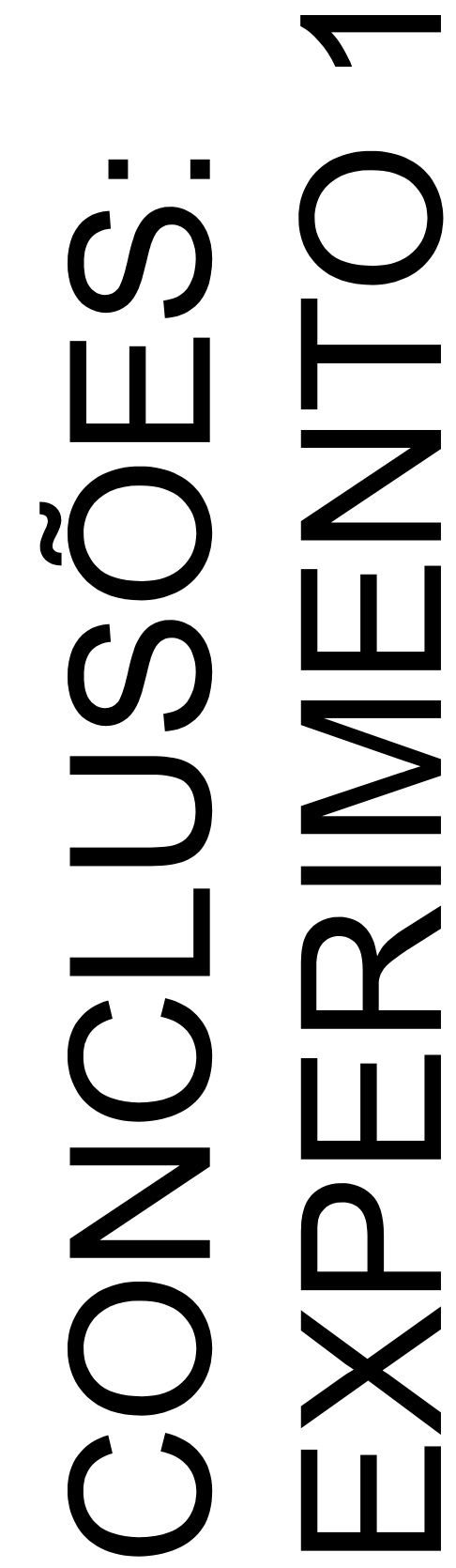




\section{CONCLUSÕES: EXPERIMENTO 1}

Baseado nos resultados, as conclusões deste trabalho foram:

1 - A CaMKII não participa da retomada da meiose em oócitos bovinos ativados partenogeneticamente.

2 - A organização dos microtúbulos não é regulada pela CaMKII.

3 - A CaMKII regula a organização dos filamentos de actina.

4 - A CaMKII coordena a rotação do fuso meiótico em telófase II.

4 - A distribuição do retículo endoplasmático não é coordenada pela CaMKII.

Baseado nas conclusões foi formulado o modelo hipotético gráfico apresentado na figura 7.

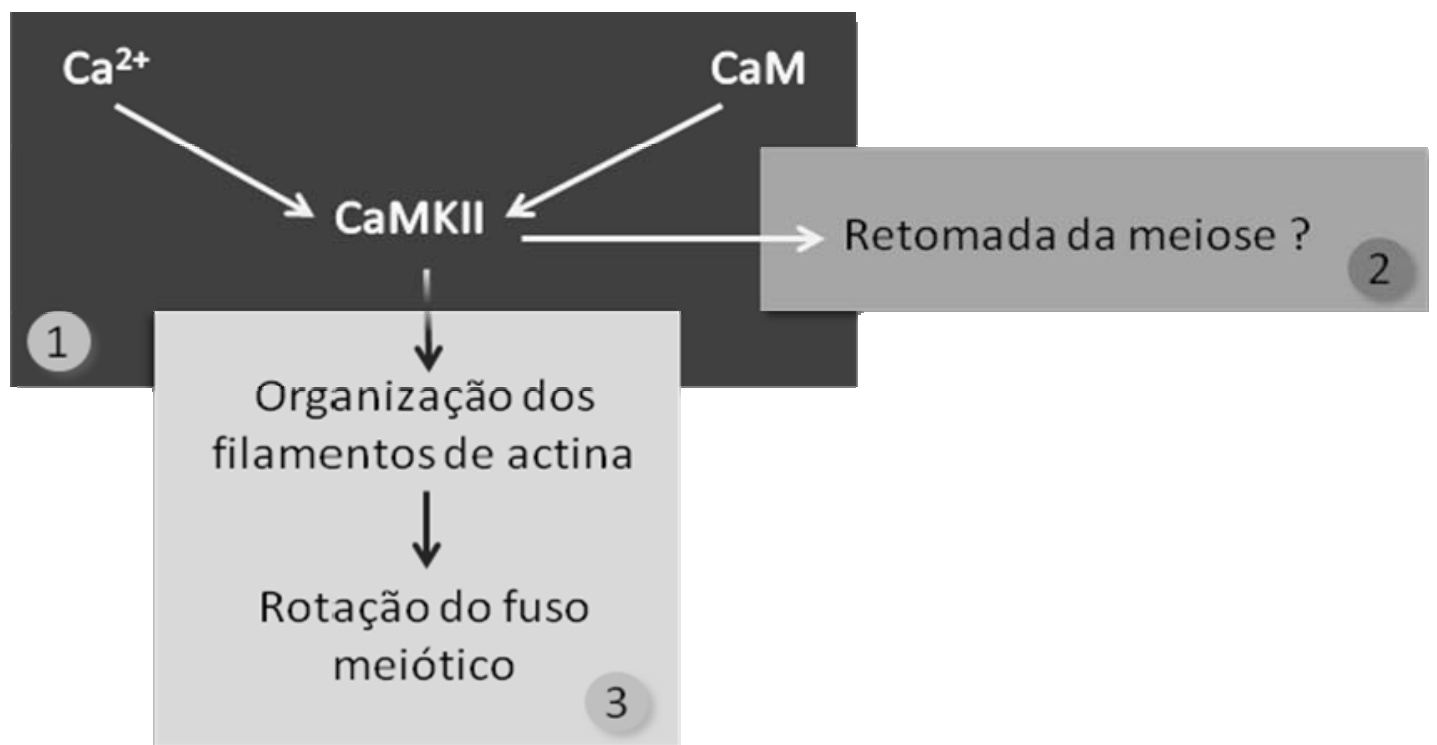

Figura 7 - Modelo hipotético gráfico da participação da CaMKII na ativação partenogenética de oócitos bovinos. $1-\mathrm{O} \mathrm{Ca}^{2+}$ se liga a CaM que ativa a CaMKII. 2 - A CamKII ativada regula a organização dos filamentos de actina que por sua vez são responsáveis pela rotação do fuso meiótico nos oócitos em telófase II. 3 - A CaMKII não participa da retomada da meiose após a ativação partenogenética de oócitos bovinos. Para confirmar esta hipótese, novos experimentos necessitam ser realizados 

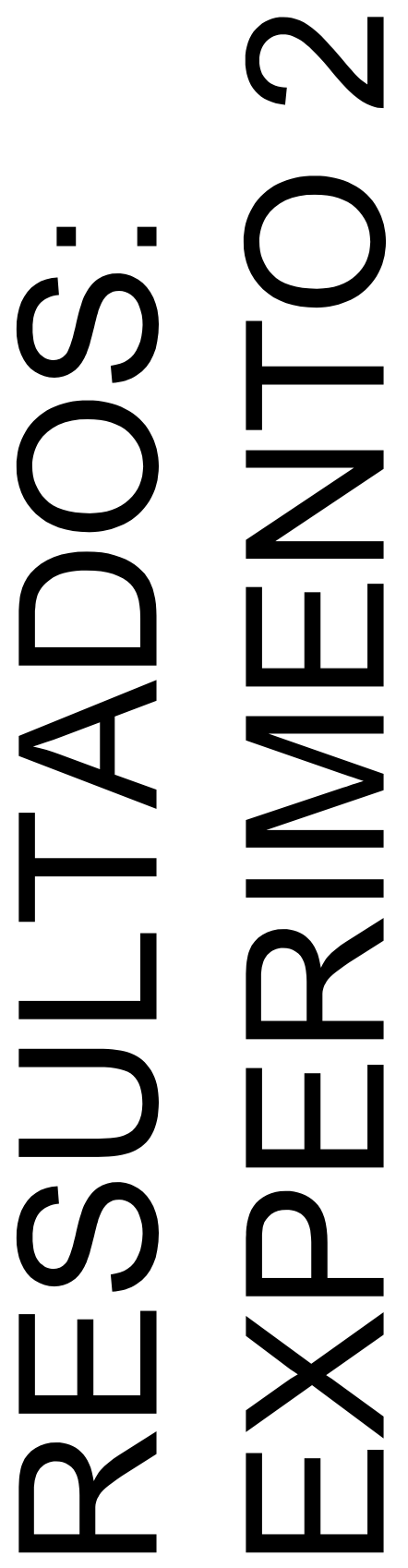


\section{RESULTADOS: EXPERIMENTO 2}

\section{A REORGANIZAÇÃO DO RETÍCULO ENDOPLASMÁTICO APÓS A ATIVAÇÃO É REGULADA PELA PKC}

A organização dos microtúbulos e a morfologia dos cromossomos foram avaliadas por imunofluorescência e os resultados estão apresentados na figura 8. Os microtúbulos foram observados distribuídos por todo o citoplasma apresentando maior concentração no fuso meiótico dos oócitos em MII (Figura 8A-C). A ativação partenogenética induzida pelo cálcio ionóforo ocasionou a retomada e a progressão da meiose até o estádio de telófase II. As cromátides irmãs migraram para pólos opostos do fuso ligeiramente alongado formado pelos microtúbulos, sofrendo rotação e localizando-se verticalmente em relação à membrana plasmática (Figura 8D-F). Nos oócitos ativados partenogeneticamente na presença de $10 \mu \mathrm{M}$ do inibidor de PKC "Bisindolylmaleimide I" (BIM), a retomada da meiose e a migração das cromátides irmãs para lados opostos do fuso não foi afetada. O fuso apresentou morfologia ligeiramente alongada e sofreu rotação de forma semelhante aos dos oócitos ativados sem a presença do inibidor (Figura 8G-I). 

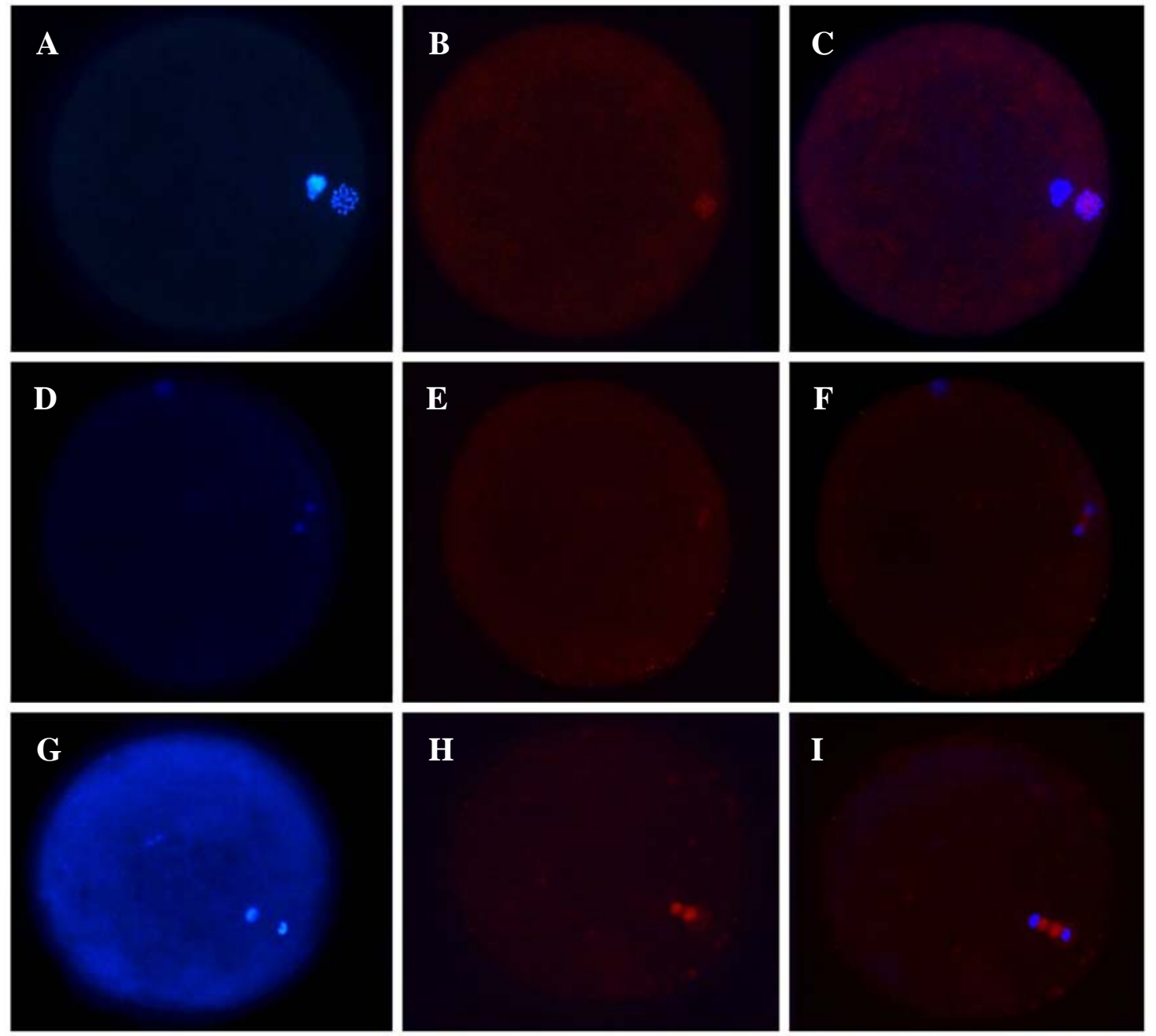

Figura 8 - Organização e distribuição dos microtúbulos nos oócitos em MII e após a ativação partenogenética induzida pelo cálcio ionóforo, tratados ou não com o inibidor de PKC (BIM). Os microtúbulos (vermelho) e a cromatina (azul) foram corados com anticorpo anti-atubulina e hoechst, respectivamente. Nos oócitos em MII, os microtúbulos estavam localizados em maior concentração no fuso meiótico (A-C). A retomada da meiose foi induzida pelo cálcio ionóforo e 1 hora após a ativação o oócito não atingiu o estádio de telófase II, apresentando orientação perpendicular à membrana plasmática e os cromossomos separados pelos microtúbulos em dois pólos (D-F). O mesmo padrão foi observado nos oócitos ativados na presença de BIM (G-I). Aumento de 250X

A distribuição e organização intracelular dos filamentos de actina nos oócitos em MII e nos ativados partenogeneticamente foi avaliada utilizando a toxina faloidina marcada com Alexa Fluor 568, que em baixas concentrações pode ser utilizada como um marcador fluorescente para microfilamentos de actina. Nos oócitos em MII, os filamentos de actina encontravam-se distribuídos por todo o citoplasma com acentuada concentração na membrana plasmática e no fuso meiótico (Figura 9A-C). 
Após a ativação partenogenética, ainda estava presente uma forte marcação dos filamentos de actina no fuso meiótico. Entretanto, uma diminuição na fluorescência destes filamentos foi observada, na membrana plasmática (Figuira 9C-D), quando comparado com oócitos em MII. Já na presença do inibidor da PKC, após a ativação partenogenética, os filamentos de actina encontravam-se distribuídos pelo citoplasma havendo pouca concentração destes na membrana plasmática. Entretanto, a forte organização ao redor do fuso meiótico continuou presente (Figura 9G-I).
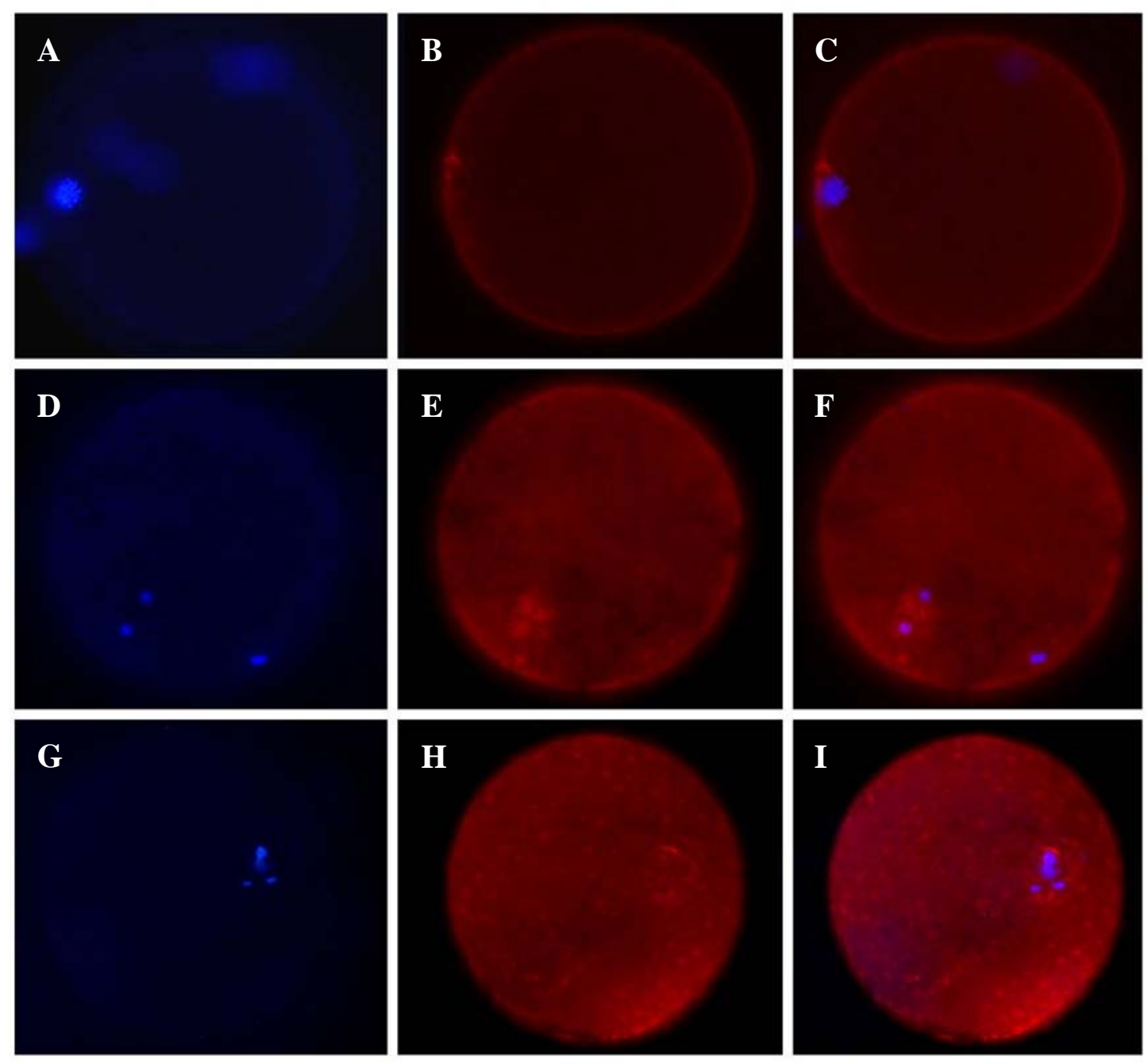

Figura 9 - Distribuição dos filamentos de actina em oócito no estádio de metáfase II e após a ativação partenogenética na presença ou ausência do inibidor de PKC (BIM). Os filamentos de actina (vermelho) e a cromatina (azul) foram corados com faloidina e hoechst, respectivamente. Nos oócitos em MII os filamentos estavam distribuídos pelo citoplasma e com forte marcação na membrana plasmática (A-C). A ativação partenogenética diminuiu fluorescência dos filamentos de actina na membrana plasmática (D-F), sendo esta diminuição mais acentuada nos oócitos ativados na presença de BIM (G-I) 
A distribuição do retículo endoplasmático (RE) foi avaliada por imunofluorescência no oócito em MII e após a ativação partenogenética, na presença ou ausência de BIM (Figura 10), com intuito de investigar o papel da PKC na reorganização deste. Nos oócitos em MII, o RE encontrava-se aglomerado (cluster) no córtex, contíguo à membrana plasmática (Figura 10A-C). Após a ativação partenogenética, o RE mudou o padrão de distribuição, passando a se localizar por todo o citoplasma (Figura 10D-F). A reorganização e a dispersão dos aglomerados de RE após a ativação foram inibidas pelo BIM. A inibição da PKC induziu uma aproximação dos aglomerados de RE, de forma densa, na região cortical do oócito (Figura 10G-I).
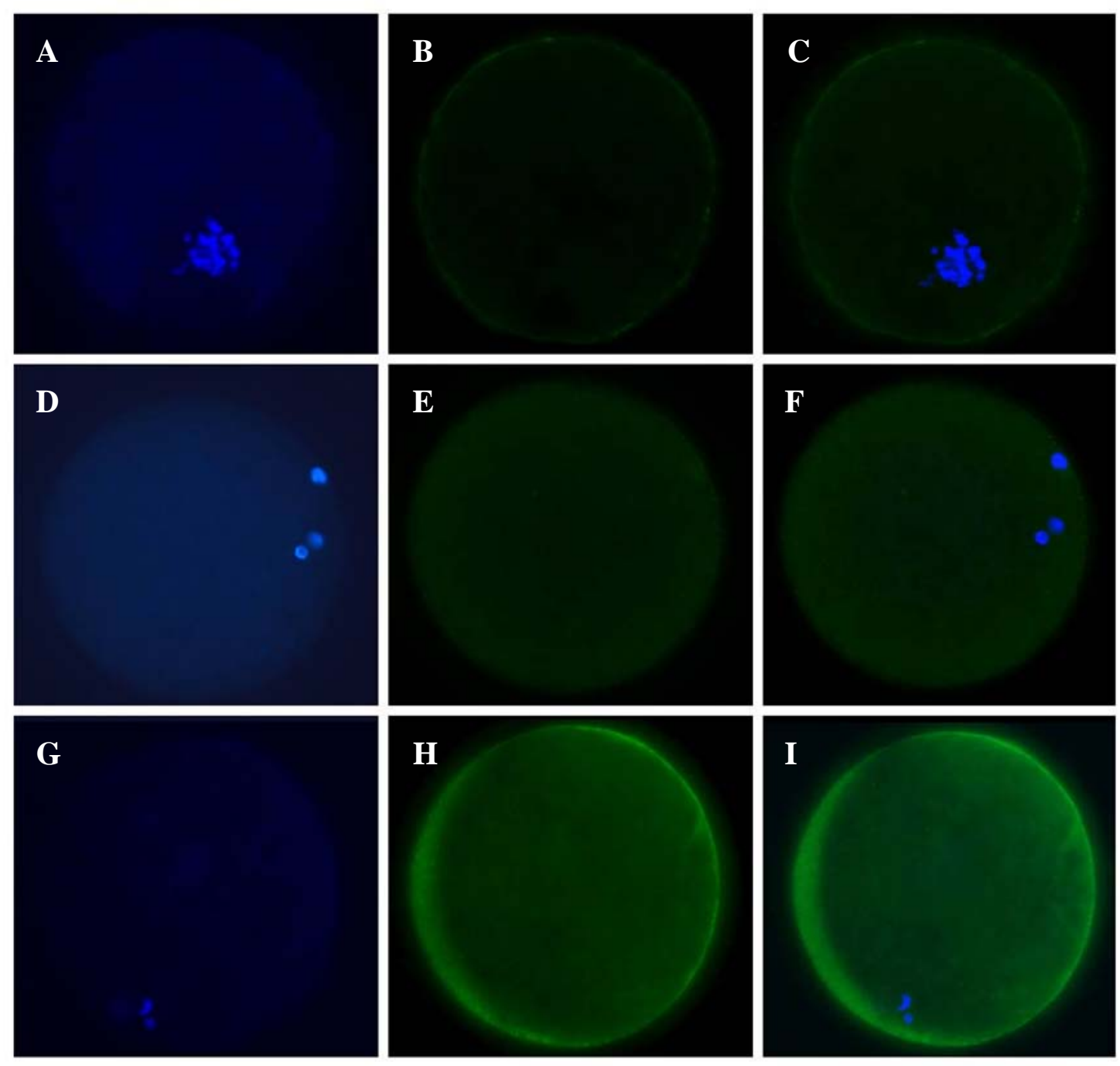

Figura 10 - Distribuição do RE em oócitos no estádio de MII e após a ativação partenogenética com ou sem o inibidor de PKC (BIM). O RE endoplasmático (verde) e a cromatina (azul) foram corados com anticorpo anti RE (PDI) e hoechst, respectivamente. O RE se encontra aglomerado (cluster) no córtex junto à membrana plasmática do oócito em MII (A-C). Após a ativação partenogenética, o RE continua aglomerado, porém se difundindo por todo o citoplasma (D-F). A inibição da PKC afetou a reorganização do RE, podendo ser observado de forma densa na região cortical (G-I) 
Para avaliar o papel dos filamentos de actina na reorganização do RE, os oócitos foram ativados na presença da droga despolimerizadora de actina, a citocalasina. Nos oócitos em MII, os filamentos de actina se encontravam localizados junto ao RE (coloração alaranjada), na região cortical do oócito (Figura 11A). Após a ativação partenogenética, o RE se distribuiu pelo citoplasma (Figura 11B), contudo ao utilizar o inibidor da PKC, o padrão de distribuição do RE foi diferente, estando localizado em grande concentração na região cortical (Figura 11C). Resultado semelhante ao da inibição da PKC foi obtido quando os filamentos de actina foram despolimerizado pela citocalasina (Figura 11D).
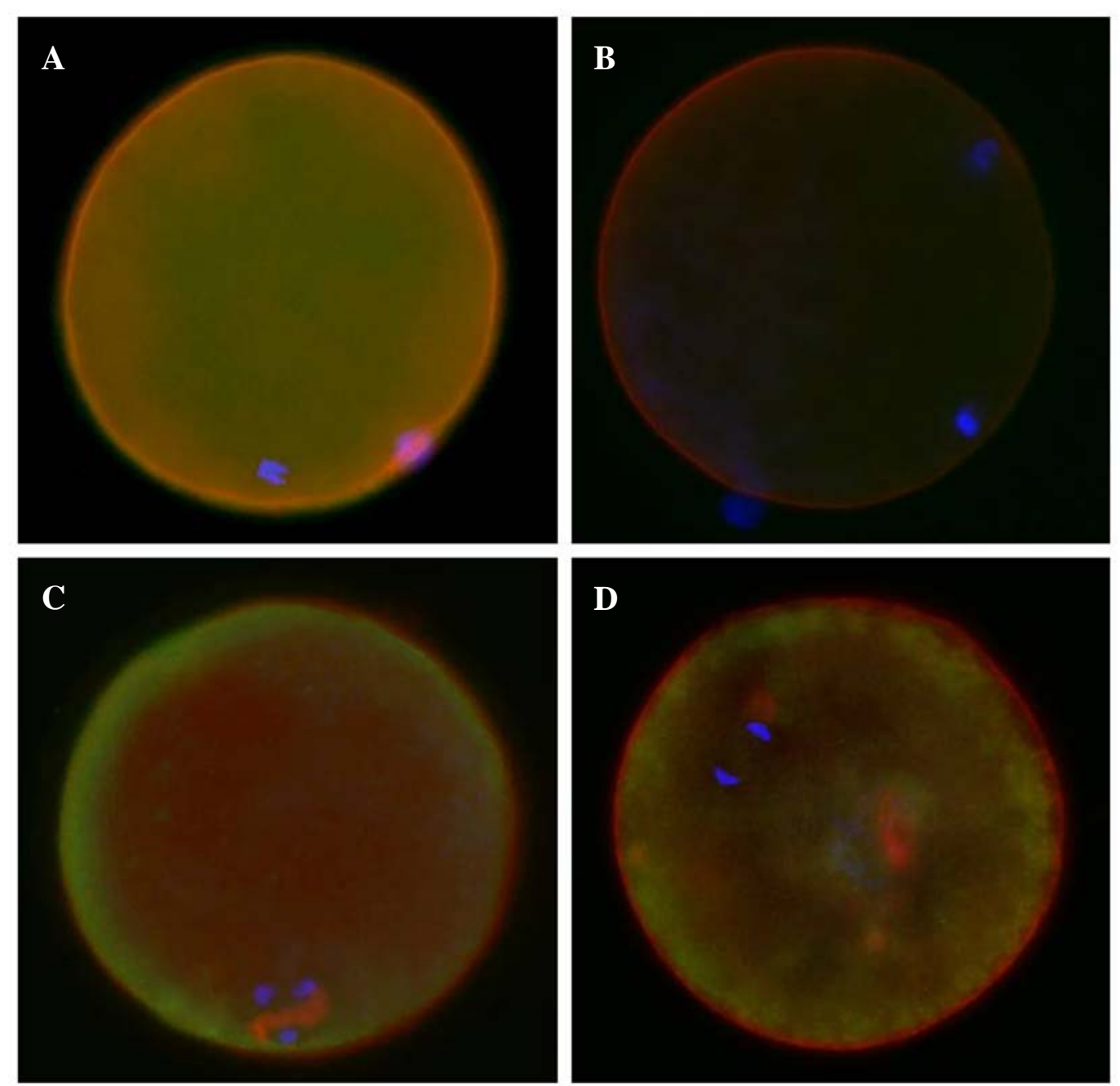

\footnotetext{
Figura 11 - Efeito da despolimerização dos filamentos de actina na organização do RE. Distribuição do RE em oócitos no estádio de MII (A) e após a ativação partenogenética na ausência do inibidor BIM (B), presença (C) ou com o despolimerizador de filamentos de actina, citocalasina (D). O RE endoplasmático (verde) e os filamentos de actina (vermelho) foram corados com anticorpo anti RE (PDI) e faloidina
} 


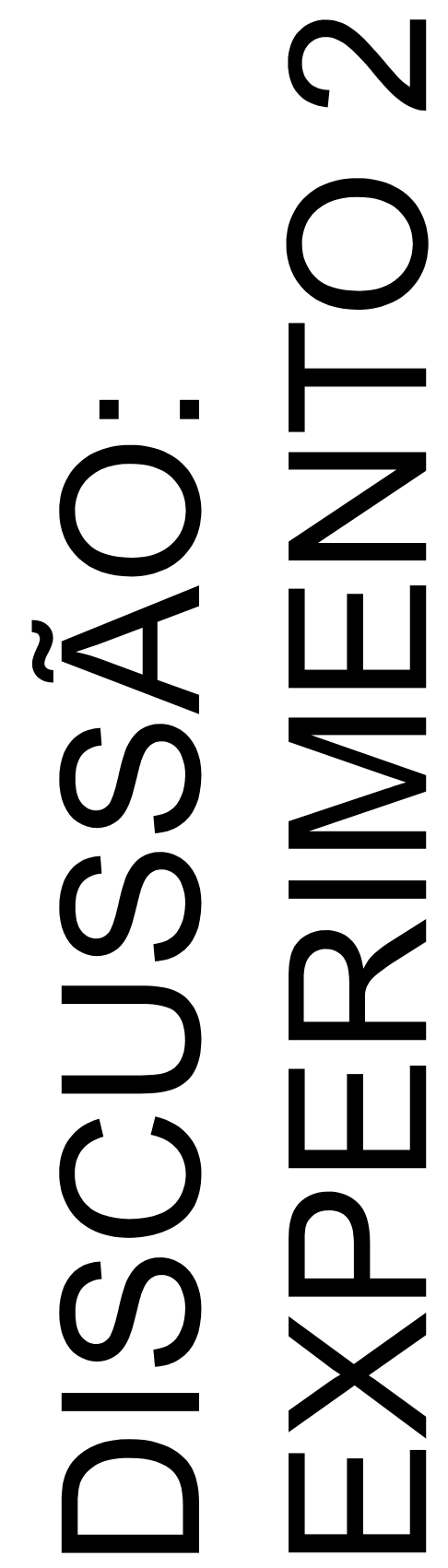




\section{DISCUSSÃO: EXPERIMENTO 2}

A PKC é uma proteína quinase que participa ativamente da ativação do oócito (DUCIBELLA et al., 1993; ELIYAHU et al., 2002), sendo as isoformas convencionais ativadas por $\mathrm{Ca}^{2+}$ e DAG durante a fecundação (RAZ et al., 1998; LURIA et al., 2000). Entretanto, pouco se sabe sobre a função da PKC na ativação de oócitos nos bovinos. Objetivando preencher esta lacuna, o presente trabalho estudou a importância da PKC no processo de ativação de oócitos nesta espécie.

A atividade da PKC aumenta durante a ativação do oócito, podendo esta atividade ser avaliada diretamente (GALLICANO et al., 1997), ou indiretamente pela redistribuição de várias isoformas para a membrana plasmática (LURIA et al., 2000; ELIYAHU; SHALGI, 2002). Adicionalmente, tem sido relatado que a inibição farmacológica da PKC previne a saída do bloqueio meiótico em MII (GALLICANO et al., 1997), e que a ativação induz a retomada da meiose (GALLICANO et al., 1993; COLONNA et al., 1997; LURIA et al., 2000).

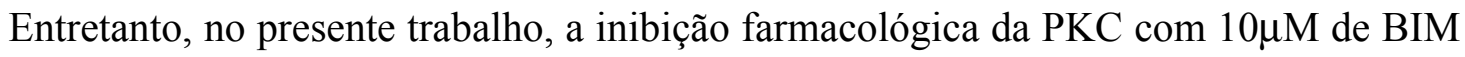
não foi suficiente para prevenir a retomada da meiose após a ativação partenogenética com $5 \mu \mathrm{M}$ de cálcio ionóforo. Tanto os oócitos tratados com o inibidor de PKC quanto os sem inibidor, retomaram a meiose progredindo pelo ciclo celular até o estádio de telófase, 1 hora após a ativação partenogenética. Em experimento prévio dose-resposta foi observado que concentrações de BIM acima de $10 \mu \mathrm{M}$ induzem alterações morfológicas e acima de $50 \mu \mathrm{M}$, a degradação dos oócitos ativados partenogeneticamente (dados não apresentados). Isto demonstra que em oócitos de bovinos, a retomada da meiose, após a ativação partenogenética, não é regulada pela PKC. De fato, os resultados aqui apresentados vão de acordo com trabalhos prévios que demonstram que a retomada da meiose é independente de PKC (GALLICANO et al., 1993; RAZ et al., 1998). O mesmo foi relatado por Madgwick et al., (2005) que observaram que a microinjeção de mRNA da forma ativa da PKC em oócitos de camundongo não induziu a retomada da meiose.

A controvérsia do papel da PKC descrito na literatura (GALLICANO et al., 1993; COLONNA et al., 1997; RAZ et al., 1998; LURIA et al., 2000; MADGWICK et al., 2005) pode ser devido ao uso de inibidores e ativadores farmacológicos que podem afetar processos que não teriam função fisiológica durante a fecundação ou afetar a atividade de outras 
proteínas. Por exemplo, altas concentrações do ativador de PKC "PAM" podem ocasionar oscilações de $\mathrm{Ca}^{2+}$ em oócitos de camundongos induzindo a retomada da meiose. Por outro lado, uma alta concentração do inibidor BIM pode inibir a proteína quinase A (PKA), que regula o ciclo celular, pelo controle da degradação de cilcina (GRIECO et al., 1996)

Atualmente a microinjeção de mRNA da forma ativa de uma proteína específica tem sido considerado a estratégia mais eficiente para se avaliar a função desta proteína em um determinado evento. A proteína ativa mimetiza o que ocorre fisiologicamente e os resultados dos trabalhos que utilizam esta tecnologia são considerados mais fidedignos do que os que utilizam inibidores ou ativadores farmacológicos. Todavia, a microinjeção de mRNA originará uma proteína ativa que desempenhará uma função, sendo que está não ocorreria naquele determinado momento dentro da célula. Os eventos que porventura ocorrerem em cascata ao ser desencadeados pelo mRNA podem ativar todas as proteínas de forma simultânea ou desordenadamente.

Embora tenha sido demonstrado que a atividade da PKC aumenta na ativação do oócito (GALLICANO; MCGAUGHEY; CAPCO, 1997; LURIA et al., 2000; ELIYAHU; SHALGI, 2002; HALET et al., 2004), provavelmente também possua funções em outros eventos mecanismos da ativação oocitária, independentes do ciclo celular. Uma destas funções foi recentemente demonstrada (HALET et al., 2004; MADGWICK et al., 2005). Estes autores relatam um importante papel desta proteína na "entrada de $\mathrm{Ca}^{2+}$ operada por estoque" (SOCE) durante a fecundação, estando envolvida na recarga dos estoques deste íon controlando o influxo durante cada onda. Estes achados ajudam a explicar a diferença nos resultados sobre o papel da PKC na retomada da meiose. É provável que para alguns inibidores ou ativadores o bloqueio ou indução da retomada de meiose, respectivamente, não seja porque a PKC transduza o sinal do $\mathrm{Ca}^{2+}$ para a retomada da meiose, mas sim porque está envolvida na regulação das oscilações de $\mathrm{Ca}^{2+}$ necessárias para a ativação de outras proteínas, sendo que estas efetivamente participam da retomada da meiose.

Nos oócitos no estádio de $\operatorname{MII}$, a $\operatorname{PKC~}(\alpha, \beta, \gamma, \delta$ e $\zeta)$ encontra-se em baixo nível no citoplasma e em alta concentração no fuso meiótico (exceto a PKC $\beta$ ) (RAZ et al., 1998; BALUCH et al., 2004). A fecundação induz a migração da PKC $\alpha, \beta$ e $\gamma$ para a membrana plasmática. Em contraste, as PKCs $\delta$ e $\zeta$ continuam associadas ao fuso meiótico e a inibição destas formas de PKC durante a ativação é acompanhada pela quebra do fuso (BALUCH et al., 2004; MA et al., 2008). Estes resultados sugerem que as PKCs participam da estabilidade do fuso em MII, mas não participam diretamente da retomada da meiose durante a Weber Beringui Feitosa 
fecundação, uma vez que a ativação induz a migração destas para a membrana. Adicionalmente, as PKCs que permanecem regulando o fuso meiótico são a PKC nova $(\delta)$ e a

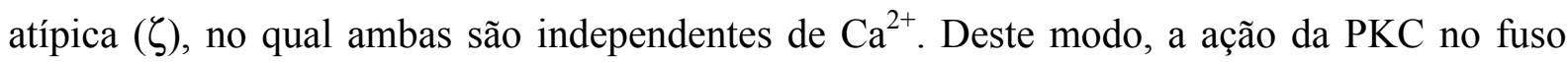
meiótico não é regulada diretamente pelo aumento da $\left[\mathrm{Ca}^{2+}\right] \mathrm{i}$ em resposta a ativação do oócito. Estes resultados também ajudam a explicar a diferença do papel da PKC na retomada da meiose, é plausível atribuir que o efeito da PKC na progressão pelo ciclo celular, observado em alguns trabalhos seja devido à ação das $\mathrm{PKCs} \delta$ e $\zeta$ no fuso meiótico e não uma ação das PKCs convencionais ativadas pelo $\mathrm{Ca}^{2+}$ na fecundação.

A PKC também participa da regulação dos filamentos de actina em uma variedade de tipos celulares (LARSON; 2006). Os oócitos em MII apresentaram uma distribuição homogênea dos filamentos de actina pelo citoplasma com acentuada localização na membrana plasmática. A ativação partenogenética induziu a reorganização dos filamentos de actina como observado pela alteração da intensidade de fluorescência emitida. Entretanto, a distribuição dos filamentos de actina no citoplasma foi alterada quando a atividade de PKC foi inibida. A mudança, mas significativa foi observada no citoplasma e não na membrana plasmática. É possível que a alta concentração de filamentos de actina na membrana plasmática e a forte fluorescência detectada nesta região possam mascarar algumas mudanças sutis. Outra possível explicação seria de que as proteínas ligadoras de actina, que ancoram os filamentos de actina à membrana plasmática estejam presentes de forma mais abundantes do que a actina citoplasmática. Os resultados do presente trabalho vão de encontro com os encontrados na literatura, no qual demonstram que a PKC regula os filamentos de actina (ELIYAHU et al., 2005, 2006).

Recentemente foi demonstrado que a reorganização do retículo endoplasmático (RE) é regulada pelos filamentos de actina e não pelos microtúbulos (FITZHARRIS et al., 2007). Como a PKC participa da regulação dos filamentos de actina durante a ativação do oócito, estando estes envolvidos na regulação de vários eventos (reorganização de organelas, migração e rotação do fuso meiotico) da maturação e da fecundação, este trabalho avaliou o papel da PKC na reorganização do RE.

Nos oócito em MII, o RE encontrava-se aglomerado (cluster) no córtex, contíguo à membrana plasmática. A ativação partenogenética induziu a reorganização do RE, passando a se localizar distribuído por todo o citoplasma. Entretanto, a reorganização do RE após a ativação partenogenética foi afetada pela inibição da PKC, que passou a se localizar em forte 
concentração junto à membrana plasmática. Estes resultados demonstram que a reorganização do RE durante a ativação é regulada pela PKC.

$\mathrm{Na}$ tentativa de correlacionar a ação da $\mathrm{PKC}$, a reorganização dos filamentos de actina e a reorganização do $\mathrm{RE}$ foram avaliadas a capacidade dos oócitos ativados partenogeneticamente na presença de citocalasina $\mathrm{D}$ sofrerem reorganização do RE.

A indução da despolimerização dos filamentos de actina com citocalasina $\mathrm{D}$ alterou a reorganização do RE endoplasmático após a ativação partenogenética. De forma semelhante ao que ocorreu na inibição da $\mathrm{PKC}$, na despolimerização dos filamentos de actina, o RE passou a se localizar em alta concentração próximo à membrana plasmática. Os resultados do presente trabalho demonstraram que a polimerização dos filamentos de actina coordenou a reorganização do RE na ativação partenogenética de oócitos de bovinos e que esta reorganização do RE é regulada pela $\mathrm{PKC}$.

Contudo, tem sido demonstrado que a PKC induz a despolimerização dos filamentos de actina, promovendo a exocitose dos grânulos corticais (ELIYAHU et al., 2005; TSAADON; KAPLAN-KRAICER; SHALGI, 2008). Estes resultados podem ser explicados pelo substrato no qual a PKC atua. Os substratos são mediadores centrais do efeito da PKC nos filamentos de actina. Entre os principais substratos da PKC, que atuam na regulação dos filamentos de actina estão as MARCKS, Adducin; Fascin e a proteína ERM.

A MARCKS é um importante fator de ancoramento dos filamentos de actina à membrana plasmática. A PKC fosforila a MARCKS, que por sua vez se desprende da membrana desorganizando os filamentos de actina ancorados à membrana plasmática (HARTWING et al., 1992).

A aducina cobre a extremidade do filamento de actina permitindo a ligação da espectrina à actina. A fosforilação da aducina pela $\mathrm{PKC}$ resulta na dissociação da aducina e da espectrina dos filamentos de actina expondo a extremidade na qual ocorre a polimerização. Deste modo, a ação PKC nos filamentos de actina via aducina, regula a polimerização destes filamentos (MATSUOKA; LI; BENNETT, 1998).

A fascina é uma proteína que une fortemente os feixes de actina e é importante na manutenção destas estruturas no citoplasma e em processos de protusões. A PKC fosforila a fascina que perde a capacidade de se ligar aos feixes de actina resultando na dissociação dos feixes (ADAMS et al., 1999).

As proteínas ERM (esrina, radixina e miosina) constituem um grupo de proteínas que tanto conecta os filamentos de actina com a membrana plasmática quanto participam como 
transdutores de sinais em diversas vias de sinalização. A ERM encontra-se inativa pelo citoplasma devido a interação do seu domínio N-terminal FERM com a parte C-terminal da proteína. A fosforilação pela PKC quebra esta interação abrindo o estado conformacional da proteína. O domínio FERM exposto interage com proteínas da membrana plasmática e o domínio C-terminal com os filamentos de actina. Com o estado conformacional aberto, a proteína ERM também interage com várias proteínas sinalizadoras, mas sempre sinalizando para alguma ação na membrana plasmática (SIMONS et al., 1998).

Deste modo, a despolimerização dos filamentos de actina pode ser devido à ação da PKC em algum substrato específico para este fim. De fato, recentemente foi demonstrado que a despolimerização dos filamentos de actina pela PKC resulta na exocitose dos grânulos corticais, sendo que ocorre pela ação desta proteína no substrato MARCS (ELIYAHU et al., 2005; TSAADON; KAPLAN-KRAICER; SHALGI, 2008). Assim, passa a ser plausível supor que enquanto a PKC induz a despolimerização dos filamentos de actina via substrato MARCKS, na regulação da exocitose dos grânulos corticais, também regula a polimerização dos filamentos de actina na reorganização do $\mathrm{RE}$ via outro substrato. Por regular a polimerização dos microfilamentos, a fascina seria o substrato de escolha para a ação da PKC na reorganização do RE após a ativação partenogenética.

Resultado semelhante do efeito da PKC na polimerização dos filamentos de actina tem sido descrito. A ativação da PKC com 12-O-tetradecanoilforbol-13-acetato (TPA) induz a polimerização dos filamentos de actina em oócitos de T. tubifex, enquanto o antagonista de PKC inibe a polimerização (TAKASHI, 1997).

O presente trabalho demonstrou que a PKC regula a reorganização do RE e que a reorganização do RE, após a ativação ocorre via polimerização dos filamentos de actina. Contudo experimentos adicionais necessitam ser realizados para unir a via PKC-actina-RE, principalmente para elucidar qual seria o substrato de ação da PKC para a polimerização dos filamentos de actina durante a reorganização do RE. 
N

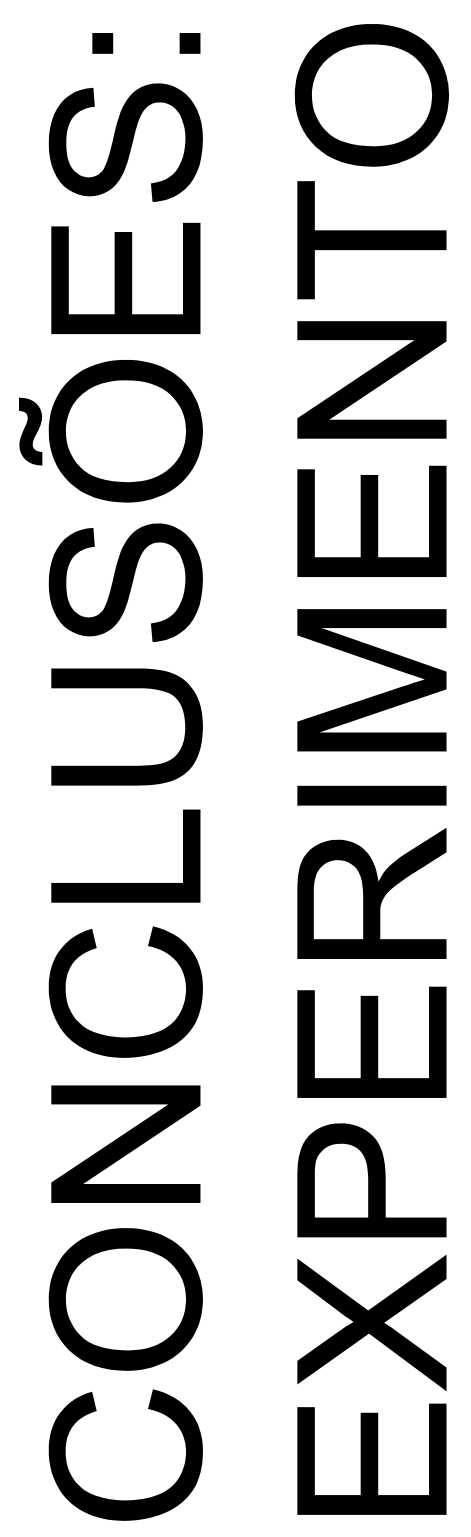




\section{CONCLUSÕES: EXPERIMENTO 2}

De acordo com os resultados apresentados, este trabalho permite concluir que:

1 - A PKC não participa da retomada da meiose em oócitos bovinos ativados partenogeneticamente.

2 - A organização dos microtúbulos não é regulada pela PKC.

3 - A PKC regula a organização dos filamentos de actina.

4 - A PKC regula a reorganização do RE.

5 - A reorganização do RE ocorre via polimerização dos filamentos de actina.

Baseado nas conclusões foi formulado o modelo hipotético gráfico apresentado na figura 12.

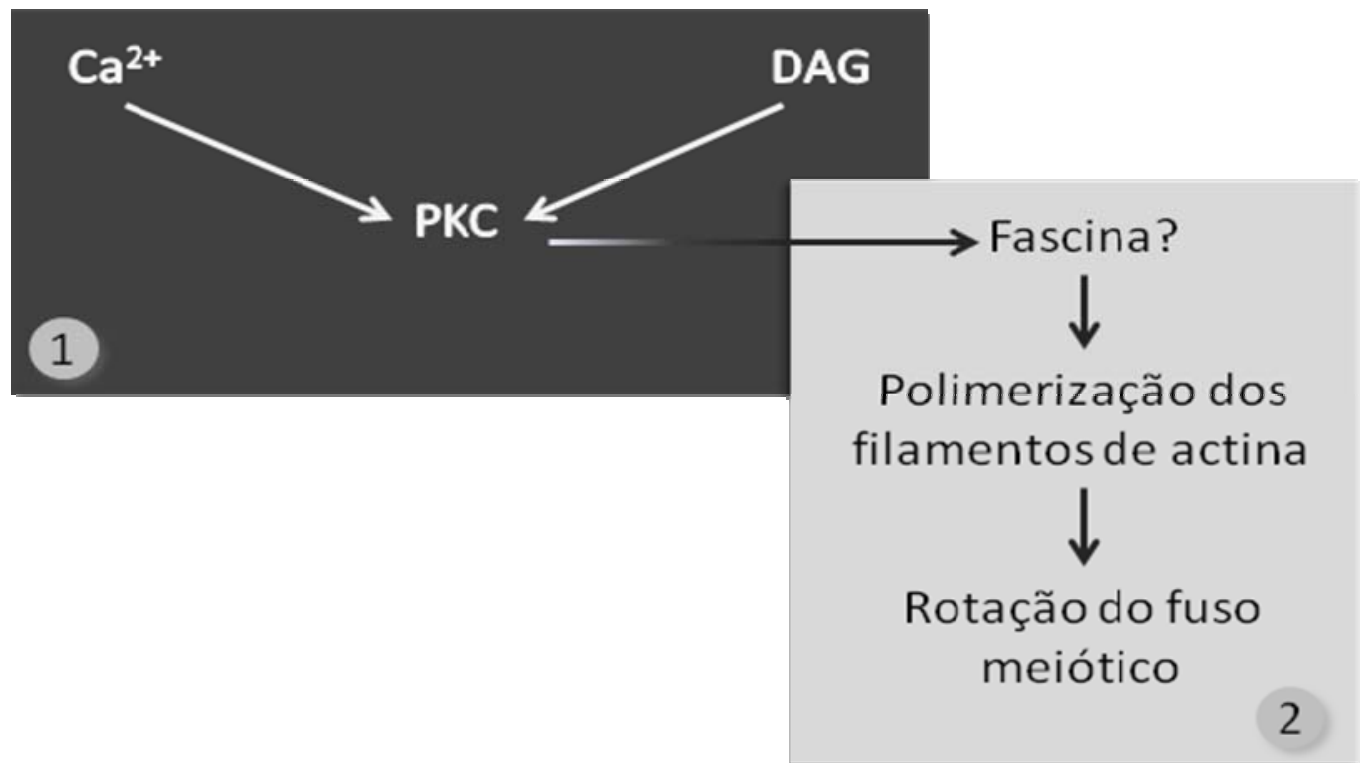

Figura 12 - Modelo hipotético gráfico da participação da PKC na ativação partenogenética de oócitos bovinos. 1 $-\mathrm{O} \mathrm{Ca}{ }^{2+}$ e o DAG se ligam à PKC. 2 - A PKC ativada regula a polimerização dos filamentos de actina que por sua vez são responsáveis pela reorganização do RE, após a ativação partenogenética. A ação da PKC nos filamentos de actina possivelmente ocorre por intermédio do substrato de PKC, fascina, conhecido por induzir polimerização dos filamentos de actina. Para confirmar esta hipótese, novos experimentos necessitam ser realizados 


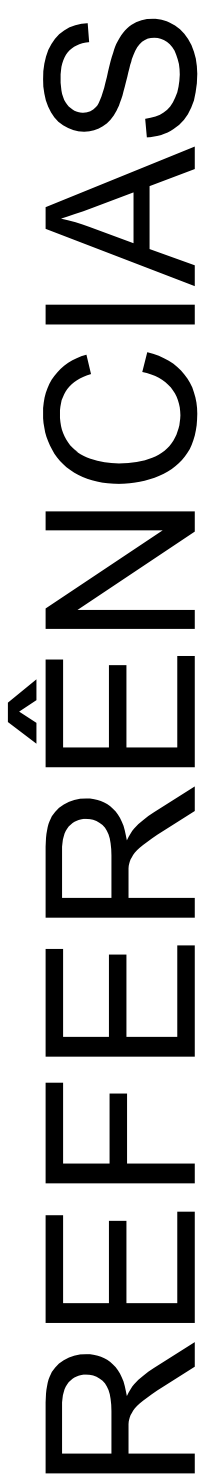




\section{REFERÊNCIAS}

ADAMS, J. C.; CLELLAND, J. D.; COLLETT, G. D. M.; MATSUMURA, F.; YAMASHIRO, S.; ZHANG, L. Cell-matrix adhesions differentially regulate fascin phosphorylation. Molecular Biology of the Cell, v. 10, p. 4177-4190, 1999.

BACKSA, J.; STEINB, P.; BACKSA, T.; DUNCAN, F. E.; GRUETER, C. E.; MCANALLY J.; QI, X.; SCHULTZ , R. M.; OLSON, E. N. The $\gamma$ isoform of CaM kinase II controls mouse egg activation by regulating cell cycle resumption. Proceedings of the National Academy of Sciences, v. 107, p. 81-86, 2010.

BAITINGER, C. J.; ALDERTON, M.; SCHULMAN, H.; STEINHARDT, R. Multifunctional $\mathrm{Ca} 2+/$ calmodulin-dependent protein kinase is necessary for nuclear envelope breakdown. Journal of Cell Biology, v. 111, p. 1763-1773, 1990.

BALUCH, D. P.; KOENEMAN, B. A.; HATCH, K. R.; MCGAUGHEY, R. W.; CAPCO, D. G. PKC isotypes in post-activated and fertilized mouse eggs: Association with the meiotic spindle. Developmental Biology, v. 274, p. 45-55, 2004.

BEDFORD, S. J.; KUROKAWA, M.; HINRICHS, K.; FISSORE, R. A. Intracellular calcium oscillations and activation in horse oocytes injected with stallion sperm extracts or spermatozoa. Reproduction, v. 126, p. 489-499, 2003.

BURGOYNE, R. D.; CHEEK, T. R.; O'SULLIVAN, A. J. The control of cytoskeletal actin and exocytosis in intact and permeabilized adrenal chromaffin cells: role of calcium and protein kinase C. Cellular Signaling, v. 1, p. 323-334, 1989.

CAPCO, D. G. Molecular and biochemical regulation of early mammalian development. International. Review of Cytology, v. 207, p. 195-235, 2001.

CAPCO, D. G.; TUTNICK, J. M.; BEMENT, W. M.; The role of protein kinase C in reorganization of the cortical cytoskeleton during the transition from oocyte to fertilizationcompetent egg. Journal of Experimental Zoology, v. 264, p. 395-405, 1992.

CHANG, H. Y.; MINAHAN, K.; MERRIMAN, J. A.; JONES, K. T. Calmodulin-dependent protein kinase gamma 3 (CamKII $\gamma 3$ ) mediates the cell cycle resumption of metaphase II eggs in mouse. Development, v. 136, p. 4077-4081, 2009. 
CHUNG, J. T.; KEEFER, C. L.; DOWNEY, R. B. Activation of bovine oocytes following intracytoplasmic sperm injection. Theriogenology, v. 53, p. 1273-1283, 2000.

COLBRAN, R. J. Targeting of calcium/calmodulin-dependent protein kinase II.

Biochemistry Journal, v. 378, p. 1-16, 2004.

COLONNA, R.; TATONE, C.; FRANCIONE, A.; ROSATI, F.; CALLAINI, G.; CORDA, D.; DI FRANCESCO, L. Protein kinase $\mathrm{C}$ is required for the disappearance of MPF upon artificial activation in mouse eggs. Molecular Reproduction and Development, v. 48, p. 292-299, 1997.

DOREE, M.; HUNT. T. From Cdc2 to Cdk1: When did the cell cycle kinase join its cyclin partner? Journal of Cell Science, v. 115, p. 2461-4464, 2002.

DUCIBELLA, T.; FISSORE, R. A. The roles of Ca2+, downstream protein kinases, and oscillatory signaling in regulating fertilization and the activation of development.

Developmental Biology, v. 315, p. 257-279, 2008.

DUCIBELLA, T.; KURASAWA, S.; DUFFY, P.; KOPF, G. S.; SCHULTS, R. M. Regulation of the polyspermy block in the mouse egg: maturation-dependent differences in cortical granule exocytosis and zona pellucida modifications induced by inositol 1,4,5-trisphosphate and an activator of protein kinase C. Biology of Reproduction, v. 48, p. 1251-1257, 1993.

ELIYAHU, E.; SHALGI, R. A role for protein kinase C during rat egg activation, Biology of Reproduction, v. 67, p. 189-195, 2002.

ELIYAHU, E.; SHTRAIZENT, N.; TSAADON, A.; SHALGI, R. Association between myristoylated alanin-richCkinase substrate (MARCKS) translocation and cortical granule exocytosis in rat eggs. Reproduction, v. 131, p. 221-231, 2006.

ELIYAHU, E.; TSAADON, A.; SHTRAIZENT, N.; SHALGI, R. The involvement of protein kinase $\mathrm{C}$ and actin filaments in cortical granule exocytosis in the rat. Reproduction, v. 129, p. 161-170, 2005.

FAN, H. Y.; HUO, L. J.; MENG, X. Q.; ZHONG, Z. S.; HOU, Y.; CHEN, D. Y.; SUN, Q. Y. Involvement of Calcium/Calmodulin-Dependent Protein Kinase II (CaMKII) in Meiotic Maturation and Activation of Pig Oocytes. Biology of reproduction, v. 69, p. 1552-1564, 2003. 
FAN, H. Y.; TONG, C.; LI, M. Y.; LIAN, L.; CHEN, D. Y.; SCHATTEN, H.; SUN, Q. Y. Translocation of the classic protein kinase $\mathrm{C}$ isoforms in porcine oocytes: implications of protein kinase $\mathrm{C}$ involvement in the regulation of nuclear activity and cortical granule exocytosis. Experimental Cell Research, v. 277, p. 183-191, 2002.

FAN, H. Y.; SUN, Q. Y. Involvement of Mitogen-Activated Protein Kinase Cascade During Oocyte Maturation e Fertilization in Mammals. Biology of Reproduction, v. 70, p. 535-547, 2004.

FITZHARRIS, G.; MARANGOS, P.; CARROLL, J. Cell cycle-dependent regulation of structure of endoplasmic reticulum and inositol 1,4,5-trisphosphateinduced Ca2 + release in mouse oocytes and embryos. Molecular Biology of the Cell, v. 14, p. 288-301, 2003.

FITZHARRIS, G.; MARANGOS, P.; CARROLL, J. Changes in endoplasmic reticulum structure during mouse oocyte maturation are controlled by the cytoskeleton and cytoplasmic dynein. Developmental Biology, v. 305, p. 133-144, 2007.

GALLICANO, G. I.; MCGAUGHEY, R. W.; CAPCO, D. G. Activation of protein kinase C after fertilization is required for remodeling the mouse egg into the zygote, Molecular Reproduction and Development, v. 46, p. 587-601, 1997.

GALLICANO, G. I.; MCGAUGHEY, R. W.; CAPCO, D. G. Cytoskeletal sheets appear as universal components of mammalian eggs. Journal of Experimental Zoology, v. 263, p. 194-203, 1992.

GALliCANO, G. I.; MCGAUGHEY, R. W.; CAPCO, D. G. Protein kinase M, the cytosolic counterpart of protein kinase $\mathrm{C}$, remodels the internal cytoskeleton of the mammalian egg during activation. Developmental Biology, v. 167, p. 482-501, 1995.

GALLICANO, G. I.; SCHWARTZ, S. M.; MCGAUGHEY, R. W.; CAPCO, D. G. Protein kinase $\mathrm{C}$, a pivotal regulator of hamster egg activation, functions after elevation of intracellular free calcuim. Developmental Biology, v. 156, p. 94-106, 1993.

GARDNER, A.J.; KNOTT, J.G.; JONES, K.T.; EVANS, J.P. CaMKII Can Participate in But Is Not Sufficient for the Establishment of the Membrane Block to Polyspermy in Mouse Eggs. Journal of Cell Physiology, v. 212, p. 275-280, 2007.

GRIECO, D.; PORCELlinI, A.; AVVEDIMENTO, E. V.; GOTTESMAN, M. E. Requirement for cAMP-PKA Pathway Activation by M Phase-Promoting Factor in the Transition from Mitosis to Interphase. Science, v. 271, p. 1719-1723, 1996. 
GRIFFITH, L. C. Regulation of Calcium/Calmodulin-Dependent Protein Kinase II Activation by Intramolecular and Intermolecular Interactions. Journal of Neuroscience, v. 24, p. 83948398, 2004.

HALET, G.; TUNWELL, R.; PARKINSON, S. J.; CARROLL, J. Conventional PKCs regulate the temporal pattern of $\mathrm{Ca} 2+$ oscillations at fertilization in mouse eggs. Journal of Cell Biology, v. 164, p. 1033-1044, 2004.

HANSEN, D. V.; TUNG, J. J.; JACKSON, P. K. CaMKII and polo-like kinase 1 sequentially phosphorylate the cytostatic factor Emi2/ XErp1 to trigger its destruction and meiotic exit. Proceedings of the National Academy of Sciences of the United States of America, v. 103, p. 608-613, 2006.

HARTWIG, J. H.; THELEN, M.; ROSEN, A.; JANMEY, P. A.; NAIRN, A. C.; ADEREM, A. MARCKS is an actin filament crosslinking protein regulated by protein kinase $\mathrm{C}$ and calcium-calmodulin. Nature, v. 356, p. 618-622, 1992.

INAGAKI, M.; GONDA, Y.; MATSUYAMA, M.; NISHIZAWA, K.; NISHI, Y.; SATO, C. Intermediate filament reconstitution in vitro. The role of phosphorylation on the assemblydisassembly of desmin. Journal of Biological Chemistry, v. 263, p. 5970-5978, 1987.

ITO, M.; SHIKANO, T.; KURODA, K.; MIYAZAKI, S. Relationship between nuclear sequestration of PLC_and termination of PLC $\zeta$-induced Ca2+ oscillations in mouse eggs. Cell Calcium, v. 44, p. 400-410, 2008

ISHIDA, A.; KAMESHITA, I.; OKUNO, S.; KITANI, T.; FUJIWARA, H. A novel highly specific and potent inhibitor of calmodulin-dependent protein kinase II. Biochemical and Biophysical Research Communications, v. 212, p. 806-812, 1995.

ITO, J.; SHIMADA, M.; TERADA, T. Effect of protein kinase C activator on mitogenactivated protein kinase e p34 ${ }^{\mathrm{cdc} 2}$ kinase activity during parthenogenetic activation of porcine oocytes by calcium ionophore. Biology of Reproduction, v. 69, p. 1675-1682, 2003.

JAFFE, L.A.; TERASAKI, M. Structural changes of the endoplasmic reticulum of starfish oocytes during meiotic maturation and fertilization. Development Biology, v. 164, p. 579$587,1994$.

JOHNSON, J.; BIERLE, B. M.; GALLICANO, G. I.; CAPCO, D. G. Calcium/calmodulindependent protein kinase II and calmodulin: regulators of the meiotic spindle in mouse eggs. Developmental Biology, v. 204, p. 464-477, 1998. 
JONES, K. T. Protein kinase C action at fertilization: overstated or undervalued? Reviews of Reproduction, v. 3, p. 7-12, 1998.

JONES, K. T. Turning it on and off: M-phase promoting factor during meiotic maturation and fertilization. Molecular Human Reproduction, v. 10, p. 1-5, 2004

JONES, K. T.; CARROLL, J.; MERRIMAN, J. A.; WHITTINGHAM, D. G.; KONO, T. Repetitive sperm-induced $\mathrm{Ca} 2+$ transients in mouse oocytes are cell cycle dependent.

Development, v. 121, p. 3259-3266, 1995.

JONES, K. T. Intracellular calcium in the fertilization development of mammalian eggs.

Clinical and experimental pharmacology \& physiology, v. 34, p. 1084-1089, 2007.

KLINE, D. Attributes and dynamics of the endoplasmic reticulum in mammalian eggs. Current Topics in Developmental Biology, v. 50, p. 125-154, 2000.

KNOTT, J. G.; GARDNER, A. J.; MADGWICKM, S.; JONESM K.T.; WILLIAMS, C. J.; SCHULTZ, R. M. Calmodulin-dependent protein kinase II triggers mouse egg activation and embryo development in the absence of $\mathrm{Ca}^{2+}$ oscillations. Developmental Biology, v. 296, p. 388-395, 2006.

KNOTT, J. G.; KUROKAWA, M.; FISSORE, R. A. Release of the $\mathrm{Ca}^{2+}$ oscillation-inducing sperm factor during mouse fertilization. Developmental Biology, v. 260, p. 536-547, 2003

KNOTT, J. G.; KUROKAWA, M.; FISSORE, R. A.; SCHULTZ, R. M.; WILLIAMS, C. J. Transgenic RNA interference reveals role for mouse sperm phospholipase $\mathrm{C}$ zeta in triggering $\mathrm{Ca}^{2+}$ oscillations during fertilization. Biology of Reproduction, v. 72, p. 992-996, 2005.

KNOTT, J. G.; POOTHAPILLAI, K.; WU, H.; HE, C. L.; FISSORE, R. A.; ROBL, J.M. Porcine sperm factor supports activation and development of bovine nuclear transfer embryos. Biology of Reproduction, v. 66, p. 1095-1103, 2002.

KOUCHI, Z.; FUKAMI, K.; SHIKANO, T.; ODA, S.; NAKAMURA, Y.; TAKENAWA, T.; MIYAZAKI, S. Recombinant phospholipase $\mathrm{C}$ zeta has high $\mathrm{Ca}^{2+}$ sensitivity and induces $\mathrm{Ca}^{2+}$ oscillations in mouse eggs. Journal of biological chemistry, v. 279, p. 10408-10412, 2004.

LARSSON, C. Protein kinase $\mathrm{C}$ and the regulation of the actin cytoskeleton. Cellular Signaling, v. 18, p. 276-284, 2006 
LEE, J.; MIYANO, T.; MOOR, R. Spindle formation e dynamics of $\gamma$-tubulin e nuclear mitotic apparatus protein distribution during meiosis in pig e mouse oocytes. Biology of Reproduction, v. 62, p. 1184-1192, 2000.

LEITGES, M.; MAYR, M.; BRAUN, U.; MAYR, U.; LI, C.; PFISTER, G.; GHAFFARITABRIZI, N.; BAIER, G.; HU, Y.; XU, Q. Exacerbated vein graft arteriosclerosis in protein kinase Cdelta-null mice. Journal of Clinical Investigation, v. 108, p. 1505-1512, 2001.

LELKES, P. I.; FRIEDMAN, J. E.; ROSENHECK, K.; OPLATKA, A. Destabilization of actin filaments as a requirement for the secretion of catecholamines from permeabilized chromaffin cells. FEBS Letter, v. 208, p. 357-363, 1986.

LIU, J.; MALLER, J. L. Calcium elevation at fertilization coordinates phosphorylation of XErp1/Emi2 by Plx1 e CaMK II to release metaphase arrest by cytostatic factor. Current Biology, v. 15, p. 1458-1468, 2005.

LIU, L.; JU, J.C.; YANG, X. Differential inactivation of maturation-promoting factor and mitogen-activated protein kinase following parthenogenetic activation of bovine oocytes.

Biology of Reproduction, v. 59, p. 537-545, 1998.

LIU, L.; TRIMARCHI, J.; OLDENBOURG, R.; KEEFE, D. Increased birefringence in the meiotic spindle provides a new marker for the onset of activation in living oocytes. Biology of Reproduction, v. 63, p. 251-258, 2000.

LORCA, T.; CRUZALEGUL, F. H.; FESQUET, D.; CAVADORE, J.C.; MERY, J.; MEANS, A.; DOREE, M. Calmodulin-dependent protein kinase II mediates inactivation of MPF and CSF upon fertilization of Xenopus eggs. Nature, v. 366, p. 270-273, 1993.

LURIA, A.; TENNENBAUM, T.; SUN, Q. Y.; RUBINSTEIN, S.; BREITBART, H. Differential localization of conventional protein kinase $\mathrm{C}$ isoforms during mouse oocyte development. Biology of Reproduction, v. 62, p. 1564-1570, 2000.

MA, W.; KOCH, J. A.; VIVEIROS, M. M. Protein kinase C delta (PKCdelta) interacts with microtubule organizing center (MTOC)-associated proteins and participates in meiotic spindle organization. Developmental Biology, v. 320, p. 414-425, 2008.

MACHÁTY, Z.; BONK, A. J.; KÜHHOLZER, B.; PRATHER, R. S. Porcine oocyte activation induced by a cytosolic sperm factor. Molecular, Reproduction and Development, v. 57, p. 290-295, 2000. 
MACKAY, H. J.; TWELVES, C. J. Targeting the protein kinase C family: are we there yet? Nature, v. 7, p. 554-567, 2007.

MADGWICK, S.; LEVASSEUR, M.; JONES, K. T. Calmodulin-dependent protein kinase II, and not protein kinase $\mathrm{C}$, is sufficient for triggering cell-cycle resumption in mammalian eggs. Journal of Cell Science, v. 118, p. 3849-3859, 2005.

MALCUIT, C.; MASERATI, M.; TAKAHASHI, Y.; PAGE, R.; FISSORE, R. A. Intracitoplasmic sperm injection in the bovine induces abnormal $\left[\mathrm{Ca}^{2+}\right]$ responses and oocyte activation. Reproduction Fertility and Development, v. 18, p. 39-51, 2006

MARÍN-BRIGGILER, C. I.; JHA, K. N.; CHERTIHIN, O.; BUFFONE, M. G.; HERR, J. C.; VAZQUEZ-LEVIN, M. H.; VISCONTI, P. E. Evidence of the presence of calcium/calmodulin-dependent protein kinase IV in human sperm and its involvement in motility regulation. Evidence of the presence of calcium/calmodulin-dependent protein kinase IV in human sperm and its involvement in motility regulation. Journal of Cell Science, v. 118, p. 2013-2022, 2005.

MARKOULAKI, S.; MATSON, S.; ABBOTT, A. L.; DUCIBELLA, T. Oscillatory CaMKII activity in mouse egg activation. Developmental Biology, v. 258, p. 464-474, 2003.

MARKOULAKI, S.; MATSON, S.; DUCIBELLA, T. Fertilization stimulates long-lasting oscillations of CaMKII activity in mouse eggs. Developmental Biology, v. 272, p. 15-25, 2004.

MATSON, S.; MARKOULAKI, S.; DUCIBELLA, T. Antagonists of Myosin Light Chain Kinase and of Myosin II Inhibit Specific Events of Egg Activation in Fertilized Mouse Eggs. Biology of Reproduction, v. 74, p. 169-176, 2006.

MATSUOKA, Y.; LI, X.; BENNETT, V. Adducin is an in vivo substrate for protein kinase $\mathrm{C}$ : phosphorylation in the MARCKS-related domain inhibits activity in promoting spectrinactin complexes and occurs in many cells, including dendritic spines of neurons. Journal of cell biology, v. 142, p. 485-497, 1998.

MEHLMANN, L. M.; TERASAKI, M.; JAFFE, L. A.; KLINE, D. Reorganization of the endoplasmic reticulum during meiotic maturation of the mouse oocyte. Developmental Biology, v. 170, p. 607-15, 1995.

MILAZZOTTO, M. P.; PAULA-LOPES, F. F.; GOISSIS, M. D.; PERES, M. A.; SIMÕES, R.; GONSALVES, J. S. A.; NICACIO, A. C.; VISINTIN, J. A. ASSUMPCAO, M. E. O.D. Efeito do tempo de exposição aos espermatozóides nos índices de fecundação in vitro de Weber Beringui Feitosa 
oócitos bovinos maturados após remoção das células do cumulus. Acta Scientiae Veterinariae, v. 36, p. 571, 2008. Suplemento. Trabalho apresentado á XXII Reunião Anual da Sociedade Brasileira de Tecnologia de Embriões, Guarujá, 2008.

MOOS, J.; VISCONTI, P. E.; MOORE, D. G.; SCHULTZ, R. M.; KOPF, G. S. Potential role of mitogenactivated protein kinase in pronuclear envelope assembly and disassembly following fertilization of mouse eggs. Biology of Reproduction, v. 53, p. 692-699, 1995.

MUALLEM, S.; KWIATKOWASKA, K.; XU, X.; YIN, H. L. Actin filament disassembly is a sufficient final trigger for exocytosis in nonexcitable cells. Journal of Cell Biology, v. 128, p. 589-598, 1995.

NAVARRO, P. A.; LIU, L.; TRIMARCHI, J. R.; FERRIANI, R. A.; KEEFE, D. L. Noninvasive imaging of spindle dynamics during mammalian oocyte activation. Fertility and Sterility, v. 83, p. 1197-1205, 2005.

NEWTON, A. C. Protein kinase C; structure, function, and regulation. Journal of Biology and Chemistry, v. 270, p. 28495-28498, 1995.

NIXON, V. L.; LEVASSEUR, M.; MCDOUGALL, A.; JONES, K. T. $\mathrm{Ca}^{2+}$ oscillations $^{2}$ promote APC/C-dependent cyclin B1 degradation during metaphase arrest and completion of meiosis in fertilizing mouse eggs. Current Biology, v. 12, p. 746-750, 2002.

NISHIZUKA, Y. Intracellular signalling by hydrolysis of phospholipids and activation of protein kinase C. Science, v. 258, p. 607-614, 1992.

OANCEA, E.; MEYER, T. Protein kinase $\mathrm{C}$ as a molecular machine for decoding calcium and diacylglycerol signals. Cell, v. 95, p. 307-318, 1998.

PAYNE, C.; SCHATTEN, G. Golgi dynamics during meiosis are distinct from mitosis and are coupled to endoplasmic reticulum dynamics until fertilization. Developmental Biology, v. 264, p. 50-63, 2003.

PETERS, J. M. The anaphase promoting complex/cyclosome: A machine designed to destroy. Nature. Reviews. Molecular Cell Biology, v. 7, p. 644-656, 2006.

RAZ, T.; BEN-YOSEF, D.; SHALGI, R. Segregation of the pathways leading to cortical reaction and cell cycle activation in the rat egg. Biology of Reproduction, v. 58, p. 94-102, 1998. 
RAZ, T.; ELIYAHU, E.; YESODI, V.; SHALGI, R. Profile of protein kinase C isoenzymes and their possible role in mammalian egg activation. FEBS Letters, v. 431, p. 415-418, 1998.

RHO, G. J.; KAWARSKY, S.; JOHNSON, W. H.; KOCHHAR, K.; BETTERIDGE, K. Sperm and oocytes treatments to improve the formation of male and female pronuclei and subsequent development following intracytoplasmic sperm injection into bovine oocytes. Biology of Reproduction, v. 59, p. 918-924, 1998.

RUNFT, L. L.; JAFFE, L. A.; MEHLMANN, L. M. Egg activation at fertilization: Where it all begins. Developmental Biology, v. 245, p. 237-254, 2002.

SWANN, K. Soluble sperm factors and Ca2+ release in eggs at fertilization. Reviews of Reproduction, v. 1, p. 33-39, 1996.

SAUNDERS, C. M.; LARMAN, M. G.; PARRINGTON, J.; COX, L. J.; ROYSE, J.; BLAYNEY, L. M.; SWANN, K.; LAI, F. A. PLC zeta: A sperm-specific trigger of $\mathrm{Ca}^{(2+)}$ oscillations in eggs and embryo development. Development, v. 129, p. 3533-3544, 2002.

SCHENK, P. W.; SNAAR-JAGALSKA, B. E. Signal perception and transduction: the role of protein kinases. Biochemistry Biophysics Acta, v. 1449, p. 1-24, 1999.

SCHULTZ, R. M.; KOPF, G. S. Molecular basis of mammalian oocyte activation. Current Topics in Developmental Biology, v. 30, p. 21-61, 1995.

SIMONS, P. C.; PIETROMONACO, S. F.; RECZEK, D.; BRETSCHER, A.; ELIAS, L. Cterminal threonine phosphorylation activates ERM proteins to link the cell's cortical lipid bilayer to the cytoskeleton. Biochemical and biophysical research communications, v. 253, p. 561-565, 1998.

SHIRAI, Y.; SAITO, N. Activation mechanisms of protein kinase c: maturation, catalytic activation, and targeting. Journal of biochemistry, v. 132, p. 663-668, 2002.

SHIRAISHI, K.; OKADA, A.; SHIRAKAWA, H.; NAKANISHI, S.; MIKOSHIBA, K.; MIYAZAKI, S. Developmental changes in the distribution of the endoplasmic endoplasmicreticulum and inositol 1,4,5-trisphosphate receptors and the spatial pattern of $\mathrm{Ca}^{2+}$ release during maturation of hamster oocytes. Developmental Biology, v. 170, p. 594-606, 1995. SONTAG, J. M.; AUNIS, D.; BADER, M. F. Peripheral actin filaments control calciummediated catecholamine release from streptolysin-opermeabilized chromaffin cells.

European Journal of Cell Biology, v. 46, p. 316-326, 1988.

Weber Beringui Feitosa 
STRICKER, S. A. Comparative biology of calcium signaling during fertilization and egg activation in animals. Developmental Biology, v. 211, p. 157-176, 1999.

SUN, Q. Y.; LAI, L.; PARK, K. W.; KÜHHOLZER, B.; PRATHER, R.; SCHATTEN, H. Dynamic events are differently mediated by microfilaments, microtubules, e mitogenactivated protein kinase during porcine oocyte maturation e fertilization. Biology of Reproduction, v. 64, p. 879-889, 2001.

SUN, Q. Y.; RUBINSTEIN, S.; BREITBART, H. MAP kinase activity is downregulated by phorbol ester during mouse oocyte maturation e egg activation in vitro. Molecular, Reproduction and Development, v. 52, p. 310-318, 1999.

SUTOVSKY, P.; MANANDHAR, G.; WU, A.; OKO, R. Interactions of sperm perinuclear theca with the oocyte: implications for oocyte activation, anti-polyspermy defense, and assisted reproduction. Microscopy, Research and Techniques, v. 61, p. 362-378, 2003.

SUTTNER, R.; ZAKHARTCHENKO, V.; STOJKOVITC, P.; MULLER, ALBERIO, R.; MEDJUGORAC, I.; BREM, G.; WOLF, E.; STOJKOVIC, M. Intracytoplasmic sperm injection in bovine: effects of oocyte activation, sperm pre-treatment and injection technique. Theriogenology, v. 54, p. 935-948, 2000.

TAKASHI, S. Reorganization of the cortical actin cytoskeleton during maturation division in the Tubifex egg: possible involvement of protein kinase C. Developmental Biology, v. 188, p. 110-121, 1997.

TATONE, C.; DELLE MONACHE, S.; FRANCIONE, A.; GIOIA, L.; BARBONI, B.; COLONNA, R. $\mathrm{Ca}^{2+}$-independent protein kinase $\mathrm{C}$ signaling in mouse eggs during the early phases of fertilization. International Journal of Developmental Biology, v. 47, p. 327-333, 2003.

TATONE, C.; MONACHE, S. D.; IORIO, R.; CASERTA, D.; COLA, M. D.; COLONNA, R. Possible role for $\mathrm{Ca}^{2+} /$ calmodulin-dependent protein kinase II as an effector of the fertilization $\mathrm{Ca}^{2+}$ signal in mouse oocyte activation. Molecular Human Reproduction, v. 8, p. 750-757, 2002.

TERADA, Y.; SIMERLY, C.; SCHATTEN, G. Microfilament stabilization by jasplakinolide arrests oocyte maturation, cortical granule exocytosis, sperm incorporation cone resorption, and cell-cycle progression, but not DNA replication, during fertilization in mice. Molecular Reproduction and Development, v. 56, p. 89-98, 2000. 
TERASAKAI, M.; JAFFE, L.A. Organization of the sea urchin egg endoplasmic reticulum and its reorganization at fertilization. Journal of Cell Biology, v. 114, p. 929-40, 1991.

TERASAKI, M.; RUNFT, L. L.; HAND, A. R. Changes in organization of the endoplasmic reticulum during Xenopus oocyte maturation and activation. Molecular Biology of the Cell, v. 12, p. 1103-1116, 2001.

TRIFARO, J. M.; VITALE, M. L.; RODRIGUEZ DEL CASTILLO, A. Cytoskeleton and molecular mechanisms in neurotransmitter release by neurosecretory cells. European

Journal of Pharmacology, v. 225, p. 83-104, 1992.

TSAADON, L.; KAPLAN-KRAICER, R.; SHALGI, R. Myristoylated alanine-rich C kinase substrate, but not $\mathrm{Ca} 2 \mathrm{C} /$ calmodulin-dependent protein kinase II, is the mediator in cortical granules exocytosis. Reproduction, v. 135, p. 613-624, 2008.

VITALE, M. L.; RODRIGUEZ DEL CASTILLO, A.; TCHAKAROV, L.; TRIFARO, J. M. Cortical filamentous actin disassembly and scinderin redistribution during chromaffin cell stimulation precede exocytosis: a phenomenon not exhibited by gelsolin. Journal of Cell Biology, v. 113, p. 1057-1067, 1991.

VIVEIROS, M. M.; O’BRIEN, M.; WIGGLESWORTH, K.; EPPIG, J. J. Characterization of protein kinase $\mathrm{C}$-delta in mouse oocytes throughout meiotic maturation and following egg activation. Biology of Reproduction, v. 69, p. 1494-1499, 2003.

ZHU, Z. Y.; CHEN, DY.; L. I, JS.; L. I, L.; LEI, L.; HAN, Z. M.; SUN, Q. Y. Rotation of meiotic spindle is controlled by microfilaments in mouse oocytes. Biology of Reproduction, v. 68, p. 943-946, 2003.

WANG, W. H.; ABEYDEERA, L. R.; PRATHER, R. S.; DAY, B. N. Polymerization of nonfilamentous actin into microfilaments is an important process for porcine oocyte maturation and early embryo development. Biology of Reproduction, v. 62, p. 1177-1183, 2000 .

WATANABE, N.; HUNT, T.; IKAWA, Y.; SAGATA, N. Independent inactivation of MPF and cytostatic factor (Mos) upon fertilization of Xenopus eggs. Nature, v. 352, p. 247-248, 1991.

WINSTON, N. J.; MARO, B. Calcium-dependent protein kinase II is activated transiently in ethanol-stimulated mouse oocytes. Developmental Biology, v. 170, p. 350-352, 1995. 
WINSTON, N. J.; MCGUINNESS, O.; JOHNSON, M.; MARO, B. The exit of mouse oocyte from meiotic $\mathrm{M}$-phase requires an intact spindle during intracellular calcium release. Journal of Cell Science, v. 108, p. 143-151, 1995.

XU, Z.; KOPF, G. S.; SCHULTZ, R. M. Involvment of inositol 1,4,5-triphosphate-mediated $\mathrm{Ca} 2+$ release in early and late events of mouse egg activation. Development, v. 120, p. 1851$1859,1994$.

YOO, J. G.; SMITH, L. C. Extracellular calcium induces activation of $\mathrm{Ca}^{2+} /$ calmodulindependent protein kinase II and mediates spontaneous activation in rat oocytes. Biochemical and Biophysical Research Communications, v. 359, p. 854-859, 2007.

YU, Y.; HALET, G.; LAI, F. A; SWANN, K. Regulation of diacylglycerol production and protein kinase $\mathrm{C}$ stimulation during sperm- and PLCzeta-mediated mouse egg activation. Biology of the Cell, v. 100, p. 633-643, 2008. 


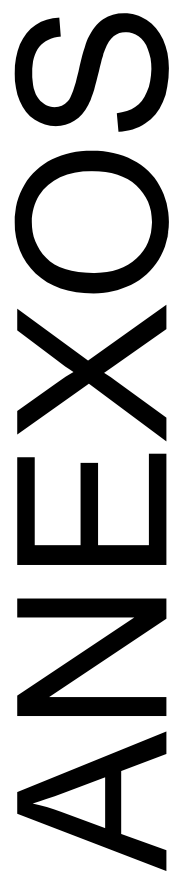


ANEXO A

\begin{tabular}{|lll|}
\hline & Meio de Fatiamento & \\
\hline Reagente & Quantidade & Marca/código \\
TCM 199 bicarbonato & $200 \mathrm{~mL}$ & Gibco / 31100-035 \\
Soro Fetal Bovino & $2 \mathrm{~mL}$ & Nutricell \\
Solução de Gentamicina & $200 \mu \mathrm{L}$ & Sigma/ G1264 \\
\hline Uso diário & & \\
\hline
\end{tabular}

\begin{tabular}{|lll|}
\hline & Meio de Lavagem & \\
\hline Reagente & Quantidade & Marca/código \\
TCM 199 bicarbonato & $4,5 \mathrm{~mL}$ & Gibco / 11150-59 \\
Soro Fetal Bovino & $0,5 \mathrm{~mL}$ & Gibco/ 12657-029 \\
Solução de piruvato & $10 \mu \mathrm{L}$ & Sigma/ P-3662 \\
Solução de Gentamicina & $25 \mu \mathrm{L}$ & Sigma/ G1264 \\
\hline Uso diário & & \\
\hline
\end{tabular}

\begin{tabular}{|lll|}
\hline & Meio de maturação & \\
\hline Reagente & Quantidade & Marca/código \\
TCM 199 com hepes & $4,5 \mathrm{~mL}$ & Gibco/ 12350-099 \\
Soro Fetal Bovino & $0,5 \mathrm{~mL}$ & Gibco/ 12657-029 \\
Solução de piruvato & $10 \mu \mathrm{L}$ & Sigma/ P-3662 \\
Solução de Gentamicina & $25 \mu \mathrm{L}$ & Sigma/ G1264 \\
Solução de FSH & $5 \mu \mathrm{L}$ & Bioniche \\
Solução de LH & $50 \mu \mathrm{L}$ & Intervet/057176 \\
Solução de estradiol & $5 \mu \mathrm{L}$ & Sigma/ E-4389 \\
\hline Estabilizar em estufa de $\mathrm{CO}_{2}$ por 2-3 horas. Uso diário & \\
\hline
\end{tabular}

Solução de gentamicina $10 \mathrm{mg} / \mathrm{mL}$

\begin{tabular}{|lll|}
\hline Reagente & Quantidade & Marca/código \\
Gentamicina & $0,1 \mathrm{~g}$ & Sigma / G-1264 \\
$\mathrm{NaCl} \mathrm{0,9 \%}$ & $10 \mathrm{~mL}$ & Beker \\
\hline Armazenar a $-20{ }^{\circ} \mathrm{C}$; Validade: 6 meses & \\
\hline
\end{tabular}

\begin{tabular}{|lll|}
\hline \multicolumn{3}{|c|}{ Solução de piruvato 0,2 $\mathrm{mM}$} \\
\hline Reagente & Quantidade & Marca/código \\
Piruvato & $0,1320 \mathrm{~g}$ & Sigma / P-4562 \\
$\mathrm{NaCl} 0,9 \%$ & $12 \mathrm{~mL}$ & Beker \\
\hline Armazenar a $-20{ }^{\circ} \mathrm{C}$; Validade: 6 meses & \\
\hline
\end{tabular}




\begin{tabular}{|lll|}
\hline \multicolumn{3}{c|}{ Solução de estradiol $1 \mu \mathrm{g} / \mathrm{mL}$} \\
\hline Reagente & Quantidade & Marca/código \\
Estradiol & $0,02041 \mathrm{~g}$ & Sigma / E-4389 \\
Água MiliQ & $1 \mathrm{~mL}$ & --------- \\
\hline Armazenar a $-20^{\circ} \mathrm{C}$; Validade: 6 meses & \\
\hline
\end{tabular}

\begin{tabular}{|lll|}
\hline \multicolumn{3}{|c|}{ Solução de FSH (Estoque) } \\
\hline Reagente & Quantidade & Marca/código \\
Folltropin & $400 \mathrm{mg}$ & Bioniche \\
$\mathrm{NaCl} 0,9 \%$ & $2 \mathrm{~mL}$ & Beker \\
\hline Armazenar a $-20{ }^{\circ} \mathrm{C}$; Validade: 6 meses & \\
\hline
\end{tabular}

\begin{tabular}{|c|c|c|}
\hline \multicolumn{3}{|c|}{ Solução de FSH (uso) $0,5 \mathrm{mg} / \mathrm{mL}$} \\
\hline Reagente & Quantidade & Marca/código \\
\hline Solução estoque & $50 \mu \mathrm{L}$ & ---------- \\
\hline TCM-199 Sodium bicarbonato & $20 \mathrm{~mL}$ & Gibco / 11150-59 \\
\hline
\end{tabular}

\begin{tabular}{|lll|}
\hline \multicolumn{3}{|c|}{ Solução de LH $700 \mathrm{UI} / \mathrm{mL}$} \\
\hline Reagente & Quantidade & Marca/código \\
Chorulon & $5000 \mathrm{UI}$ & Intervet/ 057176 \\
TCM-199 Sodium bicarbonato & 7,14 & Gibco / 11150-59 \\
\hline Armazenar a $-20{ }^{\circ} \mathrm{C}$; Validade: 6 meses & \\
\hline
\end{tabular}


ANEXO B

\begin{tabular}{|lll|}
\hline \multicolumn{1}{c|}{ SOF (Estoque) } \\
\hline Reagente & Quantidade & Marca/código \\
$\mathrm{NaCl}$ & $0,6294 \mathrm{~g}$ & Sigma / S-9625 \\
$\mathrm{KCl}$ & $0,0534 \mathrm{~g}$ & Sigma / P-4504 \\
$\mathrm{KH}_{2} \mathrm{PO}_{4}$ & $0,0162 \mathrm{~g}$ & Sigma / P-5655 \\
$\mathrm{NaHCO}_{3}$ & $0,2106 \mathrm{~g}$ & Sigma / S-5761 \\
$\mathrm{Na} \mathrm{Lactato}$ & $0,0370 \mathrm{~g}$ & Sigma / L-7900 \\
Ácido pirúvico & $0,0034 \mathrm{~g}$ & Sigma/ P-3662 \\
Phenol red & $0,00013 \mathrm{~g}$ & Sigma / P-4633 \\
$\mathrm{L}-\mathrm{glutamina}$ & $0,0146 \mathrm{~g}$ & Sigma / G-1517 \\
$\mathrm{MgCl}_{2}$ & $0,0098 \mathrm{~g}$ & Sigma/ M2393 \\
$\mathrm{CaCl}_{2}$ & $0,0252 \mathrm{~g}$ & Sigma/ C5670 \\
\hline Armazenar $8{ }^{\circ} \mathrm{C} ;$ Validade: 2 meses & & \\
\hline
\end{tabular}

\begin{tabular}{|lll|}
\hline \multicolumn{2}{c|}{ SOF (Uso) } \\
\hline Reagente & Quantidade & Marca/código \\
SOF estoque & $4,5 \mathrm{~mL}$ & ----- \\
Soro Fetal Bovino & $0,25 \mathrm{~mL}$ & Gibco / 12657-029 \\
Amino ácidos essenciais & $100 \mu \mathrm{L}$ & Sigma / M-5550 \\
Amino ácidos não essenciais & $50 \mu \mathrm{L}$ & Sigma / M-7145 \\
\hline Armazenar a $8{ }^{\circ}$ C; Validade: 1 semana & \\
\hline
\end{tabular}

\section{Solução de cálcio ionóforo (1 mM) (Estoque)}

\section{Reagente}

Calcium Ionophore A23187

DMSO

\section{Quantidade}

$5 \mathrm{mg}$

$10 \mathrm{ml}$
Marca/código

Sigma/ C-7522

Sigma/ D-2650

Armazenar a $-20^{\circ} \mathrm{C}$; Validade: 6 meses 


\section{ANEXO C}

\begin{tabular}{|lll|}
\hline \multicolumn{2}{|c|}{ Solução de inibição da CaMKII $(1 \mathrm{mM})$} \\
\hline Reagente & Quantidade & Marca/código \\
Autocamtide-2 Related Inhibitory Peptide, Myristoylated & $500 \mu \mathrm{g}$ & Merck/ 189482 \\
Água Milli Q & $292,7 \mu \mathrm{L}$ & --------- \\
\hline Armazenar a $-20{ }^{\circ} \mathrm{C}$; Validade: 3 meses & \\
\hline
\end{tabular}

\begin{tabular}{|lcc|}
\hline \multicolumn{3}{|c|}{ Solução de inibição da PKC $(10 \mathrm{mM})$} \\
\hline Reagente & Quantidade & Marca/código \\
Bisindolylmaleimide I & $1 \mathrm{mg}$ & Merck/ 203290 \\
DMSO & $242 \mu \mathrm{L}$ & Sigma/ D-2650 \\
\hline Armazenar a $-20{ }^{\circ} \mathrm{C}$; Validade: 6 meses & \\
\hline
\end{tabular}

\begin{tabular}{|lcc|}
\hline \multicolumn{3}{|c|}{ Solução de citocalasina B (estoque) } \\
\hline Reagente & Quantidade & Marca/código \\
Citocalasina B & $0,005 \mathrm{~g}$ & Sigma/ C-6762 \\
PBS & $1 \mathrm{~mL}$ & \\
\hline Armazenar a $-20{ }^{\circ} \mathrm{C}$; Validade: 6 meses & \\
\hline
\end{tabular}

\begin{tabular}{|lcc|}
\hline & Solução de citocalasina B (diluição 1) \\
\hline Reagente & Quantidade & Marca/código \\
Citocalasina B (estoque) & $50 \mu \mathrm{L}$ & \\
SOF & $950 \mu \mathrm{L}$ & \\
\hline Usar no dia & & \\
\hline
\end{tabular}

\begin{tabular}{|lll|}
\hline \multicolumn{3}{|c|}{ Solução de citocalasina B (diluição 2) (uso) } \\
\hline Reagente & Quantidade & Marca/código \\
Citocalasina B (diluilção 1) & $20 \mu \mathrm{L}$ & \\
SOF & $980 \mu \mathrm{L}$ & \\
\hline Usar no dia & & \\
\hline
\end{tabular}


ANEXO D

\begin{tabular}{|llll|}
\hline \multicolumn{3}{c|}{ Solução de PBS } \\
\hline Reagente & Quantidade & Concentração & Marca/código \\
$\mathrm{NaCl}$ & $10 \mathrm{~g}$ & $0,1711 \mathrm{M}$ & Sigma/ S-5886 \\
$\mathrm{KCl}$ & $0,25 \mathrm{~g}$ & $0,0034 \mathrm{M}$ & Sigma/ P-5405 \\
$\mathrm{NaH}_{2} \mathrm{PO}_{4}$ & $1,44 \mathrm{~g}$ & $0,012 \mathrm{M}$ & Sigma/ S-5011 \\
$\mathrm{KH}_{2} \mathrm{PO}_{4}$ & $0,25 \mathrm{~g}$ & $0,0018 \mathrm{M}$ & Sigma/ P-5655 \\
\hline Armazenar $8{ }^{\circ} \mathrm{C}$; Validade: 2 meses & & \\
\hline
\end{tabular}

\section{Solução de paraformaldeído 7,4\% (Estoque)}

\begin{tabular}{lll} 
Reagente & Quantidade & Marca/código \\
Paraformoldeído & $7,4 \mathrm{~g}$ & EMS/ 19210 \\
Água Milli Q $\left(55-60^{\circ} \mathrm{C}\right)$ & $1 \mathrm{~L}$ & --------- \\
\hline
\end{tabular}

Adicionar $\mathrm{NaOH} 2 \mathrm{~N}$ até a solução ficar incolor. Armazenar a $-20{ }^{\circ} \mathrm{C}$; Validade: 6 meses

\begin{tabular}{|lcl|}
\hline & Solução de paraformaldeído 3,7\% (Uso) \\
\hline Reagente & Quantidade & Marca/código \\
Paraformoldeído 7,4\% & $1 \mathrm{~mL}$ & -------- \\
PBS & $1 \mathrm{~mL}$ & --------- \\
\hline Usar no dia & & \\
\hline
\end{tabular}

\begin{tabular}{|lcl|}
\hline \multicolumn{2}{c|}{ Solução de Triton 10\% (Estoque) } \\
\hline Reagente & Quantidade & Marca/código \\
Triton X-100 & $1 \mathrm{~mL}$ & Sigma/ X-100 \\
PBS & $10 \mathrm{~mL}$ & -------- \\
\hline Armazenar a $8{ }^{\circ} \mathrm{C}$; Validade: 6 meses & \\
\hline
\end{tabular}

\begin{tabular}{|lcl|}
\hline & Solução de Triton $0,1 \%$ (Uso) \\
\hline Reagente & Quantidade & Marca/código \\
Triton X-100 10\% & $100 \mu \mathrm{L}$ & -------- \\
PBS & $10 \mathrm{~mL}$ & -------- \\
\hline Usar no dia & & \\
\hline
\end{tabular}

\begin{tabular}{|lll|}
\hline \multicolumn{3}{|c|}{ Solução de Bloqueio } \\
\hline Reagente & Quantidade & Marca/código \\
Soro de cabra & $5 \mathrm{~mL}$ & Gibco/ 16210-064 \\
PBS & $95 \mathrm{~mL}$ & $---------~$ \\
\hline Armazenar a $8{ }^{\circ} \mathrm{C}$; Validade: 1 semana & \\
\hline
\end{tabular}




\begin{tabular}{|lcc|}
\hline \multicolumn{3}{|c|}{ Solução de Hoechst 33342 $5 \mu \mathrm{g} / \mathrm{ml}$ (Estoque) } \\
\hline Reagente & Quantidade & Marca/código \\
Hoechst 33342 & $5 \mu \mathrm{g}$ & Sigma/ B-2261 \\
DMSO & $1 \mathrm{ml}$ & Sigma/ D-2650 \\
\hline Armazenar a $-20{ }^{\circ} \mathrm{C}$; Validade: 6 meses & \\
\hline
\end{tabular}

\begin{tabular}{|lcl|}
\hline & Solução de Hoechst 33342 (Uso) \\
\hline Reagente & Quantidade & Marca/código \\
Hoechst 33342 estoque & $1 \mu \mathrm{L}$ & -------- \\
PBS & $1 \mathrm{ml}$ & -------- \\
\hline Usar no dia & & \\
\hline
\end{tabular}

\begin{tabular}{|lll|}
\hline \multicolumn{2}{c|}{ Solução de DABCO } \\
\hline Reagente & Quantidade & Marca/código \\
1,4-Diazabicyclo [2.2.2] octane & $0,23 \mathrm{~g}$ & Sigma/ D-2522 \\
Tris 0.5M, pH 8.0 & $0,4 \mathrm{ml}$ & Fluka/ 93363 \\
Glicerol & $5 \mathrm{ml}$ & Sigma/ G-5516 \\
Água destilada & $4,6 \mathrm{ml}$ & --------- \\
\hline Armazenar a $8{ }^{\circ} \mathrm{C}$ protegido da luz; Validade: 6 meses & \\
\hline
\end{tabular}

